\title{
Global Warming
}

\author{
John O'M. Bockris \\ Texas A\&M University, Retired \\ Gainesville, Florida, \\ USA
}

\section{Introduction}

The first person to write a paper on the possibility of Global Warming by a mechanism he outlined was Svante Arrhenius (1859-1927) \{National Research Council, 2004\} [1], a renowned Swedish physical chemist who was known particularly by his early ideas on electrolytes and their conductivity.

His idea about Global Warming depended upon the reflected light from the sun that he deduced would be likely to be absorbed by $\mathrm{CO}_{2}$.

The date that this paper was first written indicates that it hardly caused a flutter on future ideas about the methods of obtaining energy. ${ }^{1}$

\subsection{Global warming due to $\mathrm{CO}_{2}$}

The stress upon our dealing with Global Warming, predicted by Arrhenius has been thrust upon the $\mathrm{CO}_{2}$ in the atmosphere that clearly depends on the amount of fossil fuels burned per unit time and therefore reflects the degree by which we use carbon-containing fuels to run our civilization.

Now, one has to understand first of all, the radiation from the sun comes into the earth's atmosphere at wavelengths which correspond to the temperature of the surface of the sun, the emitter, 6 million degrees and the wavelength of the irradiated light from a body of that temperature would be far from that which would get absorbed by the earth's atmosphere. After it has struck the earth, the earth itself absorbs about half of it whilst about half of it is reradiated into space, (Figure 1 \{Robert A. Rohde, 1997\}) from published data and is part of the Global Warming Art project) and is that part of the solar radiation that is partly absorbed by the $\mathrm{CO}_{2}$.

However, this second half of the reradiated light comes at wavelengths that correspond to the temperature of the radiating body, i.e. our earth, so that the reflected light is in a wavelength corresponding to light coming from a body with at temperature of around $300 \mathrm{~K}$.

\footnotetext{
${ }^{1}$ Friedrich Wilhelm Ostwald ( September 1853 - 4 April 1932) [2], a renowned German chemist of the early part of the $20^{\text {th }}$ century, wrote a paper which can be looked at, as parallel to that of Arrhenius. Ostwald was a savvy physical chemist and he saw something else which was parallel to the observations Arrhenius had made somewhat earlier. Ostwald spoke before the German society of scientists pointing out that if we went on burning the fossil fuels we would gradually evolve so much heat that the atmosphere itself would warm.
} 


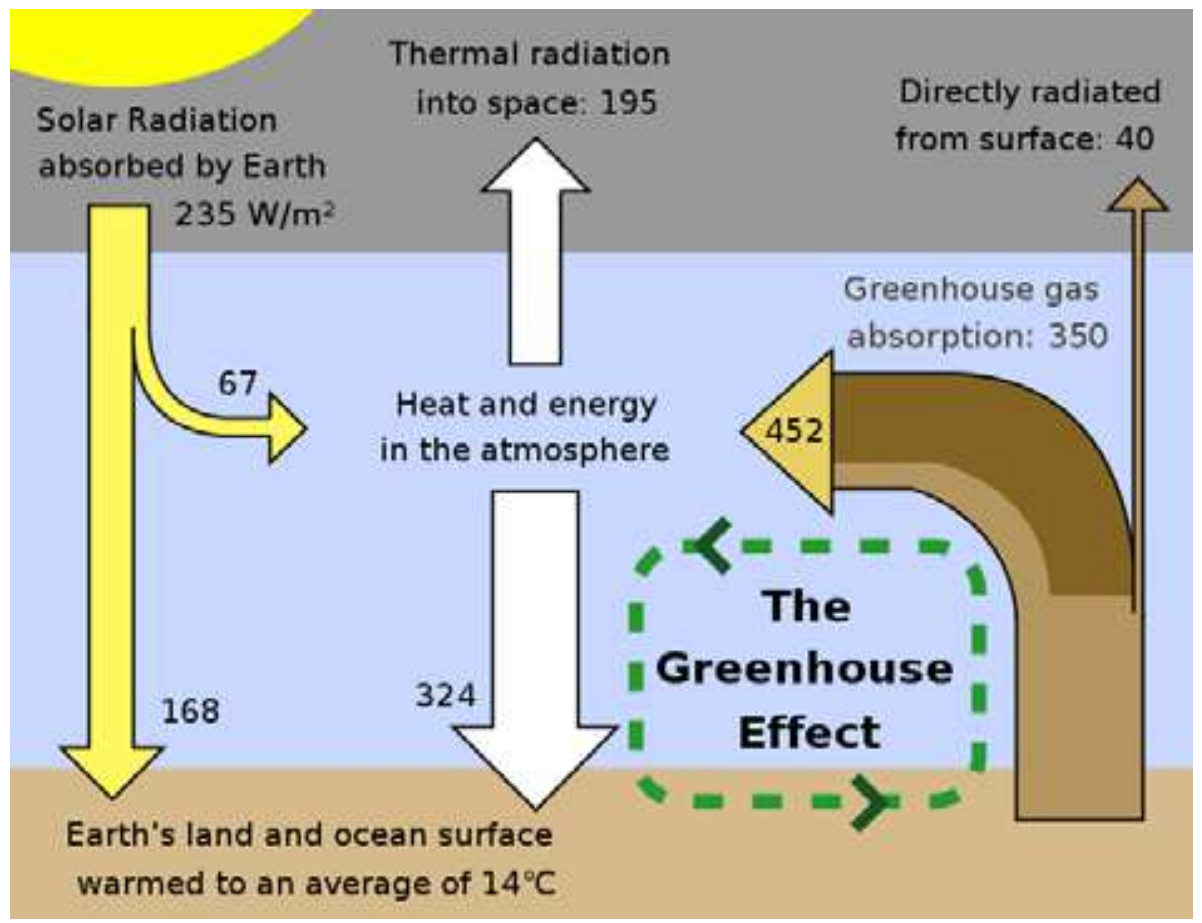

Fig. 1. This figure is a simplified, schematic representation of the flows of energy between space, the atmosphere, and the Earth's surface, and shows how these flows combine to trap heat near the surface and create the greenhouse effect. Energy exchanges are expressed in watts per square meter $(\mathrm{W} / \mathrm{m} 2)$ and derived from Kiehl \& Trenberth (1997). The sun is ultimately responsible for virtually all energy that reaches the Earth's surface. Direct overhead sunlight at the top of the atmosphere provides $1366 \mathrm{~W} / \mathrm{m} 2$; however, geometric effects and reflective surfaces limit the light which is absorbed at the typical location to an annual average of $\sim 235 \mathrm{~W} / \mathrm{m} 2$. If this were the total heat received at the surface, then, neglecting changes in albedo, the Earth's surface would be expected to have an average temperature of $-18^{\circ} \mathrm{C}$ (Lashof 1989). Instead, the Earth's atmosphere recycles heat coming from the surface and delivers an additional $324 \mathrm{~W} / \mathrm{m} 2$, which results in an average surface temperature of roughly $+14^{\circ} \mathrm{C}$. Of the surface heat captured by the atmosphere, more than $75 \%$ can be attributed to the action of greenhouse gases that absorb thermal radiation emitted by the Earth's surface. The atmosphere in turn transfers the energy it receives both into space $(38 \%)$ and back to the Earth's surface $(62 \%)$, where the amount transferred in each direction depends on the thermal and density structure of the atmosphere.This process by which energy is recycled in the atmosphere to warm the Earth's surface is known as the greenhouse effect and is an essential piece of Earth's climate. Under stable conditions, the total amount of energy entering the system from solar radiation will exactly balance the amount being radiated into space, thus allowing the Earth to maintain a constant average temperature over time. However, recent measurements indicate that the Earth is presently absorbing $0.85 \pm 0.15 \mathrm{~W} / \mathrm{m} 2$ more than it emits into space (Hansen et al. 2005). An overwhelming majority of climate scientists believe that this asymmetry in the flow of energy has been significantly increased by human emissions of greenhouse gases. 
Now, the shape of the solar spectrum (see Figure 1) i.e. the plot of intensity against wavelength depends sharply upon the temperature of the emitter. The solar light incoming, as we have said, does not overlap the absorption bands of the $\mathrm{CO}_{2}$ in the atmosphere. Conversely however, the radiation coming from the 300-degree emitter, our earth does indeed contain bands that correspond to those in which $\mathrm{CO}_{2}$ absorbs. (Figure 2 \{Robert $\mathrm{A}$. Rohde, 2008\}); Figure 3 \{Tapan Bose \& Pierre Malbrunot, 2006\}).

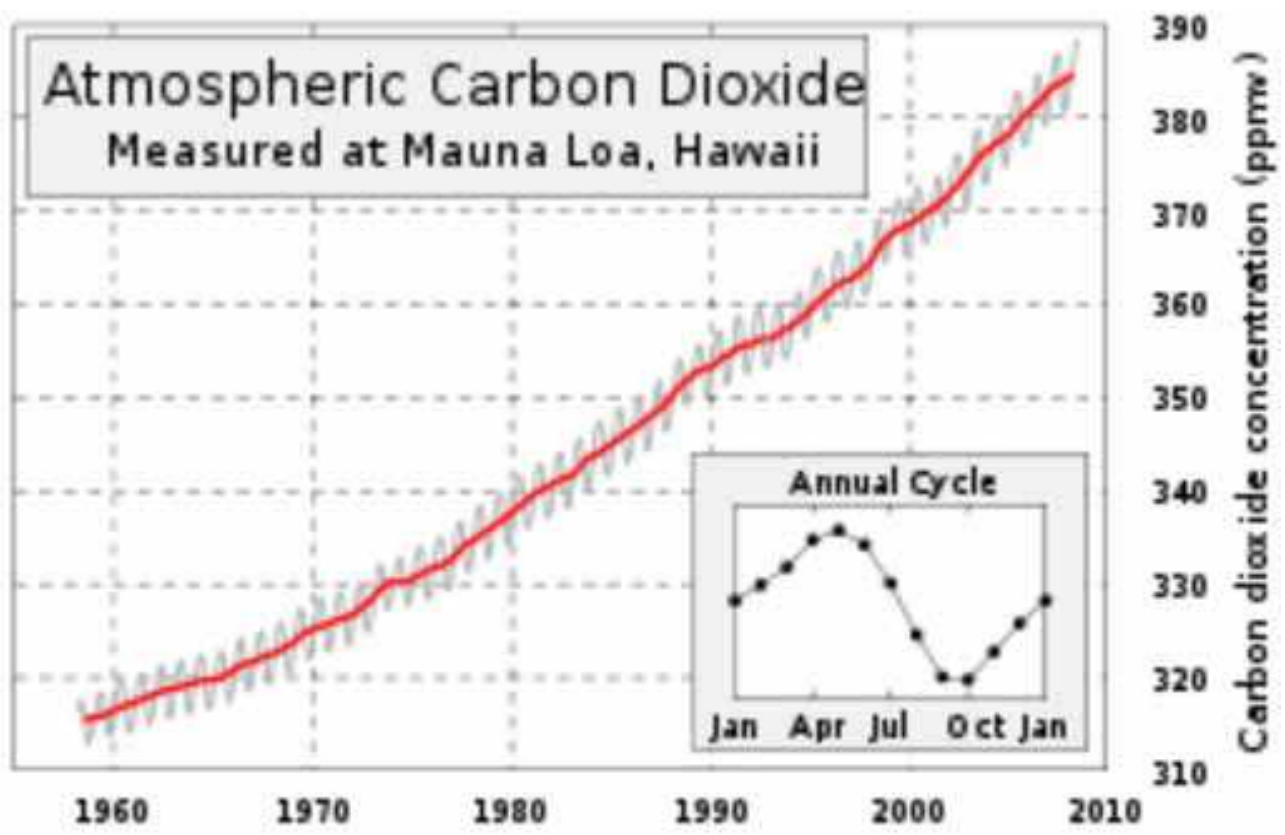

Fig. 2. The Keeling Curve of atmospheric $\mathrm{CO}_{2}$ concentrations measured at Mauna Loa Observatory. This figure shows the history of atmospheric carbon dioxide concentrations as directly measured at Mauna Loa, Hawaii. This curve is known as the Keeling curve, and is an essential piece of evidence of the man-made increases in greenhouse gases that are believed to be the cause of global warming. The longest such record exists at Mauna Loa, but these measurements have been independently confirmed at many other sites around the world. The annual fluctuation in carbon dioxide is caused by seasonal variations in carbon dioxide uptake by land plants. Since many more forests are concentrated in the Northern Hemisphere, more carbon dioxide is removed from the atmosphere during Northern Hemisphere summer than Southern Hemisphere summer. This annual cycle is shown in the inset figure by taking the average concentration for each month across all measured years. Own work, from Image:Mauna Loa Carbon Dioxide.png, uploaded in Commons by Nils Simon under licence GFDL \& CC-NC-SA ; itself created by Robert A. Rohde (2008) from NOAA published data and is incorporated into the Global Warming Art project. Permission is granted to copy, distribute and lor modify this document under the terms of the GNU Free Documentation License, Version 1.2 or any later version published by the Free software Foundation; with no Invariant Sections, no Front-Cover Texts, and no Back-Cover Texts. A copy of the license is included in the section entitled "GNU Free Documentation license" 


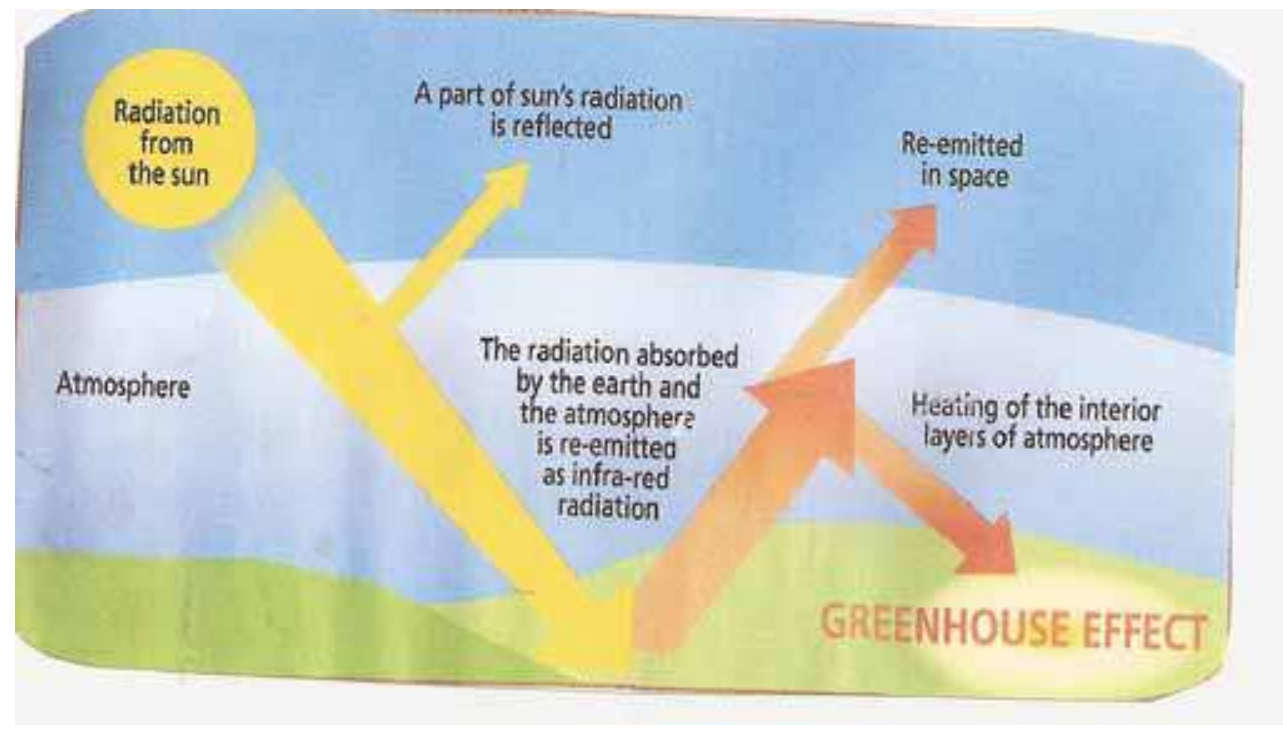

Fig. 3. From Tapan Bose and Pierre Malbrunot, et al, Hydrogen: Facing the Energy Challenge of the 21st Century, John Libby Eurotext, UK, December 2006, page 17.

It is possible to look at Global Warming in a mathematical way and that is exactly what the Turkish-American scientist, Veziroglu \{Veziroglu, Gurkin, and Padki, 1989\} with colleagues did in a paper to which we shall refer later on when considering contributions which could be made for the earth's temperature by other gases, e.g. methane [3].

Figure 2 shows the temperature rise in the atmosphere and it can be seen that the increase of the $\mathrm{CO}_{2}$ with time has been of an exponential character.

The anxiety that has been produced in some citizens, who conclude that the earth will become too hot to sustain human life, can now be looked at with the facts. The first reaction is perhaps a sigh of relief. It's not going to happen at once but there are societies that would be sensitive in respect to the maintenance of life, and even due to a further rise of, say, $5{ }^{\circ} \mathrm{C}$. (See section on methane.)

Such a country is Saudi Arabia, and also the surrounding countries in the Middle East. The government of Saudi Arabia has made a law there that should the surrounding temperature increase got to more than $50{ }^{\circ} \mathrm{C}\left(122{ }^{\circ} \mathrm{F}\right)$, then as far as is possible: no traffic, no machines operating, which produce significant heat. Heat bursts at $40{ }^{\circ} \mathrm{C}$ were experienced in France in 2007 and more than 1000 did not survive, but these people were above 75 years in age.

Looking then at Figure 4 \{Jones, P.D. and Moberg, A., 2003\}, it is seen that we have, at 2010, that the increase has already exceeded $1.4^{\circ} \mathrm{F} .^{2}$

\footnotetext{
${ }^{2}$ The actual mechanism of the heat rise of the atmosphere comes through an intermediate stage when the excited $\mathrm{CO} 2$ molecules, absorbing the reflected light, collide with very many surrounding nitrogen and oxygen molecules of the air and transfer some of the excited energy in the vibrational bands to the translational energy of the air molecules. This means that they in turn travel faster, i.e. their molecular energy is increased and that in turn is the essence of Global Warming.
} 


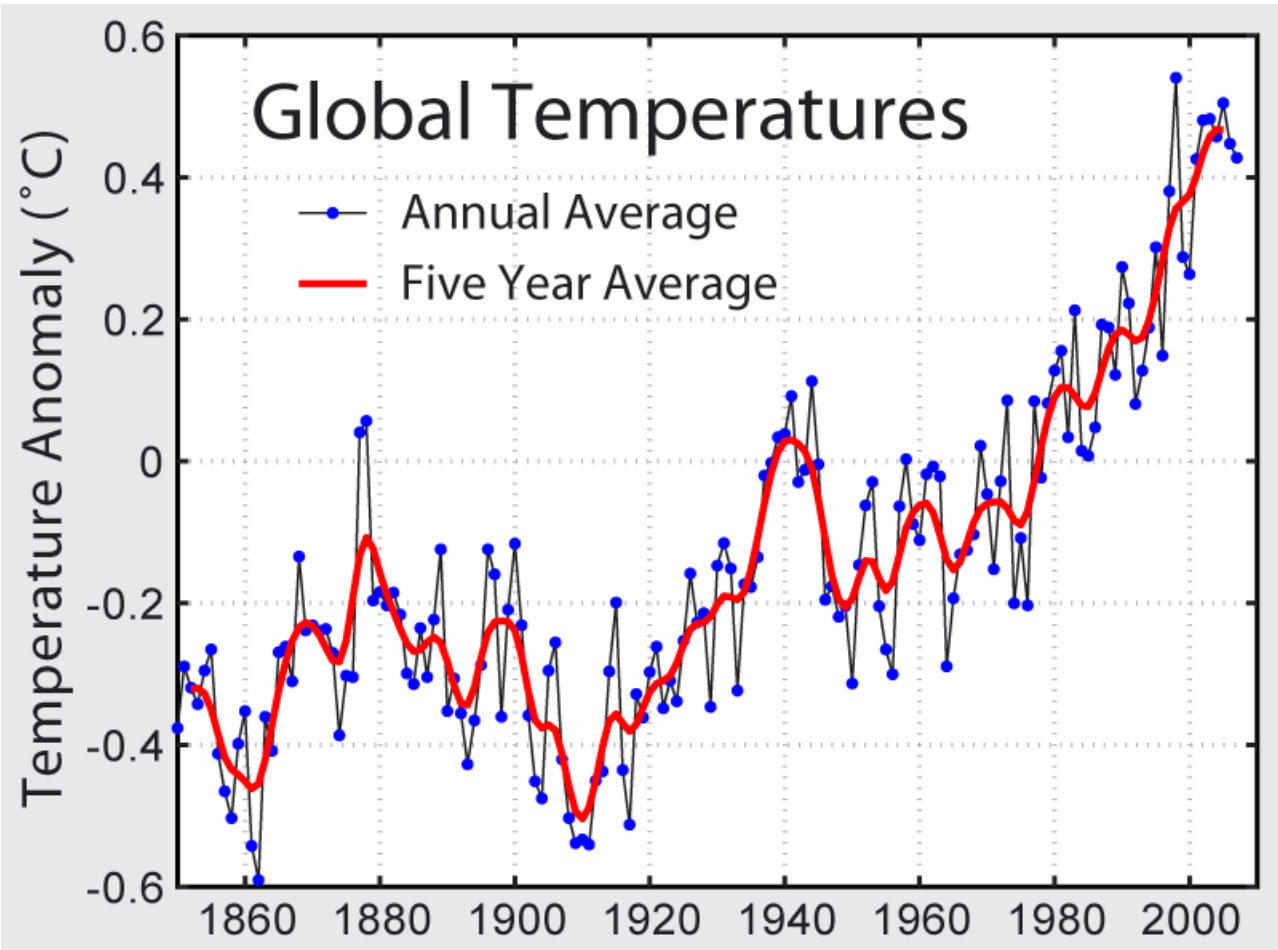

Fig. 4. This figure shows the instrumental record of global average temperatures as compiled by the Climatic Research Unit of the University of East Anglia and the Hadley Centre of the0 UK Meteorological Office. Data set TaveGL2v was used. The most recent documentation for this data set is Jones, P.D. and Moberg, A. (2003) "Hemispheric and largescale surface air temperature variations: An extensive revision and an update to 2001". Journal of Climate, 16, 206-223.

Many interested in this area of Global Warming would like to know how many years do we have before an unattended problem becomes too much for us [3]? Now, the answer to such a question depends upon how citizens react to very high atmospheric temperatures. $50^{\circ} \mathrm{C}$, the Saudi limit, is 123 o $\mathrm{F}$ and that is not an unknown temperature in the United States, in such places as Death Valley in California. However, the prospect of living under such temperatures seems to be out of the question.

Now, to answer the question, when will it get too hot, is difficult for two reasons. First of all (and this is easily understood) the answer can only be given for a given region of earth, or at least a section of a large country such as the USA. Indeed, if one moves a thousand miles north into arctic Canada, one can see some years of happiness there, occurring during the later stages of Global Warming because Canada, too, would be a gigantic country were it not for the fact that most of it is at present frozen. ${ }^{3}$

\footnotetext{
${ }^{3}$ It is possible to treat the degree of curvature in Figure 2 and we would do better with an equation for a relation which has curvature in it were we to have a few more points.
} 


\section{Atmospheric Concentration of Carbon Dioxide, 1000-2007}

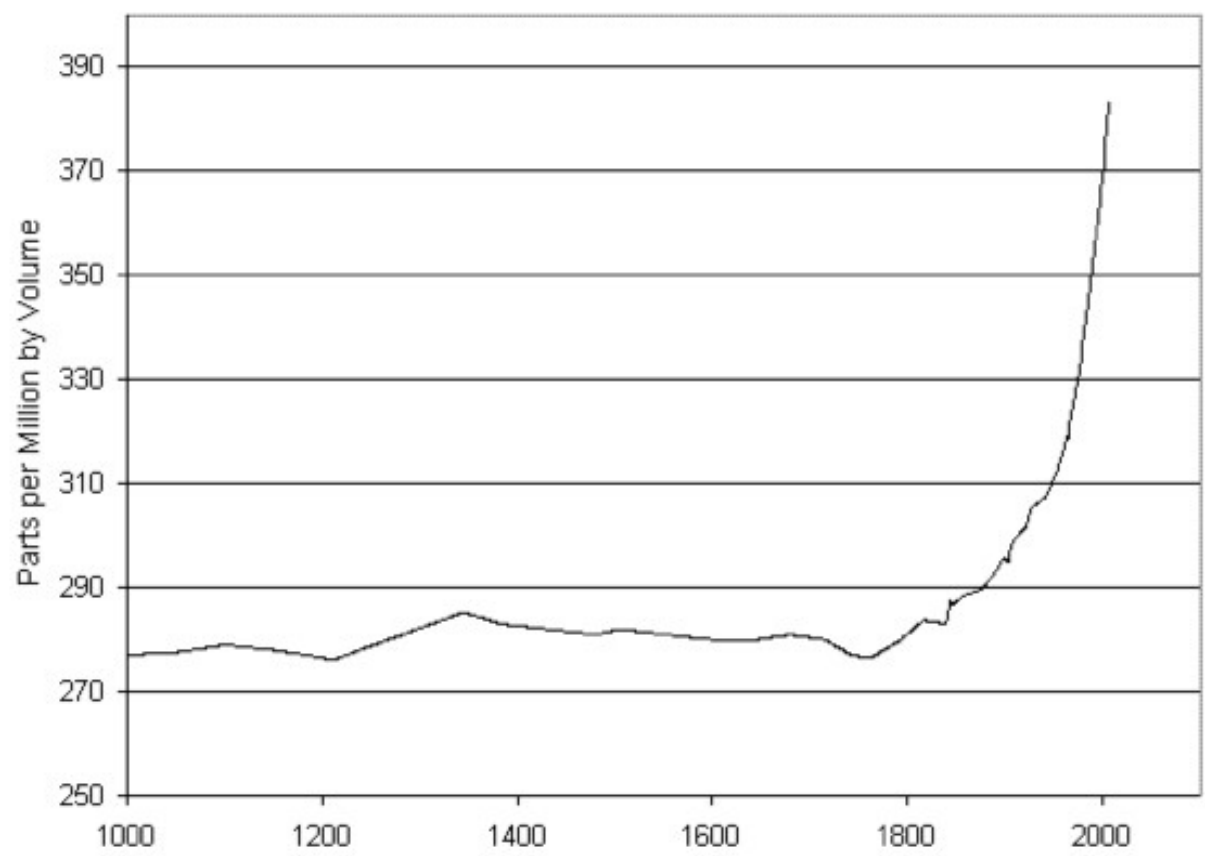

Source: NOAA, ORNL and IPCC

Fig. 5. $\mathrm{CO}_{2}$ over 1000 years. The Hydrogen Economy. Opportunities, Costs, Barriers and R\&D Needs. National Research Council and National Academy of Engineering, National Academies Press, Washington DC, 2004 [4].

\subsection{Global warming due to the presence of methane in the atmosphere?}

In most articles on Global Warming, the entire problem is put on $\mathrm{CO}_{2}$, but this may be too optimistic because there is another gas that is gradually increasing in our atmosphere and it is the simple molecule methane, $\mathrm{CH}_{4}$.

Now, at present, 2010, there is a contribution of methane to the temperature of the atmosphere, which at first seems quite low, $8 \%$.

However, in considering this figure, one has to understand something after which methane can be looked at differently $\{\mathrm{H}$. Blake, 2010\} [5]. Thus, the individual methane molecule absorbs 23 times more of the reflected energy from the sun than the $\mathrm{CO}_{2}$ molecule when both, in our atmosphere, get reflected light upon our surface.

In other words, methane, $\mathrm{CH}_{4}$, is a more dangerous molecule than $\mathrm{CO}_{2}$ and the only reason why there has been so much discussion of $\mathrm{CO}_{2}$ and almost no public discussion about methane is that hitherto the concentration of methane in the atmosphere has been small. 
Now, there is a reason why we might have to be more concerned with methane for not only its absorptive power, 23 times greater than that of $\mathrm{CO}_{2}$, but also there is a reason whereby methane could significantly increase its concentration in our atmosphere.

Estimates have been made of the total amount of methane that may be in fact hidden from us at the moment because it is largely in the tundra in the northern climes of the world \{National Oceanic and Atmospheric Administration, 2007; and H. Blake, 2010\} [4,5].

This tundra is dark-colored vegetation that is met in the far north and it is inside this that the methane at present is largely hidden. This area of the world is still frozen and the methane is in the frozen tundra \{University of Toronto, Chemistry Department, 2008\} [6].

Predictions have been made (but I must caution they are not reliable) about the total amount of methane that may be hidden in the tundra \{BBC News, 2006; N. Shakhova \& I. Semiletov, 2007; University of Cambridge Press, 2001; and Walter et al., 2006\} [7, 8, 9, 10, 11]. The figure I have obtained is 380 billion tons and were this huge amount of methane to be released, the question is what would happen to it?

One way of looking at this is to observe that methane is lighter per molecule than oxygen, nitrogen or $\mathrm{CO}_{2}$ and therefore, according to the Archimedean principle, it should rise and eventually escape our atmosphere into space $\{$ http:/ / globalwarmingcycles.info/, 2010\} [12]. This is comforting but then we come across a disagreeable fact. $\mathrm{CO}_{2}$ is heavier than the other molecules in the atmosphere and if Archimedean principles were the only thing to consider, $\mathrm{CO}_{2}$ would sink among the other constituents in the atmosphere until it blanketed the earth down low on us. This would not be good at all. Luckily, our measurements show that $\mathrm{CO}_{2}$ is evenly distributed for at least 10 miles up.

Thus, we cannot complacently expect the methane to escape upwards. What is it that makes the $\mathrm{CO}_{2}$ be uniformly distributed?

The answer the climatologists give us is that as one goes upwards from the earth, there is increasing turbulence. The temperature gets colder and the winds greater, so the $\mathrm{CO}_{2}$, jostled around in its collisions with the other molecules until the affect of the Archimedean drop becomes negligible. Indeed the $\mathrm{CO}_{2}$ has been there for much of the earth's life, because the green plants and their growth depend directly upon it.

The principal thing that I tried to draw out of DOE was the rate of the movement of the ice line towards the north. It's clear that it's retreating, but what is the rate of that retreat for it will eventually melt the frozen tundra?

Some discussions I had with a senior expert from the Washington DOE \{Private communications, 2009\} [14], who warned me that I should be cautious in stirring anxiety. I decided that the only thing I could do was to assume that eventually, be it in one year or ten, that the tundra were going to melt and I wanted to know what would happen then Private communications, 2009\} [13].

Thus, to assume the entire 380 billion tons would all go to the atmosphere was an extreme but unlikely assumption. The tundra is not growing on the surface of the earth but deep inside it as well.

Further, to get the 380 billion tons estimated was to assume that the whole tundra was inundated with methane now whereas the creation of methane is a biological reaction going on at a speed of which we know little.

It is not that the 380 billion tons that may be there right now might hit us immediately. The question is how much methane is being created inside the tundra and what will be the rate of that growth compared with the time at which the tundra will melt. 
The truth is the methane in the tundra is a possible threat \{D. Roberts et al., 2007\} [15]. We should be aware of it and look at calculations with certain assumptions. Certainly the maximum likely effect is dire, but its severity is unlikely to be realized.

\subsection{Attempted calculation of the maximum effect of methane on the world's temperature}

I made a number of positive assumptions in order to get the worst that the assumptions predict. The first assumption is that the 380 billion tons of methane is a number that may become reality in our time.

A second assumption is: will the distribution of methane, were it to mix with air, be uniform and how long would it take to become so? At first I assumed that the methane would spread along the near earth surface and then diffuse upwards. The figure I got was four years, for the methane to diffuse up 10 miles that is around about the extent of $90 \%$ of our atmosphere. (Some information on the albedo can help in estimating a uniformity of the mixture of gases (Figure 6) \{Dar A. Roberts a, Eliza S. Bradley a, Ross Cheung b, Ira Leifer c, Philip E. Dennison d, Jack S. Margolis, 2006\}.)

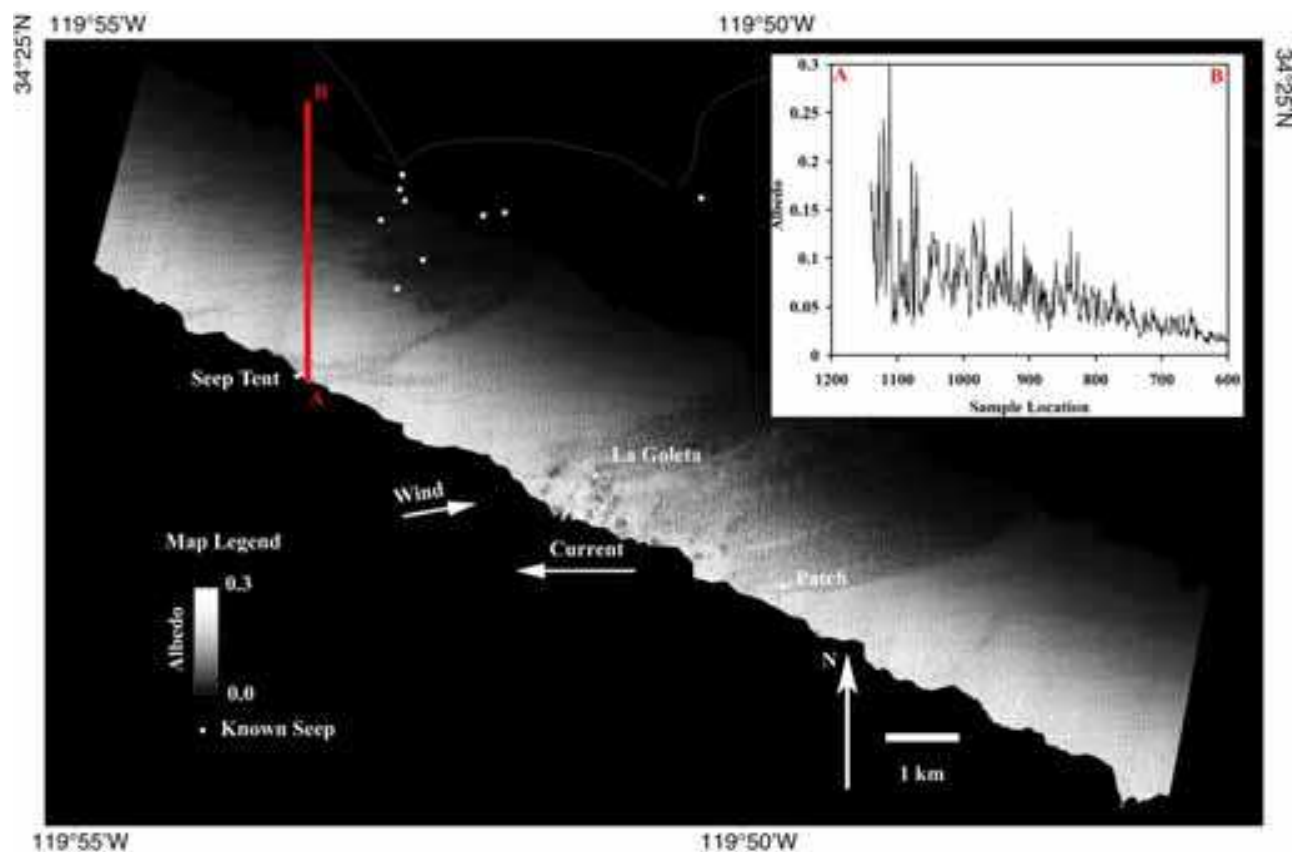

Fig. 6. Estimated albedo for 6 August 2007 Run R04. The location of the coast is marked in very faint green. Wind direction, from a coastal weather station (www.geog.ucsb.edu/ideas) and codar-derived currents, measured by the Interdisciplinary Oceanography Group (http://www.icess.ucsb.edu/iog/archive/25) are marked. Inset shows north-south albedo transect (red line) that includes the Seep Tent area. Some named seeps are marked by white squares [15] 
However, I abandoned this approach because, of disturbances which interfere grossly with the condition diffusion requires. It's going to spread further and faster than that, egged on by the Archimedean thrust to rise but mixed up with wind and temperature changes it will meet.

I therefore assumed uniformity and of course it's a simple calculation to find out the concentration per liter of methane if the whole 380 billions tons were uniformly distributed in the 10 miles (upward in our atmosphere).

With these limiting assumptions then, I turned to the mathematics which Veziroglu \{Veziroglu et al., 1989\} and his associates produced and fitted my assumptions into his calculations [3]. What the Veziroglu paper actually calculates is the temperature change in the atmosphere and so far as the $\mathrm{CO}_{2}$ changes its concentration, climbing slowly as we show in Figures 2 and 4. So I assumed one could equate a single methane molecule to $23 \mathrm{CO}_{2}$ molecules. Of course this simplifying assumption made it easy to get results from the Veziroglu theoretical formulations on $\mathrm{CO}_{2}$ and the result I got, with all the positive assumptions I had made, was $6^{\circ} \mathrm{C}$ in ten years \{Veziroglu, Gurkin, and Padki, 1989\} [16].

I asked myself then when it would begin a decline in our atmosphere and was there any end to it, and here I took to a Professor in Meteorology at the University of Florida, who seemed knowledgeable in discussions of methane and the dynamics of its presence in the atmosphere.

Qualitatively, his view was that there was a conflict between the Archimedean rise idea and the wind and temperature disturbance idea. He brushed aside the $\mathrm{CO}_{2}$ and the fact it has remained stable and uniform for millennia. He said he had made a calculation which suggested that the best model would be to assume a quick distribution of the methane after the tundra had melted and then he thought that ten years would be about the time at which the tendency of the light methane molecule would escape into space.

For a moment, let us consider that my 6-degree calculation from Veziroglu's theory has value.

One can see at once there were some places on earth that would be stricken. Imagine what it would be like in Saudi Arabia at $123^{\circ} \mathrm{F}$. Now, add to that, $6^{\circ} \mathrm{C}$ or c. $12^{\circ} \mathrm{F}$, and you will see that the inhabitants of Saudi Arabia could be really threatened if the temperature rose as I think is possible.

Of course it wouldn't be only Saudi Arabia but their surrounding countries, too. This is something that they have to confront (and they have the money to launch a more accurate investigation than the rough one I did in using what DOE would give, together with the calculations of Veziroglu et al \{Veziroglu, Gurkin, and Padki, 1989\} [17].

\subsection{Disagreement as to the cause of global warming}

Among those who have studied the $\mathrm{CO}_{2}$ theory of Global Warming, may be somewhat surprised to know that there is a group of people (are they scientists?) in our community who disagree that $\mathrm{CO}_{2}$ is the main cause \{Edward Townes, 2007\} [18].

This has always been the case from the beginning of concern about Global Warming way back in the 1970's.

The argument of the anti- $\mathrm{CO}_{2}$ group begins by pointing out that ice cores taken deep into the earth show that the temperature of the earth has varied greatly over thousands of years. The opponents of this theory point to much greater variations in the earth's temperature 
than we see at the moment. Some anti-reactions will occur on earth that will compensate the temperature rise we are now seeing and it's better to find out the true cause of the present rise before we put too much money into fighting it \{B. Pelham, 2009\} [19].

Another part of the strength of the anti- $\mathrm{CO}_{2}$ group is largely from the public itself. The distressing truth is that the majority does not believe in Global Warming and that naturally this affects the vote in congress when it comes to research and money spent in that direction. The answer is that the change is very slow but indeed it is faster than the changes in the past (the really big changes) to which people refer. The idea that there is "no change really"

\section{Sources unencumbered by $\mathrm{CO}_{2}$}

The general presentation of this treatment of Global Warming is to point out that there are a total of six different sources of energy, some of which we could develop and rely upon. They're inexhaustible and clean, and it's easy to profit from them, compared to gasoline that comes from oil buried in the earth and has to be processed, but also damages the environment. The first thing then is to present clean sources of energy. They are mainly wind \{J. Usaola, E. Castronuovo, 2009; C. Osphey, 2009; H. Green, 2008\} [20, 21, 22], solar, and enhanced geothermal.

Then having given the stated main sources on each of them, I go on to treat several others $\{\mathrm{J}$. Bockris, 2009\} [23], for example, the enhanced geothermal energy ("Hot Rock Geothermal"), which could be a major source of energy, together with the less realized ones, the massive development of tidal energies and et cetera \{C. Osphey, 2009; H. Green, 2008\} [21, 22].

Later on in the article you will find there is a discussion of the mediums because each of these main energy sources $\{\mathrm{J}$. Bockris, 2009\} [23] must have a partner which is in a form of energy which can be spread and be introduced into households and factories \{J. Bockris, 2009\} [23].

Among the discussion of these mediums there is an introduction to a concept, the power relay satellite. German inventions of World War II but never developed. It's development concerns diurnal difficulties of solar light and it would be possible, if we had a sufficient collection of solar energy, - and the Australian Continent is such \{B. Roberts et al, 2007\}[24], to spread this solar energy and operate not only within a few tens of miles of the original source, but to anywhere in the world and therefore as the times of darkness are different in different parts of the world, but varying the opposite direction to the periods of light, it should be possible in principle to bring solar energy \{J. Bockris, 2009\} [25] to anywhere in the earth and thus counteract its principal hazard \{J. Bockris, 1975\} [26].

\subsection{General philosophy of dealing with global warming}

The general philosophy in this article in dealing with Global Warming is to take the attitude that the principal cause of Global Warming; the influx of $\mathrm{CO}_{2}$ into the atmosphere, must be reduced towards zero. This therefore is only a scientific matter in respect to what comes after \{N. Muradov, N. Veziroglu, 2009\} [27]; because of course there is no point in shutting off the gasoline unless we replace it. The task is large so that is seems reasonable that there should be a central authority for the development of replacement energy systems for the fossil fuels.

As to the fossil fuels, - coal, oil, and natural gas, - I believe that what has to be done with them, - a very political matter, - is arranged between the government and their very wealthy owners, for the government has the right to tax their products. 
Thus, in the following pages we are going to review our energy future in two ways $\{\mathrm{J}$. Bockris, 2009\} [28]. Firstly, we are going to think that discretion is the better part of valor in respect to dealing with the oil companies. It is a matter that the government has to do and the president of our country has to be careful to be sure that special interests do not have any part in the decision as to when and how the fossil fuels will be made too expensive.

It will be necessary to allow time to build across the country the replacement energy systems of wind, solar, and hot rock geothermal.

There are various estimates on how quickly the change can be made. The Chinese government has made public their plan to change their transportation system in eleven years.

Let us adopt a pathway that is a little less demanding and decide that we are going to change over in twenty years with the extension to thirty years being acceptable, but not joyfully.

We will begin then by illuminating here first wind energy because it is the lowest cost. Then after we have the best source for our part of the world, other matters such as the transfer of energy over long distances, - will come in.

\subsection{Wind:}

Many who are told that wind may be part of our future energy supply find it hard to believe because wind is sporadic, and cannot be relied upon at any particular time or place.

Hence, it is important to understand the concept of averages when applied to wind energy. The usual thing is to look at the average or the cubes of the reported wind velocity taken daily. This gives the effective wind speed for the year, and the cube of this is the usual quoted figure. It's important not to take the cube of the average of the wind energies, but rather the average of the cubes. (See Equation 1 below.)

Another important preliminary to discussion of wind energy is wind belts. Of course, there are minor variations from year to year of the wind velocities in a given location, but on the whole if the average of the cubes is taken every year for a number of years, and the average of this figure is used in planning, such results will be effective.

In the USA, the part of the country for wind belt location is in Middle USA., north to south. The Wind Energy Association publishes maps of wind belts (DOE does the same). To show the sensitivity of a wind generator to values of $\mathrm{v}$, the wind speed, one can take the example of going from $15 \mathrm{mph}$ to $18 \mathrm{mph}$ (apparently a small difference), but when one takes the cubes, it turns out that $18 \mathrm{mph}$ is some 75 percent over $15 \mathrm{mph}$ as the rates at which energy can be gathered.

\subsection{Wind to electricity}

The transfer of wind energy to electricity is carried out by using the combination of the energy of a rotating series of blades in the path of the wind, coupled with an electricity generator built into the apparatus. The axle of a rotor may weigh many tons \{J. Usaola, E. Castronuovo, 2009\} [20].

If untreated the supply of electrical energy from a wind generator would vary with the cube of the speed of the wind, and the occasional wind gusts. In order to avoid irregularity of supply, most wind generators are fitted with electronic devices that smooth out the supply in terms of volts. Powerful wind gusts, however, are a different matter and there is research to be done on how to capture the considerable energy that does come in gusts where the $\mathrm{v}$ may go to six to ten times the average velocity $\{J$. Usaola, E. Castronuovo, 2009; C. Osphey, 2009\} [20,21]. 

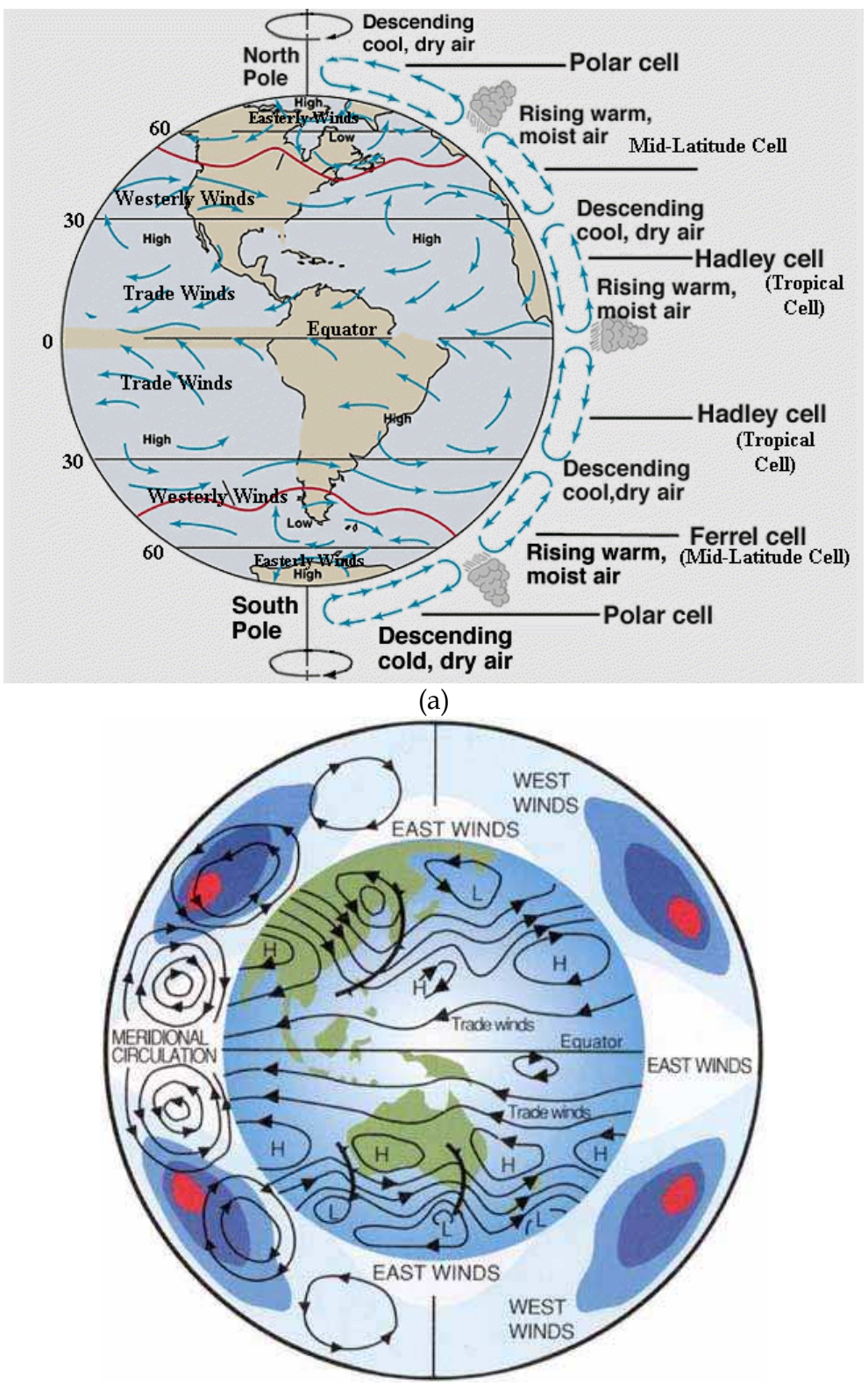

(b)

Fig. 7. a. Wind map of the USA

http://www.cnsm.csulb.edu/departments/geology/people/bperry/geology303/_derived /geol303text.html_txt_atmoscell_big.gif b. Wind maps of northern regions.

http:// mabryonline.org/blogs/woolsey/images/global\%20winds\%202-1.jpg 


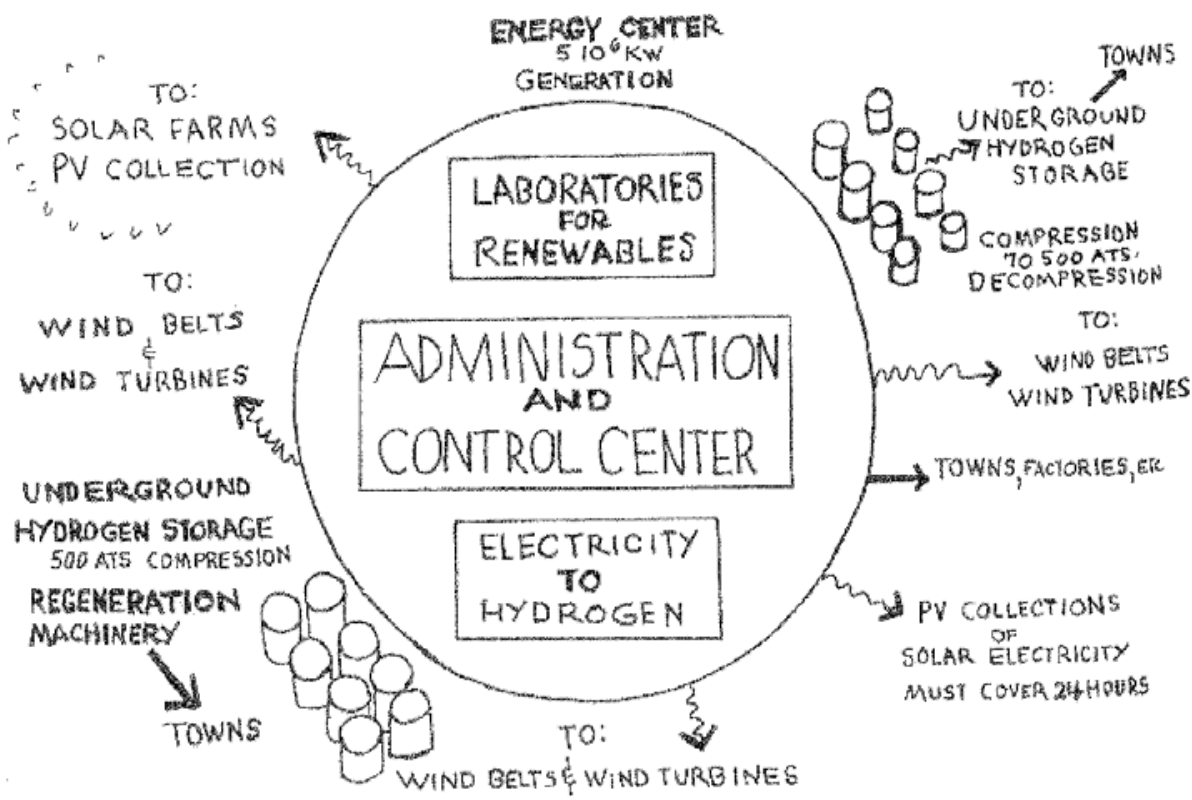

Fig. 8. Energy Center, J. O'M. Bockris Original, 2009

Many of the earlier wind generators often broke down in gusts, having been built to sustain only the average wind energy in a given location.

An energy center (See Figure 8 above) has to be made if wind is to be used on a massive scale for the supply of towns. The idea here is to place the wind generators in a circle surrounding the energy center with no greater distance than 50 miles between generator and center.

A possible energy center is shown in the Figure 8 above.

The Center contains apparatus for mixing various incoming electrical energies from the wind generators. These are then divided into supply lines that go out from the wind (or solar) center to surrounding towns. Details of arrangements will depend upon the population density of the area, however, the center may supply only large towns of say 1 million in population or larger.

Then, these supply towns would act as sub centers for other smaller towns. So, a one million people town may branch out to supply, say, ten smaller towns, down to the supply of villages from nearby larger house groups.

In large cities such as New York, several centers would have to be used.

After much research the optimal shape of wind generators has been reduced to two, $\{\mathrm{H}$. Green, 2008 \} [22] (see 9A and B). The main one is that well known one, horizontal propeller and such wind generators are found to last about fifty to 100 years. However, there is another type of wind generator as shown in the Figure $9 \mathrm{~B}$ which is called a vertical axis generator, and it can be seen that the wind is gathered in the cusp type shape of half the blades, and these then rotate around the vertical shaft, bringing in to face the wind, a sloping area of the other half type cusps so that when this swings around to face the wind, the pull on it is much less than when the wind is being collected in the cusp type part of the generator. 


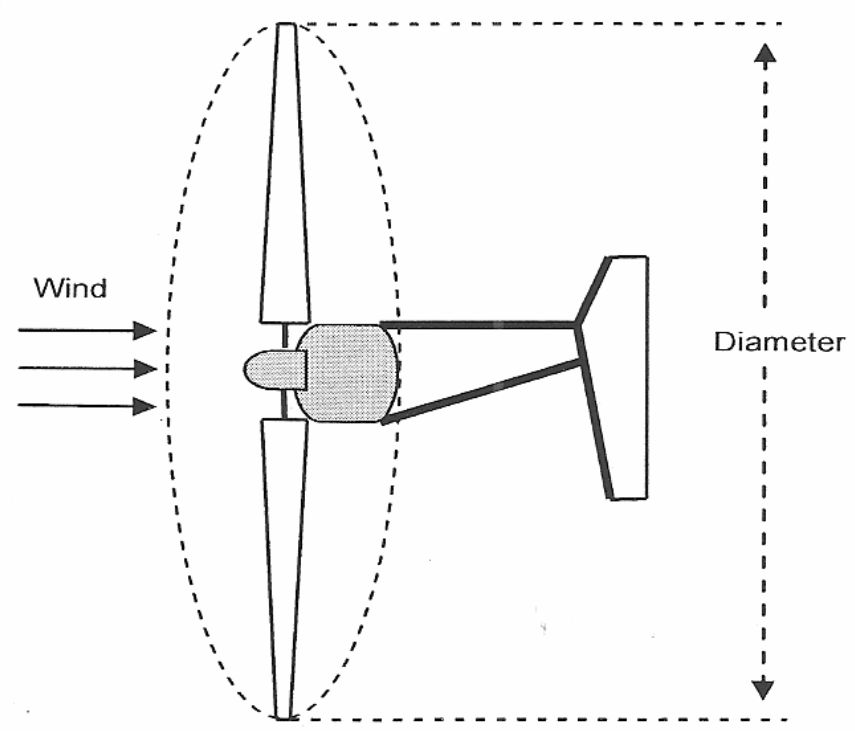

Propellor-type Rotor

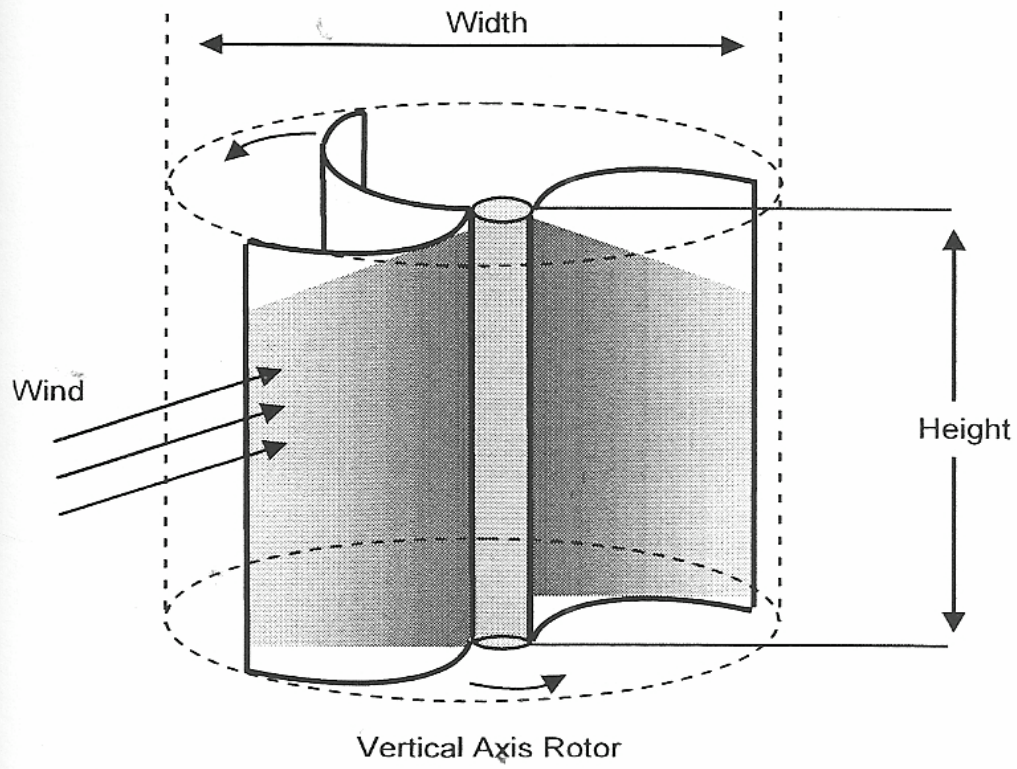

Fig. 9. A \& B: \{Iowa Energy Center, 2006\} 
It might be thought that four blades would increase the use of a single shaft but the manufacturers tell us that the material and machinery for accommodating multi-blade generators do not pay.

Wind generators can also be set up to work at sea. At first sight, there is much advantage in this because winds at sea tend to be greater and even up to twice times the winds on land. The reason is the lack of obstructions to the wind that occur on the ground.

However, there are compensating factors that make the positioning of the generators at sea, a questionable matter. Firstly, the construction of the actual generator has to be strengthened because of the higher intensity of the winds. This strengthening must include balancing weights underwater as shown in Figures 10 and 11.

Another negative feature of the wind borne generator is the cost of delivering the energy back to land. This can be done by cable but in extreme cases, ships collect the product.

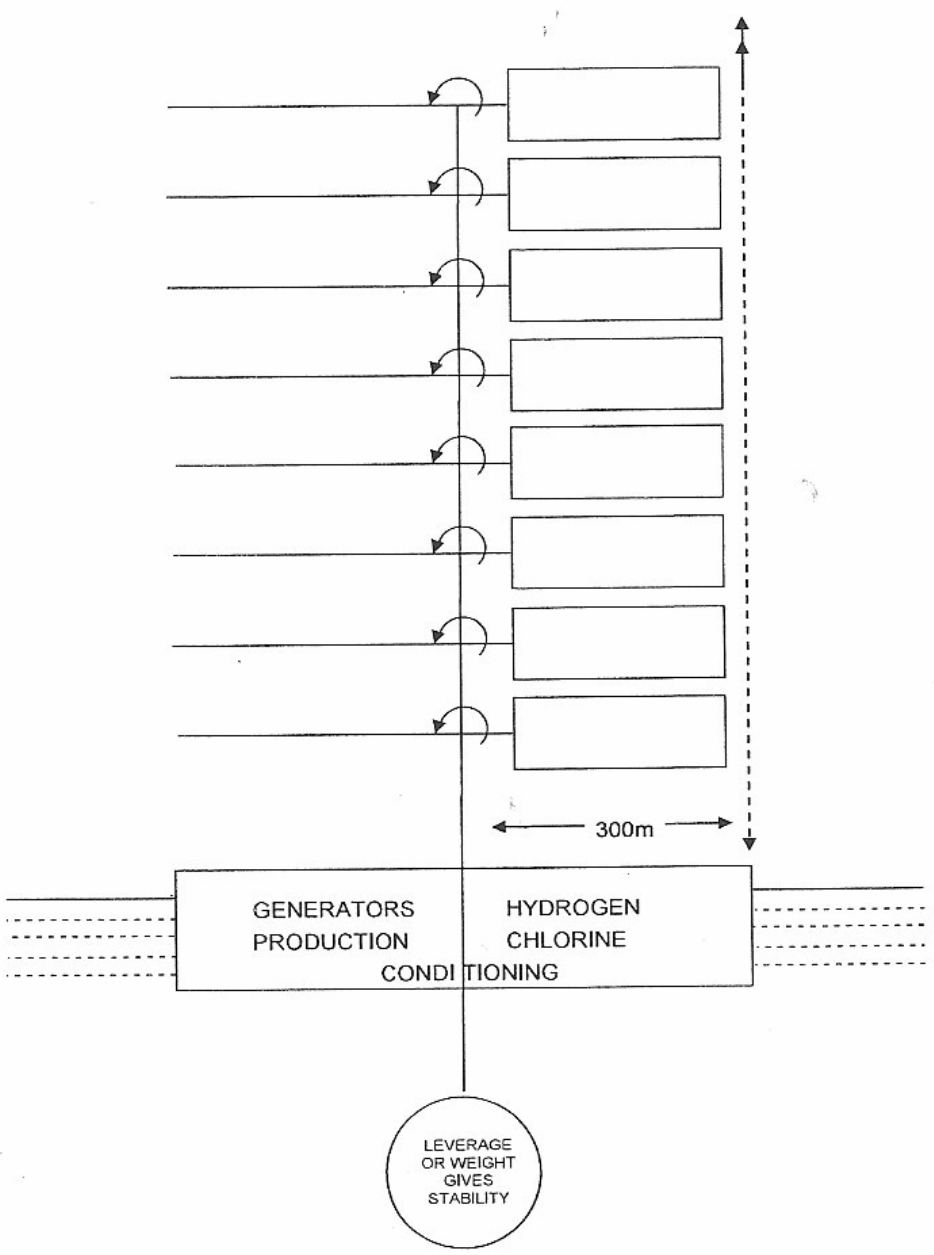

Fig. 10. A possible arrangement for a sea-borne generator. \{J.Bockris, 1975\} 


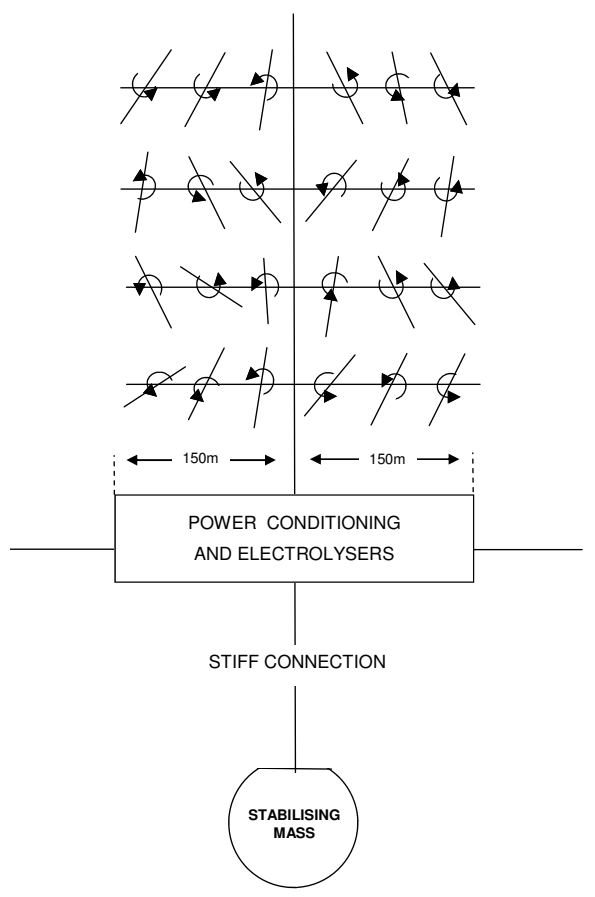

Fig. 11. An alternative arrangement for a sea-borne generator. \{J.Bockris, 1975\}

One of the newer concepts that have been introduced into wind generator construction is the magna lev concept, i.e. the shaft of the generator that of course normally is fitted into a socket that causes friction but is lifted from the socket contact by electro-magnetism. This concept is not commercial, but the designers say the lessening of the cost of the wind is up to $10 \mathrm{x}$, and if this can be verified in practice, it is obvious that it will be introduced into newer generators which make wind even lower cost.

One may be forced to go to sea, where there is always plenty of room, - and more wind. ${ }^{4}$

\subsection{A theory of wind generation of energy at speeds of up to $20 \mathrm{mph}$}

Wind generators have not been considered on a massive scale such as that which will be needed for the supply of towns. However the economic attraction of the wind generator is great on an economic basis because the owner who receives his generator can start using it to produce a profit within weeks of delivery.

With several renewable energies, there may be preliminary building to be made that could delay the receipt of profit by the owner for years.

Of course, a study has to be made firstly about the detailed conditions of wind in the place considered, and this must include not only the minimal economic velocity of the wind

\footnotetext{
${ }^{4}$ It may be important to lower the cost of wind generators, which at the moment on land, produce energy as low as $\$ .03 \mathrm{c} / \mathrm{kWh}$. Wind as a main source of energy in the future must face the hot rock geothermal situation and therefore lowering it would be needed.
} 
average, about $12 \mathrm{mph}$, but also the question of wind gusts and whether they would be a threat to the stability of the wind generators $\{H$. Green, 2008; J. Bockris, 2009\} [22, 23].

A primary engineering objective therefore is the mechanical engineering one of producing wind generators, should always take into account the question of whether the generator can withstand gusts $\{$ B. Roberts et al, 2007\} [24].

Now, a simple theory of the energy obtained from a wind generator starts by recalling that the kinetic energy of a moving mass is given by $1 / 2 \mathrm{mv}^{2}$. The hydrodynamics of the actual transfer of the wind energy due to the rotational action of the blades is the kinetic energy multiplied by the factor 16/27 \{J. Bockris, 2009\} [28].

Thus, the energy of the generator, taken in this ideal picture is $\frac{1}{2} \rho v^{3} \frac{16}{27}$ where $\Delta$ is the density of the air and $v$ the average energy of the wind (over one year).

This is the simplest basic expression possible for a wind generator. However, it is still insufficient and has to be aided by an experimentally added factor, which for most generators is about $1 / 2$ the ideal value \{AWEA, 2009\} [30].

It's important to realize that even this simple equation only applies in the lower regions of wind speeds. The important information that the energy of a wind generator depends on the $3^{\text {rd }}$ power of $\mathrm{v}$, the average wind speed for the year, makes it important to ascertain when the equation begins to break down as the average speed is increased past $20 \mathrm{mph}$.

Thus, does it apply where much higher average wind speeds than that typical of North America (15-20mph) are available \{J. Bockris, 2009\} [25\}? In Patagonia at the tip of South America, there are regions where the average wind speed for nine months of the year, is 40mph.

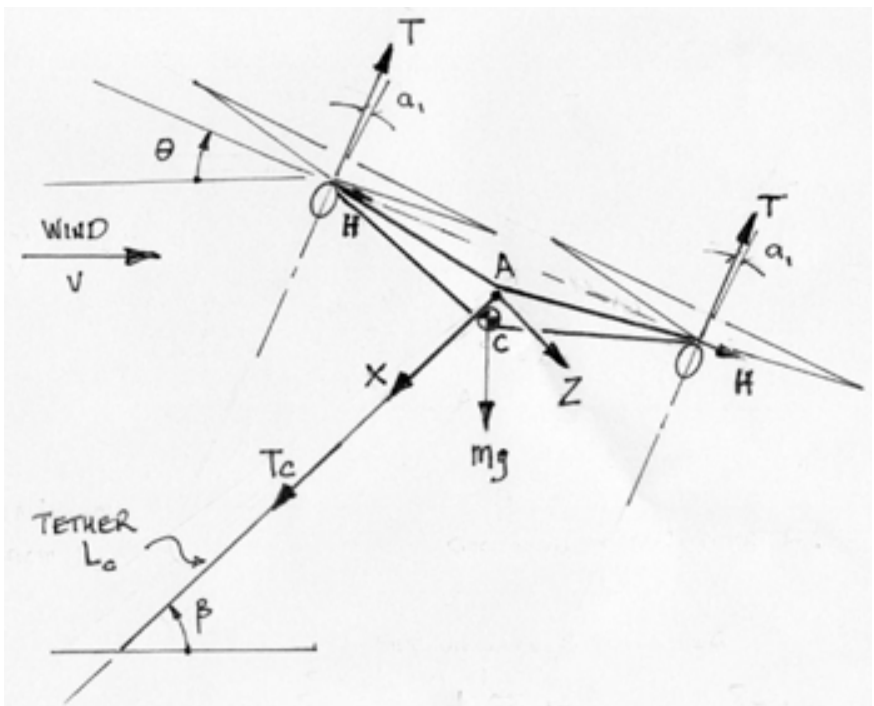

Fig. 12. Diagram of the FEG in flight, showing the craft's nose-up angle which is identical to the control axis, as no cyclic pitch use is planned. The rotor's fore and aft flapping angle, a1, is shown as the angle between the normal to the tip-path plane and the control axis. The total rotor thrust component along the control axis is T, and normal to this axis is the component force $\mathrm{H}$. If $\mathrm{T}$ and $\mathrm{H}$ forces are combined vectorally the total rotor force is almost normal to the tip-path plane \{B. Roberts et al., 2007: [29]. 


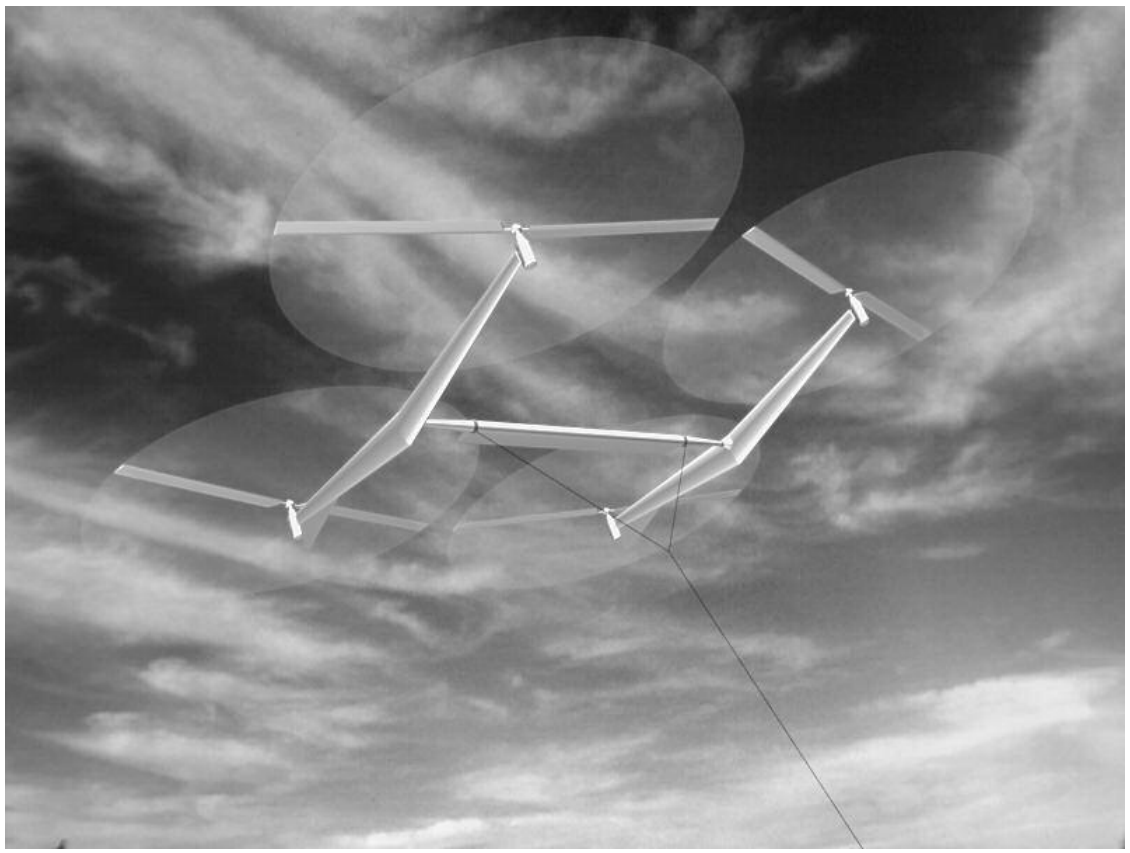

Fig. 13. Rendering of Sky Wind Power Corp's planned $240 \mathrm{~kW}$, four-rotor demonstration craft \{B. Roberts, D. Shepherd, et al, 2007: [29].

The difficulty of putting such great winds to a useful purpose is not only engineering generators that will withstand the gusts from such winds (>120mph?) but also the fact that we do not know the upper limit of the equation derived above. There are qualitative indications, however, that the equation begins to breakdown at about $25 \mathrm{mph}$ and this makes it difficult for in engineering research that might meet the problem of the stability of generators in very high winds \{AWEA, 2009\} [30].

$\mathrm{P}$ is the kinetic energy of the wind per unit volume in time and $\mathrm{c}$ is a hydrodynamic factor for the extraction of energy. However, the equation neglects the effect of rotor-air resistance. The basic empirical equation (Equation 1) is:

$$
\text { Power }=\frac{16}{27} \mathrm{c} \frac{1}{2} \mathrm{pv}^{3}
$$

where $c$ is a parameter, generally taken as $1 / 2$ but falling with an increase in wind velocity. The cube law dependence of power on wind velocity $\mathrm{v}^{3}$ is noteworthy.

The wind equation requires the mean of the cubes of the instantaneous wind velocities over the year. If the mean of the velocities is cubed, results are 2 to 3 times too small \{Bockris, 1975\} [31]."

\subsection{Wind belts}

It is important to locate the rotors in areas ("wind belts") in which the average wind speed is maximal. Due to the rotation of the earth, gravity forces air raised by heat over the equator to drop, colder air on the earth beneath. (Figure 14) [32]. 
Two main systems are shown in Figure 14. The southern pink winds, "trade winds," were vital to sailing ships en route from England to Australia. The ships traveled south of the Cape of Good Hope to reach the West to East wind that blew them eastward to Western Australia and onwards, at about 14 knots. Clearly, the lower the velocity at which winds could be useful, the better. Experience, however, shows that wind speeds below $12 \mathrm{mph}$ are no longer economically attractive. As to the higher speed limit and its practicality, that is not sharply defined. Great advantage is offered by higher winds.

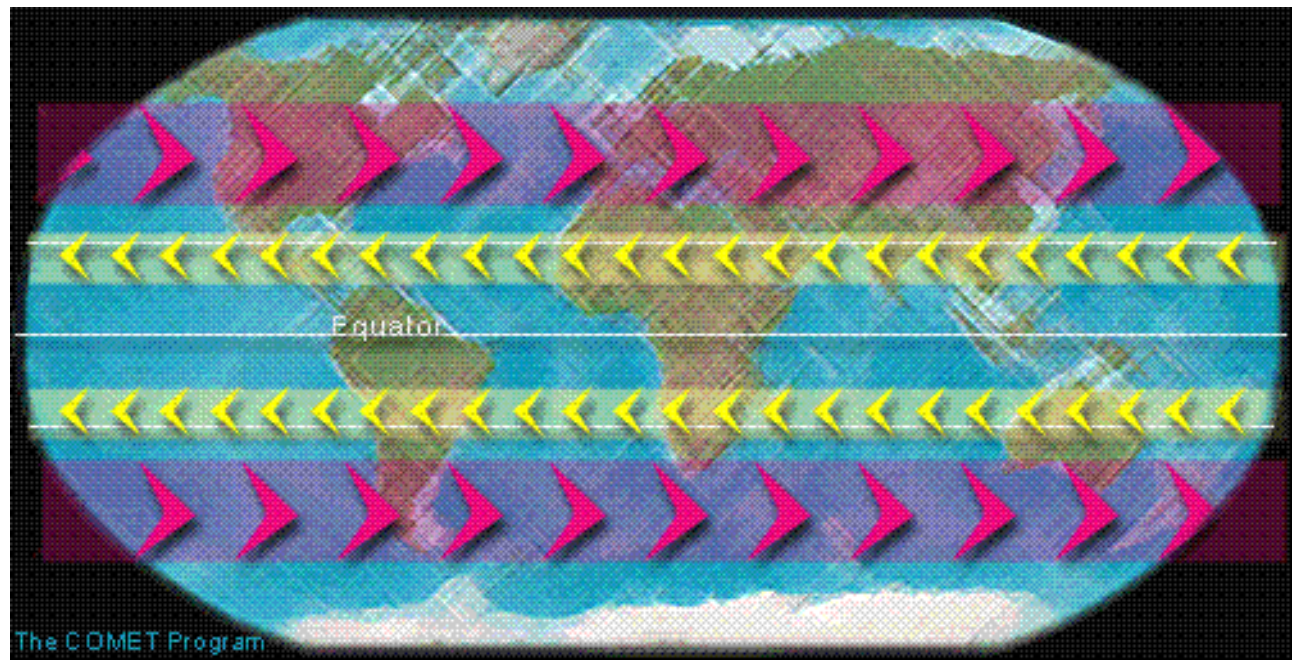

Fig. 14. "World map showing two mid latitude westerly wind belts (shown in pink). The northern belt blows from west to east across North America, the North Atlantic Ocean, Europe, and Asia. The southern belt blows from west to east across the South Pacific Ocean, Chile, Argentina, the South Atlantic Ocean, South Africa, the South Indian Ocean, Southern Australia, and New Zealand. The yellow arrows in the picture also show two tropical easterly wind belts blowing from east to west on either side of the equator. The northern tropical easterly belt blows across the Pacific Ocean, Southeast Asia, India, the North Indian Ocean, the Arabian Peninsula, Saharan Africa, the Atlantic Ocean, the Caribbean Sea, Southern Mexico, and Central America. The southern belt blows from east to west across Northern Australia, the Indian Ocean, Southern Africa, the South Atlantic Ocean, the middle of South America, and the South Pacific Ocean." [32]

\subsection{The distribution of winds}

A picture of the wind belts of the world has been given (Figure 14). However, it is of interest to identify places where the big winds blow. Both the Department of Energy and the Wind Energy Association publish maps of yearly average wind speeds in most parts of the world and particularly those in North America. The following quotations are from documents published by these organizations. [33] The terminology is explained in Table 1.

"Areas that are potentially suitable for wind energy applications (wind power class 3 and above) are dispersed throughout much of the United States. Areas which have useful wind energy resources include: the Great Plains from northwestern Texas and eastern New 


\begin{tabular}{lll}
\hline Class 3 & (Marginal) & $12 \mathrm{mph}$ year average \\
\hline Class 4 & (Satisfactory) & $13 \mathrm{mph}$ year average \\
Class 5 & (Good) & $14 \mathrm{mph}$ year average \\
Class 6 & (Excellent) & 15 and above mph year average \\
Class 7 & (Outstanding) & 16 and above mph year average \\
\hline
\end{tabular}

Table 1. Wind classes and wind speed

"Alaska is Class 7.

Great Plains (North Dakota) area is Class 5

Montana hilltops and uplands are Class 4

Hawaii area has areas of Class 6 but includes Oahu with Class 7 winds."

Mexico northward to Montana, North Dakota, and western Minnesota; the Atlantic coast from North Carolina to Maine; the Pacific coast from Point Conception, California, to Washington; the Texas Gulf coast; the Great Lakes; portions of Alaska, Hawaii, Puerto Rico, the Virgin Islands, and the Pacific Islands; exposed ridge crests and mountain summits throughout the Appalachians and the western United States; and specific wind corridors throughout the mountainous western states."

"Exposed coastal areas in the Northeast from Maine to New Jersey and in the Northwest southward to northern California indicate class 4 or higher wind resource. Class 4 or higher wind resources also occur over much of the Great Lakes and coastal areas where prevailing winds (from the strong southwest to northwest sector) have a long, open-water stretch. The Texas coast and Cape Cod in Massachusetts are the seats of coastal wind resources which extend inland a considerable distance." [33]

"Offshore data from Middleton Island indicate class 7 wind power. Shore data such as Cape Spencer, Cape Decision, Cape Hinchinbrook, and North Dutch Islands reflect class 5 or higher power." "Most of the coastlines associated with these areas are heavily wooded, so wind power estimates are very site-specific."

"Interactions between prevailing trade winds and island topography determine the distribution of wind power. On all major islands, trades accelerate over coastal regions, especially at the corners. The best examples are regions of class 6 or higher wind power on Oahu, Kauai, Molokai, and Hawaii. The rampart-like mountain crests of Oahu enhance prevailing winds to class 6 . On other islands, circular mountain shapes and extreme elevations prevent the type of wind acceleration observed, e.g., on the Oahu ranges."

"On Oahu (Honolulu County), the long Koolau mountain rampart and shorter Waianae Range enhance trades to class 6, although the rugged topography, watershed value, and turbulent air flows over these ranges make practical application more difficult. The northeastern (Kahuku) and southeastern (Koko-head) tips of Oahu have areas of class 7 and broad areas of class 3 or higher. A class 3 and 4 area exists at Kaena Point on the island's northwestern tip, and class 3 areas exist along the southern coast west of Honolulu and southeastern coast north of Makapuu Point." [33]

5 The $\mathrm{v}^{3}$ law makes the difference in wind energy of the outstanding winds as giving more than an twice times termed increase in energy from "outstanding" sources $16 \mathrm{mph}$ ) compared with those term satisfactory $12 \mathrm{mph})$. [18, 18a] 


\subsection{Storage of wind energy [34]}

The peak in the world oil production (apart from tar sands) is likely to come before 2060 . Unfortunately, any new method of obtaining energy, - and wind is the cheapest and the simplest to build, - is going to take more than ten years to build throughout the country, and suggested resources after the peak are the tar sands, coal, or the use of solar energy to grow plants. ( 1 percent efficiency and using more energy to make the alcohol than can be got from it).

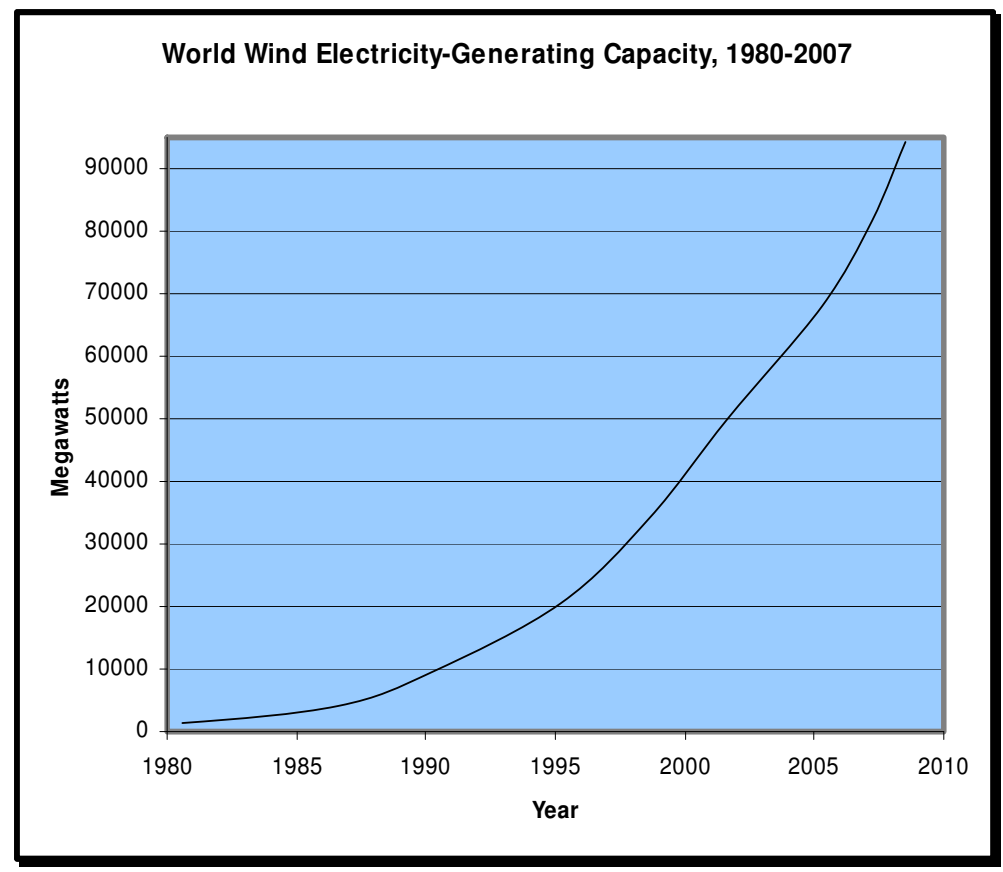

Source: GWEC, Worldwatch.

Fig. 15. From Wind Energy Fact Sheet, American Wind Energy Association, 2004. \{AWEA, 2001\} [35].

There is a new and attractive method for storing electrolytic hydrogen: combine it with atmosphere origined $\mathrm{CO}_{2}$ to form $\mathrm{CH}_{3} \mathrm{OH}$, a liquid. If the $\mathrm{CO}_{2}$ is extracted from the atmosphere, then, when burned, it simply replaces the $\mathrm{CO}_{2}$, - it would be a $\mathrm{CO}_{2}$ neutral process. The combination of $\mathrm{H}_{2}$ and $\mathrm{CO}_{2}$ needs a special catalyst but there is much evidence that it occurs.

The handling, storage, and transportation of methanol will be similar to that of gasoline.

\subsection{The US position in the development of wind technology}

Since the middle 80's the US began to lag behind European Nations (particularly Denmark, Holland and Germany) in the development of wind power (Figure 15) [35]. However, in 2005 , the USA installed more new energy capacity than that of any other country $(2,431$ megawatts). The total cultivated wind energy in this country (2007) is equivalent to only about ten nuclear plants. 
In cases in which yearly average winds above $15 \mathrm{mph}$ are available, the upper limit of wind velocity that can be used in practice depends on engineering resources. Disasters that have befallen wind generators in the past have been brought about by storm-borne gusts of an intensity unallowed for in the design.

Reports of an extension of the capacity of modern wind generators so that they can operate in winds of $50 \mathrm{mph}$ are available $\{R$. Heinberg, 2007\} [36].

\subsection{Effect of height}

Wind increases with height and there has to be a trade off between extra costs of building above the ground and the gain in average wind speed. 30 feet above the ground is used in measuring average yearly speeds. The use of mountain regions looks attractive but wind farms are difficult to build there.

Sometimes natural geographic arrangements give helpful situations such as that in which an approaching wind is increased in velocity by being compressed in a geographically natural funnel.

\subsection{Wind belts at 15,000 feet}

In recent times, a new technology has been born \{Roberts et al, 2007\} [24]. It has been made clear above that it's desirable to stick to wind belts on the ground, but a discovery was made in 2008 \{J. Bockris, 2009\} [25] that similar wind belts exist at heights of 15,000 feet. They found that they are stable and usable for three-fourths of the year. (cf storage devices below).

The Australian American team has been concerned with the collection of wind energy at 15,000 feet. They have used a helicopter modified to contain four rotors. As no forward motion is required of them on these helicopters they do not contain a forward thruster but are tethered to the ground. Tests have been made above the Mojave Desert and also above the Australian outback.

The electricity developed by means of the helicopter rotors is taken down the tether to an area containing water electrolysis plants, which electrolyze the water to produce hydrogen that can be stored at several hundred-atmosphere pressures.

This initiative is, of course, preliminary to any commercialization. The principal doubt is the lastingness of the rotors.

However, the paper published by Roberts et al, (2007)[29] seems to be a fundamental one for the future and if in 2008 it's possible to show that the 15,000 feet winds are usable then it might well be possible within, say, 25 years to look into the jet stream, 40 thousand feet, with speeds of more than $100 \mathrm{mph}$.

It is necessary to look at least thirty years into the future as we build massive low cost supplies to replace the fossil fuels \{K. Deffeyes, 2003; R. Heinberg, 2007; M. Simmons, 2005\} $[37,38,39\}$.

\subsection{Could wind energies be transferred over long distances?}

It has been suggested by Muradov and Veziroglu (2008) [40] that the massive winds available at the tip of South America (Patagonia and southward to and in the Antarctic) could be used as massive energy generation areas.

Of course the first problem to solve is the equation that tells us what the energy received would be under extremely high average winds of $40 \mathrm{mph}$ year average. 
However, there are two possibilities for transferring the large energy amounts that could be made in these artic areas. On the one hand, we can assume that, because of the wind speeds available, the cost of electrical energy is reduced below 1cent per $\mathrm{kWh}$. If this were so, then it would be feasible to think of liquefying hydrogen produced by the electrolysis of seawater. The remote location signifies that care in avoiding transfer to the atmosphere of chlorine is not needed (if it were it can be pumped into the sea).

The circumstances portrayed would justify building modified tankers to take liquefied hydrogen to the northerly parts of the world needing energy.

However, there is another concept which has been documented and which may turn out to be cheaper than the transfer of hydrogen in the liquid form \{K. Deffeyes, 2003\} [37].

\subsection{Potential transfer of energy in a power relay satellite}

Kraft-Ehricke (1973), one of the German rocket team left behind some interesting calculations and diagrams of his concept of transferring large amounts of energy thorough a power relay satellite $\{$ Kraft-Ehricke, 1973\} [41].

In Kraft-Ehricke's concepts the heavy parts of the system are retained on the ground, and the light parts would be put into orbit and be a satellite which is to be hung over the equator. The cost of such a system is largely the cost of putting the satellite into orbit \{KraftEhricke, 1973\} [42].

The satellite should respond to energies on the ground between $30^{\circ}$ north and $30^{\circ}$ south of the equator. Once the beamed energy at microwave frequencies reaches the satellite, it can be directed more or less anywhere in the world and beamed to receiving stations on the ground. This has the possibility of transferring energy virtually anywhere, because, once the

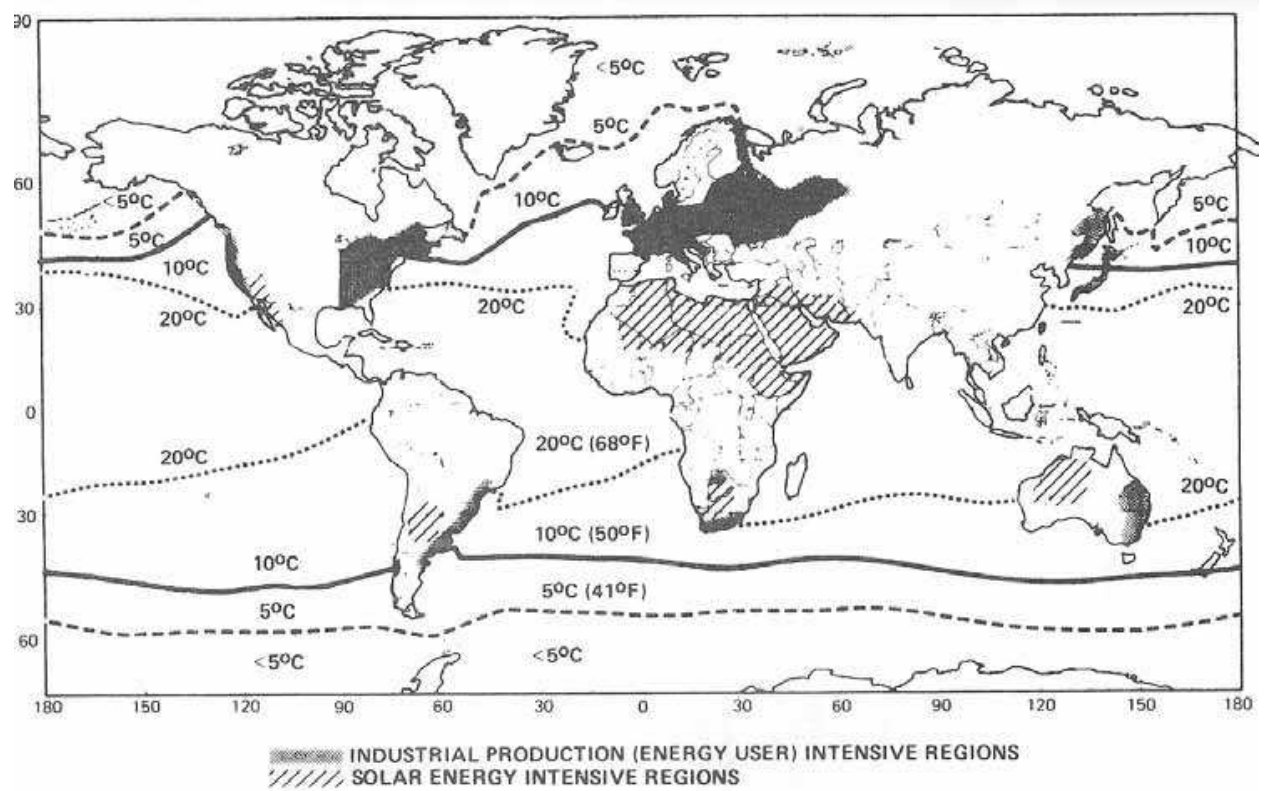

Fig. 16. Figure shows the great distances between areas of high insolation; and those of high concentration of affluent groups with manufacture \{Kraft-Ehricke, 1973\} [41]. 


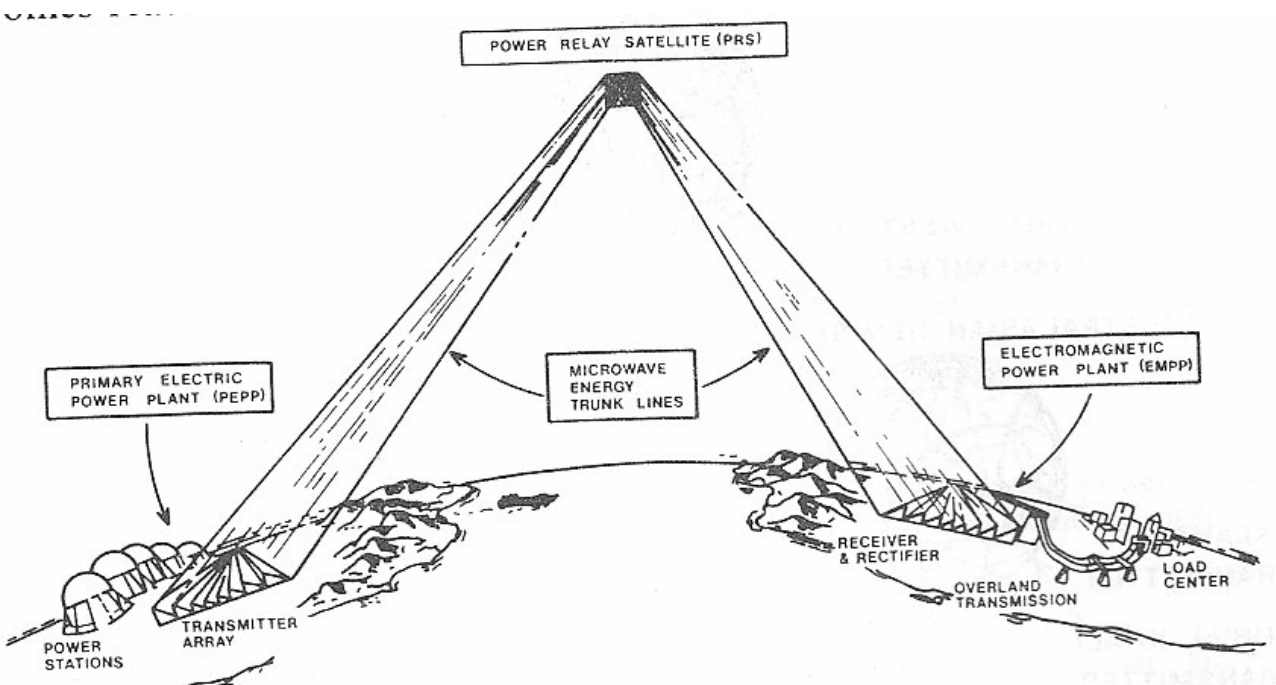

Fig. 17. Power relay satellite concept \{Kraft-Ehricke, 1973\} [44].

\section{POWER RELAY SATELLITE CONCEPT - PERFORMANCE AND COST DATA}

\begin{tabular}{|c|c|c|}
\hline $\begin{array}{l}\text { Power generated } \\
\text { Power delivered } \\
\text { Energy delivered over } 30 \text { years }\end{array}$ & $\begin{array}{l}13,800,000 \mathrm{kwe} \\
9,000,000 \mathrm{kwe} \\
2.1 \text { trition kwhe* }\end{array}$ & $\begin{array}{l}\text { Maximum values. } \\
\text { Beam power can be } \\
\text { less. }\end{array}$ \\
\hline \multicolumn{3}{|l|}{ Transmitter array: } \\
\hline $\begin{array}{l}\text { Construction cost } \\
\text { Maintenance cost ( } 30 \text { years) }\end{array}$ & $\begin{array}{l}\$ 3.1 \text { billion } \\
\$ 12 \text { billion }\end{array}$ & s40/kwe* \\
\hline Overall cost & $\$ 15.1$ billion & 7 mils/kwhe* \\
\hline \multicolumn{3}{|l|}{$\begin{array}{l}\text { Power Relay Satellite } \\
\text { (1 } \mathrm{kW}^{2} ; 300 \text { tons) }\end{array}$} \\
\hline $\begin{array}{l}\text { Construetion fdelivery/erection } \\
\text { Maintentnce cost ( } 30 \text { years) }\end{array}$ & $\begin{array}{l}\$ 0.75 \text { billion } \\
51.5 \text { billion }\end{array}$ & $\$ 84 / \mathrm{kwe}^{*}$ \\
\hline Overall cost & $\$ 2.25$ billion & $1 \mathrm{mil} / \mathrm{kwhe*}$ \\
\hline \multicolumn{3}{|l|}{ Electromagnetic power plant (EMPP) } \\
\hline $\begin{array}{l}\text { Construction cost } \\
\text { Maintenance cost ( } 30 \text { years) }\end{array}$ & $\begin{array}{l}\$ 1.5 \text { billion } \\
50.95 \text { billion }\end{array}$ & $\$ 166 / \mathrm{kwe}^{*}$ \\
\hline Overall cost & $\$ 2.45$ billion & 1.15 mils/kwe \\
\hline \multicolumn{3}{|l|}{ Grand total } \\
\hline $\begin{array}{l}\text { Construction cost } \\
\text { Maintenance cost ( } 30 \text { years) }\end{array}$ & $\begin{array}{l}55.3 \text { billion } \\
\text { \$1 } 4.45 \text { billion }\end{array}$ & $\$ 590 / \mathrm{kwe*}$ \\
\hline Overall energy transmission cost & $\$ 20$ billion & $9.3 \mathrm{mils} / \mathrm{kwhe} *$ + \\
\hline
\end{tabular}

- Power delivered.

I According to a newer analysis, taking into account the lessened maintenance cost caused by the development of platinum-coated amplitrons - this cost goes down to about 5.2 mils $/ \mathrm{kWH}^{2}$ (but this does not include the capital cost. which puts the
figure up to $10 \mathrm{mils} / \mathrm{kWH} \mathrm{H}^{-1}$ ),

Table 2. \{Kraft-Ehricke, 1973\} [44]. 
TRANSMITTER RANGES AT 4 DEGREES MERIDIONAL

TRANSMISSION ANGLE AND LONGITUDINAL

TRANSMITTER-RECEIVER RANGE OF 54 TO 60 DEGREES

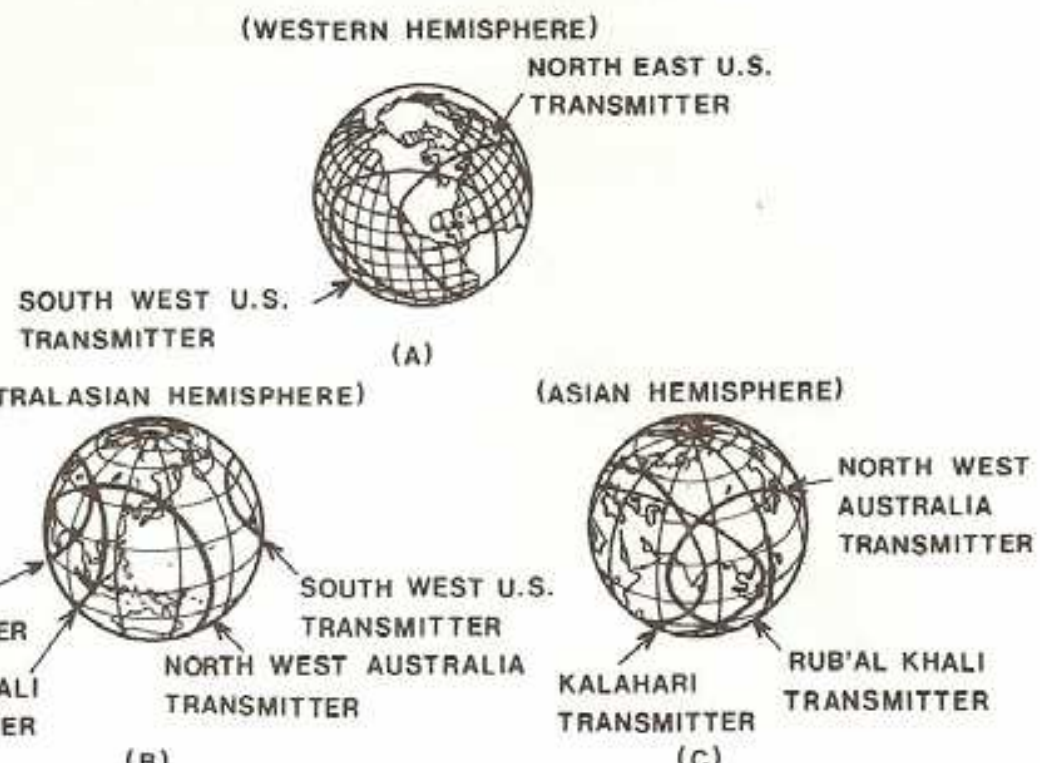

(B)

(c)

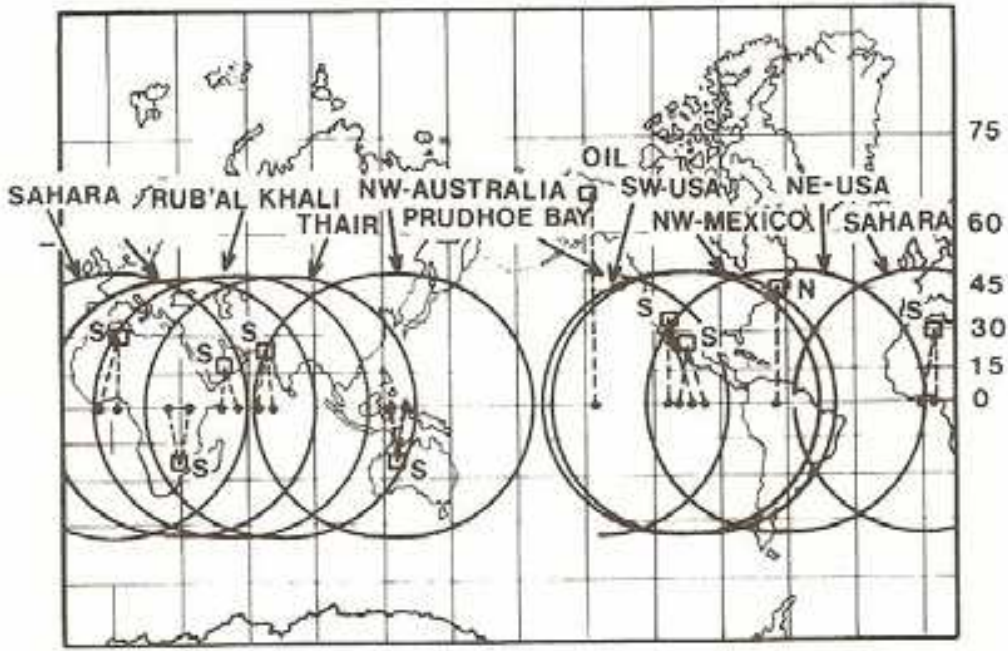

(D)

Fig. 18. Range of a number of Primary Energy Power Plant Systems \{Kraft-Ehricke, 1973\} [44]. 


\section{CHARACTERISTICS OF MICROWAVE-PRS ENERGY SYSTEM}

Microwave Energy (point-to-point transmission via power relay satellite).

NOTE:

$\mathrm{MW}=$ microwave

PRS $=$ power relay satellite

$k w b=$ kilowatt beam power; as used in (C), kwb refers to the beam power at transmitter aperture

kwe* $=$ dc electric kilowatt as delivered at the bus bar of the receiver power plant.

A General

Avoids questions of engineering overseas pipeline; building tanket feet. Because of high cost of the transmitter, is economically important to use energy sources lasting at least 30 years, i.e. largely for transmission solar energy from high insolation areas or exporting fusion energy.

B Processing

Conversion to MW energy at high efficiency $(\geq 90 \%)$ in microwave power generators at the expected state of the art at mid-1980s. Transmission efficiency over several thousand miles $50-60 \%$.

C Laading

As phase-controlled MW beam in transmitter antenna. Antenna size large, but not prohibitive $\left(\geqq 138,000 \mathrm{kwe} / \mathrm{km}^{2}\right)$. Relatively high construction cost, due to stringent engineering requirements $\left(\sim \$ 3 / \mathrm{ft}^{2} ; \sim \$ 31 \mathrm{M} / \mathrm{km}^{2} ; \sim \$ 295 / \mathrm{kwb} ; \sim \$ 340 / \mathrm{kwe}^{*}\right)$.

1) Shipping

Power Relay Satellite (PRS) in geosynchronous orbit needed for beam redirection. Stringent PRS engineering requirements. But moderate construction cost $(\sim \$ 84 /$ kwe* $)$ due to small size $\left(\sim 1 \mathrm{~km}^{2}\right)$ and to shuttle which keeps maintenance low. Environment effects of beam on atmosphere are small.

E Unloading

Receiver-rectifier system (rectenna) of $85 \%$ conversion efficiency to de current. Therefore, littie thermal load. Environmental burden? Receiver size is larger, but not prohibitive $\left(\gtrsim 90,000 \mathrm{kwe} / / \mathrm{km}^{2}\right)$. Receiver power plant coristruction cost is small $\left(\sim \$ 166 / \mathrm{kwe}^{*}\right)$. Operating costs low. Operation is simple, making system suitable for export and use in developing countries.

F Storage

Has no storage capacity, would need to convert to hydrogen, anyway.

G Conversion to electricity

In rectenna, conversion to ac after electric transmission close to load centre.

H Transmission to user

Receiver power plant can be located near load centres, due to its low socioenvironmental burden quotient. De-power transmission yields superior efficiency to ac-power transmission,

"Table originatés in ref. 5 , but modified.

Table 3. Systems Kraft-Ehricke, 1973\} [44]. 
energy has left the ground in microwave beam form, its transfer is more or less equal in cost if it's transferred 1000 miles or 5000 miles, it depends upon the orientation given in the satellite \{Kraft-Ehricke, 1973\} [43].

Thus, solar energy from the ground could be converted to electricity and eventually beamed at microwave frequencies to strike the satellite, which then orients it toward any desired location. Australia, North Africa, Saudi Arabia, would be places from which solar energy in massive amounts could be beamed.

Transmission of energy by microwave beams must have a load reception center at the end, where a country needing energy receives the beam. For example, 59\% of the entire Australian continent is open for solar energy exploitation\{Kraft-Ehricke, 1973\} [44].

In Ehricke's plan, (1973) \{45], transmitting and receiving antennae would consist of very many individual elements \{J. Bockris, 1975\} [46]. He suggests a helix antenna 1.4" in diameter, 14" in length.

Receiving areas depend on many things, such as Osaka, Japan, or London, England, are places where large amounts of energy are needed and Australia is a place from which very large amounts of solar energy can be created \{Kraft-Ehricke, 1973\} [43].

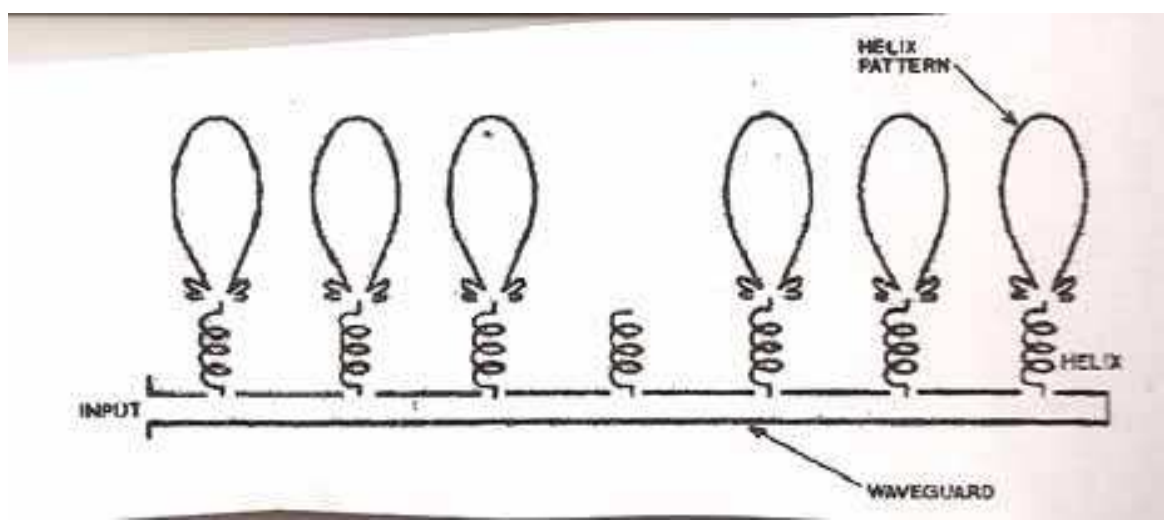

Fig. 19. Linear array of waveguide-fed helix elements \{J. Bockris, 1975\} [46].

\subsection{Wind and Sun}

There are many considerations that could influence a community that would have to decide if it wanted wind and sun as the origins of its energy supply \{R. Heinberg, 2007\} [38].

Of course there is a need for a detailed study of the average available solar or wind before a decision. Solar intensity is optimal roughly 3000 miles on each side of the equator. Wind tends to be the superior source outside this area but one other aspect of the matter is that the solar source is available for only six to eight hours per day. (Except for OTEC.)

Wind energies in general are available for 24 hours per day but whereas the solar energy can be reliable knowing the history of the location, wind energy is more subject to sporadicity. At the present time, around 2010, North Africa is the place where the commercial development of the solar source is making progress \{M. Simmons, 2005\} [39] particularly important as it is with an exhausting oil supply \{A. Cristian, 2008\} [47].

On the other hand, Europe is the place where there is a major development of wind energy (particularly in Denmark and North Germany) 


\subsection{Cost of wind energy}

Discussions of wind energy in the 2008 literature are often aimed at small-scale wind farms or even individual users. The problem with them is that they mix up the (large) amortization costs of construction with the (small) cost of operating and servicing the equipment. The amortization costs are spread out over the expected life of the plant (twenty to thirty years) so that the low costs of wind energy, free of repayment for the costs of construction, are seldom brought out [48, 49]. (2008 forecasts of wind energy by 2010 are quoted at 3.5 cents per $\mathrm{kWh}$ - well below the corresponding prices of commercial electricity in the USA at that time) [50].

\subsection{Range of practical wind energies}

With wind turbine technology, commercially available in the U.S. in 2010, the acceptable wind velocities ranges are from $12-15 \mathrm{mph}$, this is the practical range of wind energy for use under 2008 conditions and acceptable to the US Department of Energy in that year $\{\mathrm{N}$. Muradov and N. Veziroglu, 2005\} [51].

This small range of practical wind speeds explains why the costs of wind energy are often stated without defining the wind speed. In 2006, the range of total costs (construction and operating) quoted by DOE, are 4-6 cents per kWh, but the National American Wind Energy predicts 3 and even 2 cents per kWh within a decade from 2007. No other source, except paid off hydro could compare with these costs, half the costs of polluting fossil fuel based electricity.

Among published costs of recent times are those of some wind farms of $0.51 \mathrm{MW}$. The dependence of cost on wind speed, experimentally established is as follow:

$$
\begin{aligned}
& 16 \mathrm{mph}=4.8 \text { cents } \mathrm{kwh}^{-1} \\
& 18 \mathrm{mph}=3.6 \text { cents } \mathrm{kwh}^{-1} \\
& 21 \mathrm{mph}=2.6 \text { cents } \mathrm{kwh}^{-1}
\end{aligned}
$$

and thus show a sizable effect of wind velocity in present practice. Reports from nongovernmental sources in the USA extend acceptable wind speeds to higher values and lower costs $\{$ DOE, 2010\} [52].

One tends to look back to Churchill's description of the defeat of the Nazi Air Force by the Royal Air Force, in the Battle of Britain in World War II (1941). "Never has so much been owed by so many to so few". Applied to the present situation of development of clean energy in the USA, one might write "Never has so much been left unused by so few, when needed by so many" \{DOE, 2010\} [52].

\subsection{Summary of wind energy}

The main advantage of wind energy is low cost. The only cost lower than that obtainable from winds, is that of paid off hydroelectric plants, massively developed in Canada.

One of the advantages of wind energy is that the developer can receive a profit from his purchase within days of the machinery being delivered to him whereas with some other developments of renewable energies, extensive building may have to be done.

On the other hand, wind is challenged by the Enhanced Geothermal source. It is too early, only two plants in hot rock geothermal have been built, - to make a well-informed comparison as to cost. Present production of futuristic schemes for wind might be thought to out range those for the hot rock costs. 


\section{The Earth's temperature}

The amount of energy, e.g. from the sun, varies over the long term, and for many centuries there has been a slow but small decrease. Then, there is the question of heat from the earth, which contains heat-emitting radionuclides.

There may be other causes for the variation of the earth's temperature. The reason why these changes are little discussed in dealing with Global Warming is that they are much slower in respect to rate of change than those we are seeing. (This warming correlates with the increase in the use of carbon-containing fuels).

\subsection{Attitude of the oil companies to global warming}

Although the general talk among citizens has been for many years that oil is exhausting, the oil companies have often denied this. On the other hand, books are now being written about Saudi Arabia in particular and what we take from them is that the main well (huge in extent) in that country is no longer a sure supply for the future. There have been many values put forward for the Hubbert peak (Hubbert made the first scientific estimate of the amount of remaining oil) \{K. Deffeyes, 2003\} [53].

It is a matter of good business that oil companies will continue to sell oil (and damage the atmosphere) whilst it is still a desired product, i.e., until either there is a cheaper fuel (from wind) or our government has the votes to introduce a carbon tax to make alternative fuels relatively cheaper.

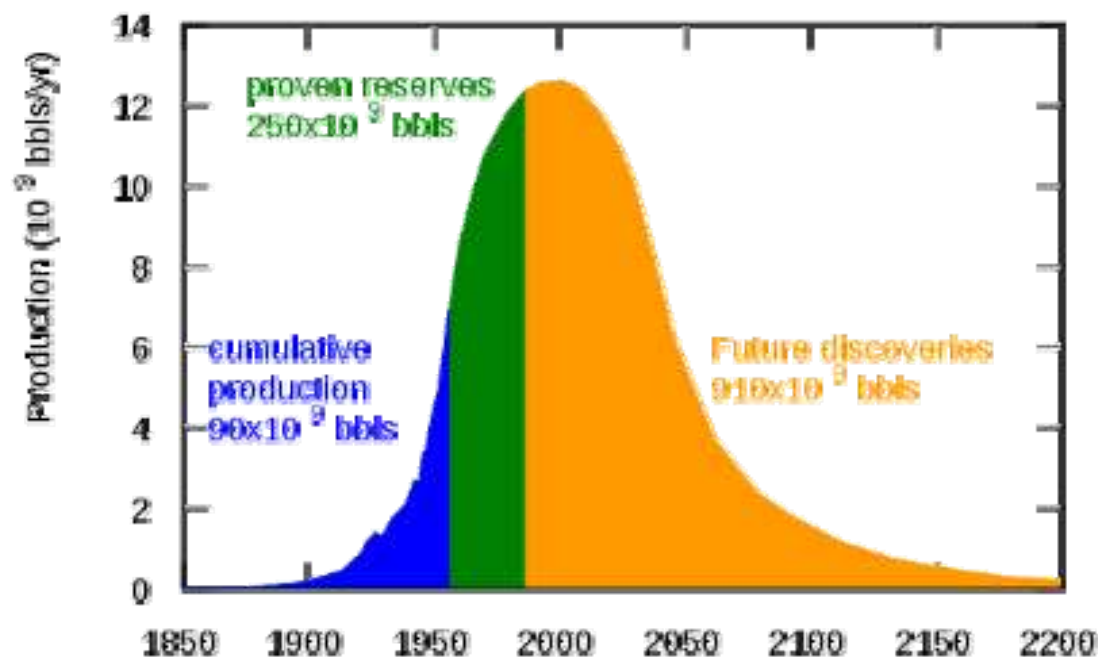

Year

Fig. 20. New presentation of data in figure 20 of

http:/ / www.hubbertpeak.com/hubbert/1956/1956.pdf. Meant as replacement for non-free en::Image:Hubbert-fig-20.png 2007-03-04 (original upload date) Transferred from en.wikipedia; transferred to Commons by User:Pline using CommonsHelper Original uploader was Hankwang at en.wikipedia CC-BY-2.5; Released under the GNU Free Documentation License 
Some analogy may be drawn between the damage scientifically proven to those smoking tobacco and the present population, damaged in health by inhaling polluted air from certain $\mathrm{CO}_{2}$-producing fuels.

During the last ten years we have identified three successive peaks. The one Hubbert put forward came at the year 2000, but after that there have been successive predictions by seriously minded experts on oil supplies. Every time a later one has followed the prediction of a peak, and the cause of these changes is that from time to time, even now, discoveries of new oil are being made.

Now, these discoveries are not always of oil, but rather in getting access to it. There are still sources of oil within the United States that have not been tapped. The reason why they are not usually counted is that they are often covered with thick layers of rock that, in the past, have been thought of as impenetrable, hence useless.

On the other hand, progress is being made in drilling which can indeed penetrate thick rock layers. For example, quite recently, a major find became operable near the Montana, North Dakota, and Saskatchewan border \{A. Cristian, 2008\} [54].

What we hear is that this deposit should provide us with more oil than we expect to get from Saudi Arabia. Consequently, the greatest burden on the budget is our armed forces may be resolved. Looking, then, to a fifty year future, our greatest danger is not exhaustion of oil, - but the temperatures of the future atmosphere.

\subsection{Solutions to global warming}

\section{General}

Discussions of Global Warming are often obscured by the fact that people who make proposals are often interested in short-term gains whereas anything we do to eliminate the negative effects of the warming climate would have to last at least thirty years in which time we expect still to be using some oil.

A good example of this is the activity of Virgin Airlines companies $\{2008\}[55,56,57]$ that offer a multi million-dollar prize to anyone who could solve the problem of Global Warming $\{$ K. Deffeyes, 2003; R. Heinberg, 2007; M. Simmons, 2005\} [53, 58, 59]. However, it became clear that the winner would be he who found how to eliminate $\mathrm{CO}_{2}$ whilst still burning the fossil fuels.

There are numerous ideas about what is called "sequestering"

The $\mathrm{CO}_{2}$ is to be removed from plants producing electricity by burning coal and of course from the automobile. The difficulty off this approach involves catching the $\mathrm{CO}_{2}$ in some kind of cheap compound, for example, lime, $\mathrm{CaO} . \mathrm{CO}_{2}$ easily combines with lime and therefore devices, which will be attached to cars producing large amounts of $\mathrm{CO}_{2}$, might be followed with machinery to remove calcium carbonate. (Bury it?)

However, the problem here is that the amounts of the carbonate produced per day would be huge, and the problem then would become where to put it and the cost of getting it there.

Another kind of solution to sequestration is to bury the $\mathrm{CO}_{2}$ in the sea but at deep levels, more than 3,000 feet when $\mathrm{CO}_{2}$ becomes a hydrate and sinks.

One other partial solution to Global Warming would be to adopt a reaction first studied by Muradov (2005) [60]. The latter found that natural gas, passed through a zone at about 950。 C, containing low cost catalysts, methane becomes carbon and hydrogen. The carbon can be dealt with, e.g. by burial. Pure hydrogen is liberated. 
The problem becomes the limitation to the available natural gas and the problem of where to put the carbon and the cost of transporting it there. This is hardly a permanent solution and would require moving to a Hydrogen Economy.

\subsection{Solar energy as a replacement for that from fossil fuels}

Solar energy is undoubtedly the public's view of a future without fossil fuels or nuclear energy. Its antipathy towards the latter arises because of Chernobyl and other nuclear accidents that have killed thousands of people. U.S. workers now claim to pack the nuclear material in such a way that a meltdown is difficult to imagine.

The sun's light can be turned into electricity in a number of ways.

The easiest one to describe, and also at present the cheapest, is called the "solar thermal" method [61].

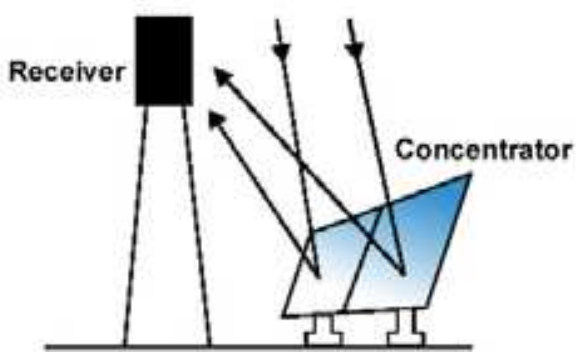

(a)

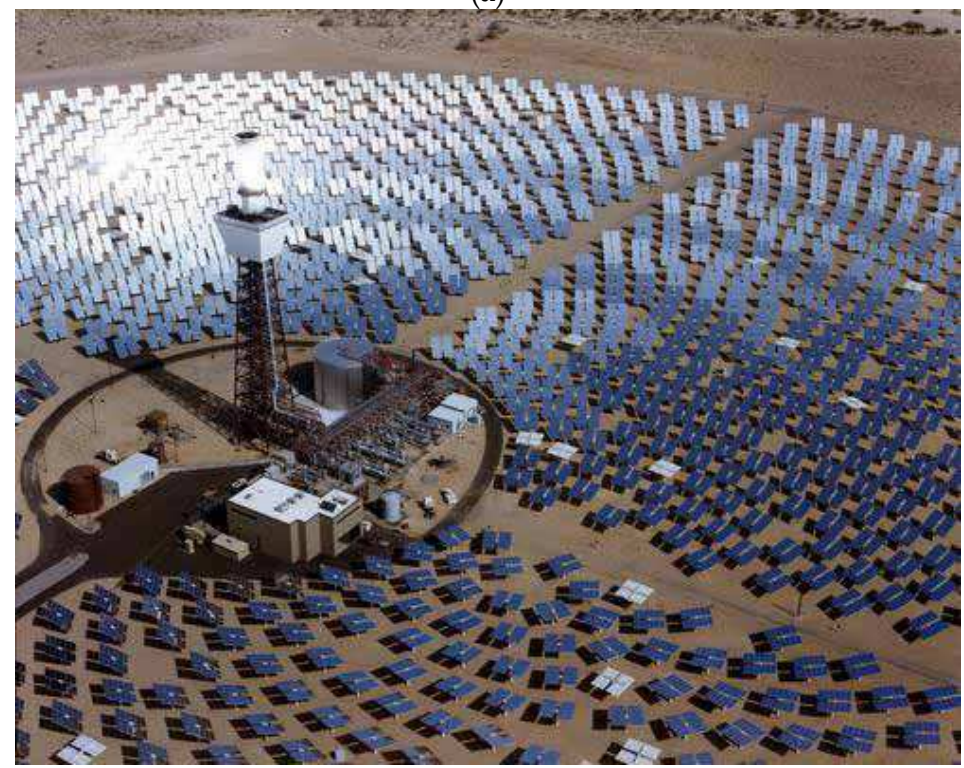

(b)

Fig. 21. (a) Schematic of a power tower. Image adapted from Energy Efficiency Renewable Energy Network \{J. Tidwell, 2005\} [61];

(b): Solar Two, power tower. Image courtesy of NREL's Photographic Information Exchange [62]. 


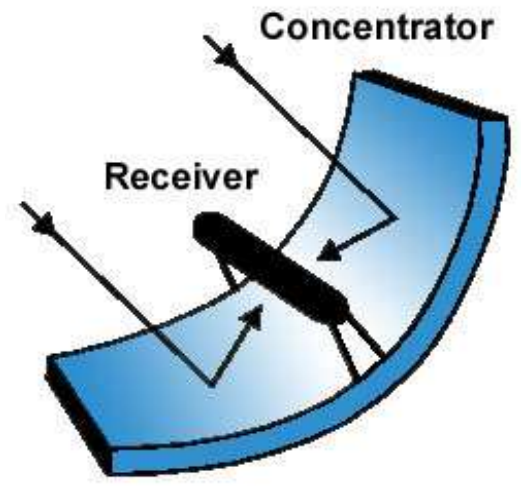

(a)

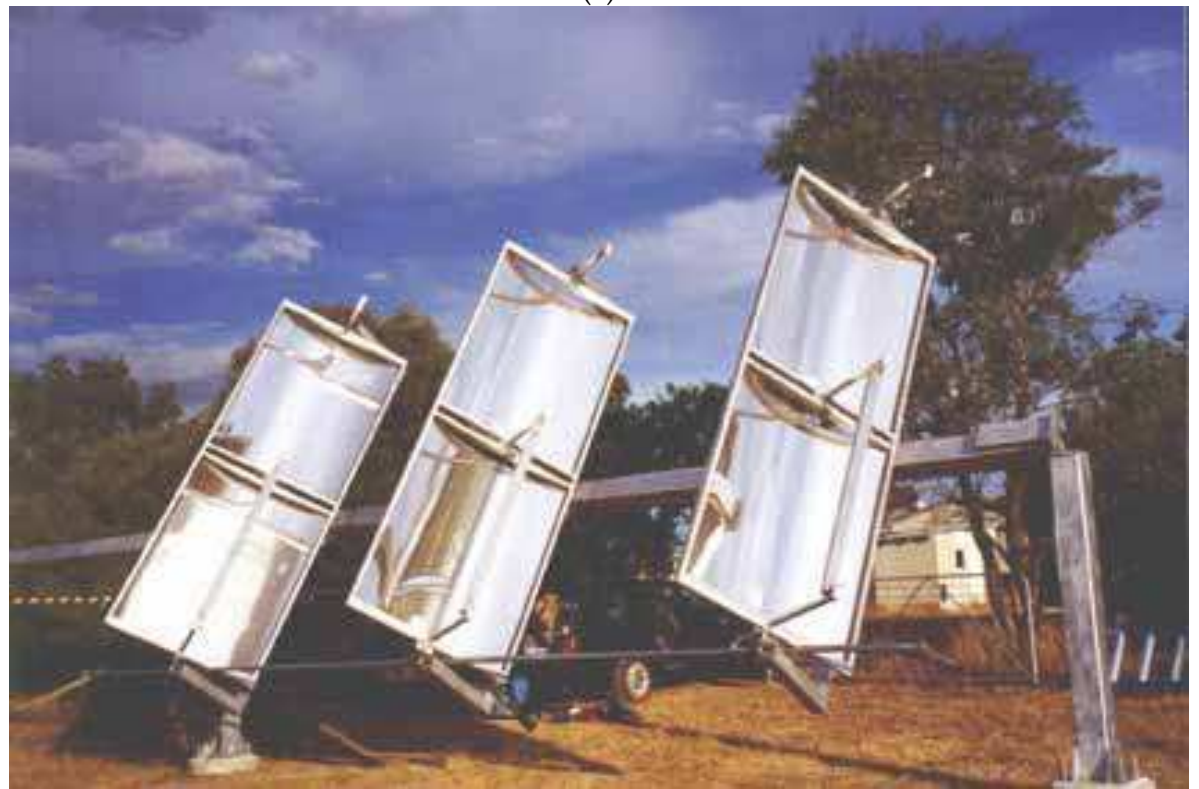

(b)

Fig. 22. (a) Schematic of a parabolic trough concentrator. Image adapted from Energy Efficiency Renewable Energy Network \{Council of Australian Governments, 2006\} [63].

(b) Trough concentrator system at the Australian National University, which is designed to incorporate photovoltaic power generation or water heating and steam production. (Image courtesy of the Centre for Sustainable Energy systems, Australian National University, \{Wyld Group, 2009\} [64].

It is remarkably simple and consists of many mirrors that are oriented towards the sun so that they can all focus the reflected beams on something that exists at the top of a tower. Usually this latter is a boiler containing water, which boils as a result of the sun's light, the steam being led to a conventional steam turbine. The electricity producing machinery is held underneath the tower. 
At present, 2010, about $1 / 2$ of the practical solar energy in use (largely in North Africa) uses this solar thermal method.

\subsection{Photovoltaics}

This is the second most well known method for converting solar light to electricity; the heart of the method is two slabs of (often) silicon. One is called the p type and the other the $n$ type.

The electron concentrations in the $n$ type are high and the $\mathrm{p}$ type low. What fills the $\mathrm{p}$ type is called holes, a puzzling name but what it means is sites where there are no electrons.

When a beam of light falls upon these couples as they are called, a potential difference is created between the two sides, the $\mathrm{n}$ and the $\mathrm{p}$. It is a low potential, about 0.6 volts at open circuit.

A great number of solar cells have to be connected in series to give power to a hypothetical grid that has been tested out by some trials in California but has not yet been commercialized.

The efficiency of the collection of light is only $16 \%$ for relatively big cells (the biggest cell is only about eight inches in diameter) but efficiencies can be obtained with small cells created under careful and clean laboratory conditions, together with some kind of roughening technique so that the incoming light is absorbed and reflected light absorbed again. Efficiencies may be increased.

There are big ideas for developing photovoltaics, thus there has been published a plan where the company claimed to be able to paint a photovoltaic onto a big surface, for example a sheet of aluminum foil. A relatively gigantic sheet of this foil, duly covered with a photovoltaic was supposed to hang on the side of buildings in towns \{Popular Science, 2007\} [65].

The efficiencies of collection from such devices using photovoltaic materials which avoid silicon was found to raise the efficiency of collection, although the report which described this did not publish an efficiency figure for the conversion of light to electricity.

The commercial income from such a production would be so great that the realization of many of the things which had been promised is almost certain to be realized in the next few years. In fact, the idea of "painting" a photovoltaic onto the aluminum foil was suggested in the 1980s.

The commercializations of Nano-Solar's new techniques have been slow and some German academics have denounced Nano-Solar propositions as impractical.

\subsection{OTEC (Ocean Thermal Energy Conversion)}

The basic idea of this method, which although not yet built on a large scale, is often referred to as the French physicist Arsene d'Arsonoval suggested the most impressive of the solar energy converters at the end of the $19^{\text {th }}$ century.

It depends on the temperature of the surface of the tropical sea that is usually more than 2 $5^{\circ} \mathrm{C}$ and the temperature at the bottom of the ocean that is generally about $4-5^{\circ} \mathrm{C}$. It follows that we have around $20^{\circ} \mathrm{C}$ difference to work with and the physicist's idea was that this was enough to run a heat engine with a low boiling point working fluids (liquid ammonia). A long tube lowered from a floating platform on the sea surface and a pump is used to draw up the very cold water from the sea bottom $\{\mathrm{A}$. Aponte\} [66]. On the surface of the platform, one would have hot $\left(25-30^{\circ}\right)$ and cold $\left(4-5^{\circ}\right)$ water. A heat engine can thus be run. 
The efficiency of energy conversion is very low, about 4 percent, but this is not important for we have an almost infinite amount of heat from the surface of the sea, and cold from the sea bottom. (Figure 23.)

There is another version of OTEC and this does not use the working fluid ammonia, but simply evaporates and condenses water by means of pressure changes. Water is made to boil by lowering the pressure.

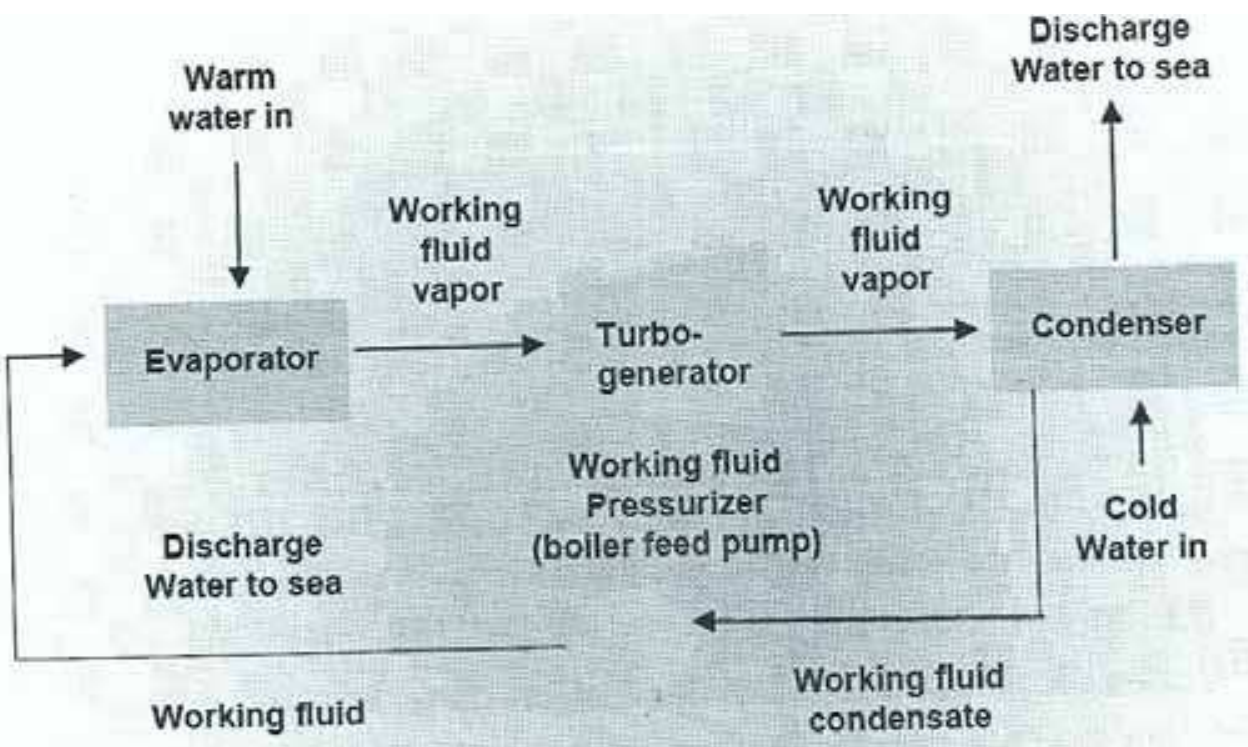

Fig. 23. Schematic of Closed-cycle OTEC system. Closed cycle OTEC Schematic-Ocean Thermal Energy Conversion: Possible application in Certain Pacific Island Nations, a\{Alicia Altagracia Aponte\} [66].

This second version has the advantage of producing fresh water from seawater.

The potential production of fresh water from seawater on a large scale is financially important. The OTEC machinery needs help when it comes to financing because it is about twice more than other methods (per kw).

However, OTEC would work 24 hours per day because the sea surface is hardly affected by night.

\subsection{A new approach to the conversion of light to electricity}

It is admitted by all workers in the field the chances that photovoltaics could be really much reduced in cost and increased in efficiency were not very great. It is true that if one wants to go to very tiny cells, then the efficiency is greatly increased past 16 percent right up to more than 32 percent, but the cells were too small to be of commercial value.

In 2006 a new star appeared on the horizon. The name of the company is Nano-Solar, and from its announcement and from the records we have of people who have visited the company, and seen what they do, there's hope that they are making a revolution in photovoltaics seems quite right. 
What I am able to tell you here is only from material I have from the year 2007, which is when they admitted a visitor from outside to their headquarters, which was then in the Silicon Valley, and he told the following:

One enormous change which Nano-Solar seems to have been able to engineer has come from a suggestion that was made long ago by John Appleby. John, - and indeed perhaps others, - have always thought about for a long time about the possibility that they could "paint" the photovoltaic onto some other fabric or metal sheet such as aluminum foil, and stretch this foil out having great dimensions so that all talk of centimeters and small numbers would be abandoned and great areas were to be covered with photovoltaic which would then be able to be exposed, e.g., to the sides of houses or factories in towns.

Nano-Solar claimed that they had done this essentially but they also brought to light a new photovoltaic concept by mixing four different photovoltaics together as part of that material which they paint on to the aluminum foil. Obviously this achievement makes a revolutionary difference to the possibilities of using photovoltaics, and instead of having tiny cells, which many thousands had to be used to speak of powering a town, there's now every possibility that photovoltaics could be used in the future developments for such things as powering towns and cities, - so long of course refinement was growing at that time or for that application.

Now, the development of this company has been delayed and this comes out of two causes. First of all, the company in the fact that it has very large private backing. So there is no problem in respect to monetary support.

Secondly, however, a number of academics, particularly in Germany, have made criticisms of Nano-Solar saying that their technology can't work and it will be unsuccessful when developed to full scale.

One of the problems of reporting, as I am trying to do, progress with Nano-Solar is that they are loath to answer correspondence. They say that they will only answer correspondence, "to their advantage," which I suppose means that when they think that the correspondence will lead to financial gain and advantage for the company, they answer, otherwise they ignore.

Of course, for a person who wants to report the latest progress about the company is very difficult because direct questions such as what is the efficiency of the new photovoltaic are not directly answered, or the price of a kilowatt-hour of electricity in a certain location are not answered.

Therefore, at this time, I can tell you only that the company has already spread out and have headquarters now in Switzerland and having offices in Germany and the United States.

My own perception of Nano-Solar is that it is far the most idea-based, fruitful, and the most ideal development in photovoltaics, and my opinion is that the progress that will be made in the next ten years, at a practical level, from Nano-Solar is very probable and very great.

\section{Geothermal: developed to give large amounts of clean energy?}

There is an aspect of the earth's heat energy and this might make an important contribution to the clean heat energy we need. As "hot rock geothermal" the idea has been known since the early sixties, but no large-scale plant has yet been built, although recently small exploratory plants have been built in France and Germany and a large plant, worth several nuclear reactor is being built in Australia.

Basically, one focuses attention on flat parts of the earth and builds therein bores into the earth to depths of a few kilometers until one meets heat enough to boil water. 


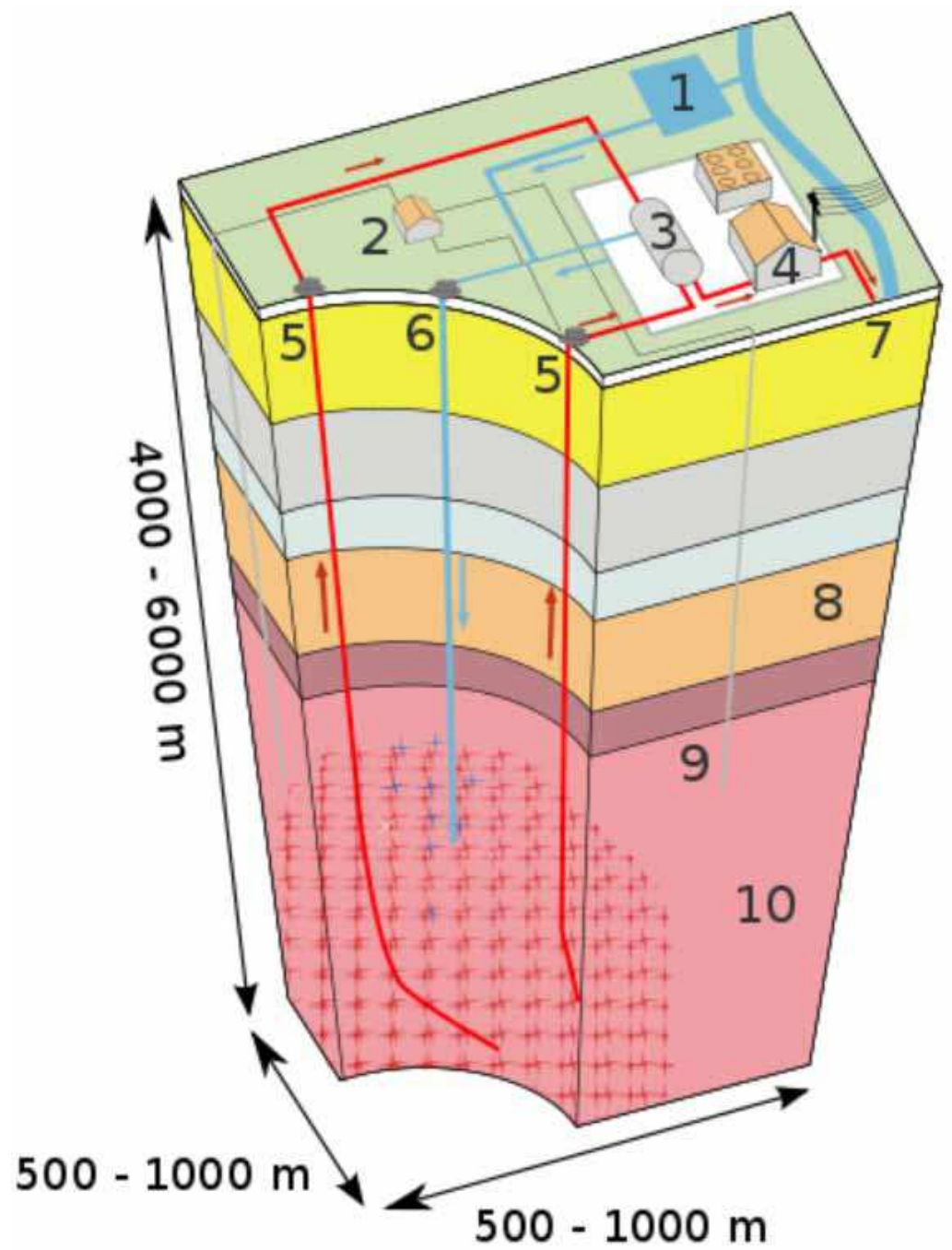

Fig. 24. Diagram of EGS with numeric labels. 1:Reservoir 2:Pump house 3:Heat exchanger 4:Turbine hall 5:Production well 6:Injection well 7:Hot water to district heating 8:Porous rock 9:Well 10:Solid bedrock. 2009-10-24 13:49 (UTC) Geothermie_Prinzip01.jpg Geothermie_Prinzip.svg: Geothermie_Prinzip01.jpg: "Siemens Pressebild" http://www.siemens.com derivative work: FischX (talk) Geothermie_Prinzip01.jpg: "Siemens Pressebild" http:// www.siemens.com derivative work: Ytrottier This file is licensed under the Creative Commons Attribution-Share Alike 3.0 Unported license. You are free: to share - to copy, distribute and transmit the work; to remix - to adapt the work Under the following conditions: attribution - You must attribute the work in the manner specified by the author or licensor (but not in any way that suggests that they endorse you or your use of the work). share alike - If you alter, transform, or build upon this work, you may distribute the resulting work only under the same or similar license to this one [67]. 
Then, one injects cold water down this bore, one can expect to receive electricity-generating steam.

Does the bore cool down until eventually one has to rest it? Some designs suggest this, and then work with a twin bore that takes over for a few years. Eventually, this second bore will cool down and heat from the first bore (duly hot again) is used for a cycle.

A recent report has been made on Enhanced Geothermal at MIT.

The advanced Swiss plans only have one bore, and circulate a pipe leading from it inside the hot zone. This brings the entering water up to the requisite steam in this pipe alone, steam is led back and up to the surface and on to the electricity producing machinery, later as "cold" water, it goes back into a bore.

Literature on these geothermal methods describes the fact that when the cold water strikes the bottom of the bore, it may split the rock, expose a further hot region.

\begin{tabular}{|c|c|c|c|c|c|c|c|}
\hline \multicolumn{8}{|c|}{ Current EGS projects } \\
\hline Project & Type & Country & Size (MW) & \begin{tabular}{|l|} 
Plant \\
Type
\end{tabular} & \begin{tabular}{|c|} 
Depth \\
$(\mathbf{k m})$
\end{tabular} & Developer & Status \\
\hline Soultz & $\mathrm{R} \& \mathrm{D}$ & $\begin{array}{c}\text { France } \\
(\mathrm{EU})\end{array}$ & 1.5 & Binary & 4.2 & ENGINE & Operational \\
\hline $\begin{array}{l}\text { Desert } \\
\text { Peak }\end{array}$ & $\mathrm{R} \& \mathrm{D}$ & $\begin{array}{l}\text { United } \\
\text { States }\end{array}$ & $11-50$ & Binary & & $\begin{array}{l}\text { DOE, Ormat, } \\
\text { GeothermEx }\end{array}$ & Development \\
\hline Landau & Commercial & $\begin{array}{c}\text { Germany } \\
(\mathrm{EU})\end{array}$ & 3 & Binary & 3.3 & $?$ & Operational \\
\hline $\begin{array}{l}\text { Paralana } \\
\text { (Phase 1) }\end{array}$ & Commercial & Australia & $7-30$ & Binary & 4.1 & $\underline{\text { Petratherm }}$ & Drilling \\
\hline $\begin{array}{c}\text { Cooper } \\
\text { Basin }\end{array}$ & Commercial & Australia & $250-500$ & Kalina & 4.3 & Geodynamics & Drilling \\
\hline $\begin{array}{c}\text { The } \\
\text { Geysers }\end{array}$ & Demonstration & $\begin{array}{l}\text { United } \\
\text { States }\end{array}$ & (Unknown) & Flash & $\begin{array}{c}3.5- \\
3.8\end{array}$ & 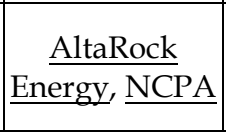 & $\begin{array}{c}\text { Fundraising } \\
\text { (Mar 2010) } \\
{[97]}\end{array}$ \\
\hline$\frac{\underline{\text { Bend, }}}{\text { Oregon }}$ & Demonstration & $\begin{array}{l}\text { United } \\
\text { States }\end{array}$ & (Unknown) & & & $\begin{array}{l}\frac{\text { AltaRock }}{\text { Energy, }} \\
\text { Davenport } \\
\underline{\text { Power }}\end{array}$ & $\begin{array}{c}\text { Permitting } \\
\text { (Mar 2010) } \\
{[98]}\end{array}$ \\
\hline Ogachi & $\mathrm{R} \& \mathrm{D}$ & Japan & (Unknown) & & $\begin{array}{c}1.0- \\
1.1\end{array}$ & & $\begin{array}{c}\mathrm{CO}_{2} \\
\text { experiments } \\
{[99]}\end{array}$ \\
\hline $\begin{array}{c}\text { United } \\
\text { Downs, } \\
\text { Redruth } \\
\end{array}$ & Commercial & $\begin{array}{c}\text { United } \\
\text { Kingdom }\end{array}$ & $10 \mathrm{MW}$ & Binary & 4.5 & $\begin{array}{l}\frac{\text { Geothermal }}{\text { Engineering }} \\
\underline{\text { Ltd }}\end{array}$ & $\begin{array}{c}\text { Fundraising } \\
\text { [100] }\end{array}$ \\
\hline $\begin{array}{c}\text { Eden } \\
\text { Project } \\
\end{array}$ & Commercial & \begin{tabular}{|c|} 
United \\
Kingdom
\end{tabular} & $3 \mathrm{MW}$ & Binary & $3-4$ & $\frac{\text { EGS Energy }}{\underline{\text { Ltd. }}}$ & $\begin{array}{c}\text { Fundraising } \\
\text { [101] }\end{array}$ \\
\hline
\end{tabular}

Table 4. Current enhanced geothermal projects $\{2009\}$ [68] 


\subsection{Hydro and tidal}

Hydro resources are well known and already widely developed. One thinks of Niagara Falls. There are many falls of this kind around the world, but some are too far from cities where the energy is needed.

\begin{tabular}{|c|c|c|c|}
\hline Country & Location & $\begin{array}{c}\text { Tidal height } \\
(\mathbf{m})\end{array}$ & $\begin{array}{c}\text { Power } \\
\text { (thousands of MW'S) }\end{array}$ \\
\hline Argentina & San Jose & 5.9 & 6.8 \\
\hline Australia & Cobequin & 12.4 & 5.3 \\
\hline \multirow{2}{*}{ Canada } & Cumberland & 10.9 & 1.4 \\
& Shepody & 10.0 & 1.8 \\
\hline India & Cambey & 6.8 & 7.0 \\
\hline UK & Severn & 15.0 & 8.6 \\
\hline \multirow{2}{*}{ US } & Knich Arm & 7.5 & 2.9 \\
& Turnequin & 7.5 & 6.5 \\
& Mezen & 9.1 & 7.0 \\
\hline \multirow{2}{*}{ Russia } & Tuger & - & 50.0 \\
\hline
\end{tabular}

http://en.wikipedia.org/wiki/Tidal_power, October 2007. [69]

Table 5. Some larger tidal power schemes under consideration around the world

Another water resource is the tides. In Table 5 above, is a list of 12 places around the world that had been judged particularly suitable for tidal technology. (See Table 5.)

The key quantity which tidal technology depends upon is the height of the tide. Four meters is minimal for a tide to have an economically worthwhile character to put in the necessary engineering work.

It must not be thought that we are limited to places in the world that are ideal for tides. A suitable spot only has to have a tide of more than 4 meters. An appropriate inlet and a place behind the inlet which can be made easily into a basin-like receptacle for the incoming water, to be held there until the basin is full at high tide, and then released after the tide has gone out, whereupon the energy is converted to electricity from the turbines which are being activated by the flowing water. Incoming water during rising tide can also be used but the usable power of such tides is less than those available during the tidal outflow.

\subsection{Would nuclear energy save us from global warming?}

\subsubsection{Fission reactors}

The domes which one sees around the country and the cooling towers comprise nuclear reactors and they work upon a process called fission. There is much drama behind the origin or the process of fission, a nuclear reaction of the type unknown before 1939. The fact that the discovery was made just before the beginning of WWII, made it all the more important, although everything to do with it (as I well remember being in England at the time), was deeply secret.

However, it's indisputable that the discovery of nuclear reactions was made by three Germans, Hahn, Meitner and Strassman. Moreover, these three, who were working in Berlin, were not seeking anything to do with nuclear energy. Uranium was a very heavy 
metal and the idea which Hahn et al had was that they would like to see if by bombarding it with neutrons, they could make a still heavier element, i.e. add something to the atomic weight.

Indeed, they did bombard uranium with neutrons but they found a result totally unexpected, in those days very peculiar, and the reaction that has altered the world and still does.

What they found was that the result of bombarding the uranium was to produce two other atoms, one called barium and the other a rare gas, called krypton. But, another thing was discovered, and turned out when the use was made militarily of the discovery, to be the key point: although they bombarded one neutron per uranium, they got back the strangely broken up atoms, and three neutrons.

Now the fission reaction which they found and which is now the basis of those towers that we see can be written in a chemical way as follows:

$$
{ }_{235} \mathrm{U}_{92}+{ }_{0} \mathrm{n} \rightarrow{ }_{139} \mathrm{Ba}+{ }^{44} \mathrm{Kr}+30 \mathrm{n}
$$

One of the most interesting things about the reaction was indeed the three neutrons, because, as those interested in an explosion rather than the peaceful use to provide heat only, saw it, the three neutrons from one could give rise to a spreading reaction of great force because after hitting a uranium atom with one neutron it could then strike 3, 6, 9, etc, and all this would happen in a very short time, providing a super great amount of heat.

But, every one of these reactions of the neutron with uranium was found to be remarkable in another way, instead of producing the heavier element that they sought, the researchers found that they had got two elements instead of one and this was indeed, therefore, a nuclear reaction. ${ }^{6}$

${ }^{235} \mathrm{U}_{92}$ an isotope of uranium was found in the mines when the researchers sought the kind of uranium they wanted. It turned out that there were two kinds of uranium. One had the atomic weight of 235 and this was rare, but the majority of the uranium atoms were of the isotope with the atomic weight of 238 and this was found to be non-fissile, i.e. it would not take part in the nuclear reaction which was found possible with U235.

As most people know, uranium is the heart of the atom bomb and of the peaceful use of nuclear reactions. In this short account, I'm going to neglect the military side completely (it is written up in dozens of books).

Great excitement attended the realization that we now had the ability of generating in a single nuclear reaction using the $\mathrm{U}_{235}$ an amount of heat which was of the order of magnitude 1 million times more than we were used to observing in a chemical, i.e. nonnuclear reaction.

For a few years (as I remember) there was a kind of feeling that a great climax had occurred and that all the future energies of the world was taken care of. People used to say "don't bother to turn off the lights in the future, energy will be so cheap" Where the doubts began is when calculations came out about how much uranium was in the ground, and could be

\footnotetext{
${ }^{6}$ Rutherford at Cambridge in England in 1919 had claimed that he and his coworkers had "split the atom" an early name for a nuclear reaction. His achievement was recognized at the time in these terms but the great excitement which came with the Hahn work in Germany was the three neutrons from one and the realization that it could give rise to an explosion of previously unrecognized force; and also (but latterly) it might, if tamed, be a very convenient source of a great deal of peaceful energy.
} 
recovered and the 235 kind of uranium extracted and how much would have to be rejected, namely the other isotope, the $\mathrm{U}_{235}$ kind. It seemed that counting only the USA, the supplies might last 100 years. As time has gone on, and other nations have found out how to do these reactions, and their enormous value, it's quite clear that the 100 years is by no means enough for jubilation when you understand that Russia, at least, and even India and China with their enormous populations, will all want to use the rather rare $U_{235}$ which is discovered to be active and take part in the basic reaction stated above.

Soon after the realization that there was not enough uranium to supply the world for a significant time (several hundred years) an idea was put forward which might solve the problem. Nuclear reactors (which have now been manufactured in numerous countries) take about twelve years each to build. If this astonishes the reader, it must be recalled that a nuclear reactor is not like some normal piece of machinery you could house in a factory. When one visits a nuclear reactor one sees a large spread of land covered with buildings, ending up with the famous dome and the cooling towers.

Apart from what you see, there are of course, in the building stage, many things done to protect the workers from radiation and to minimize the possibilities of an accident which could even cause an explosion. ${ }^{7}$

So let us leave the fission aspect of nuclear reactions here and now. We can say that it has been a success (the only part of nuclear science so far which has been completely successful) but it simply will not do for the further future. ${ }^{8}$

\subsubsection{Breeding}

It has been clear from what is stated above that when the $U_{235}$ is extracted from the natural uranium found in the ground, a great deal of uranium remains over. Of course this is the non explosive U238 and it didn't take long for nuclear physicists to see that there might be a way of converting the inactive U238 to undergo conversion which could lead to a series of nuclear reactions, and finally to a stable (explosive) isotope of great amount.

The suggested process of breeding was to start with plentiful U238 and from it to form U239.

The U239 then decays spontaneously to Np239 + $₫$

After this, there is still a third reaction in the sequence in which Np239 becomes Pu239, namely plutonium, and this is fissile.

Thus, when these thoughts were published or became well known, it was thought the problem of our energy needs had been solved. The U238 was in abundance, in wastes that came about when the U235 was extracted, so that there was now no problem about having plenty of uranium. The above reaction to form plutonium had indeed to be carried out, but there was no more problem with the amount of Uranium and therefore for a brief time,

\footnotetext{
7 Until after 2000, it was always feared that a meltdown would occur and that a peaceful heat producing reaction will become a menace and perhaps even kill large numbers of people. We only know of one such incident, that at Chernobyl but the nuclear fire and partial explosion which occurred there has caused thousands of death in Russia itself, and damage to people in most parts of the northern hemisphere.

8 For example in order to supply the USA alone with nuclear reactors, we would have to build 1,800 of them at 12 years each. Of course I understand several can be built simultaneously but to supply our own country with them whilst other countries are also building them, and planning to use the same uranium, simply makes the idea of a nuclear-fission pathway impractical.
} 
there was jubilation again, and again thought that the great problem of the future of energy was a battle won.

Unfortunately however, the question of the efficiency of these reactions of the breeding process had not been taken into account. The early, happy workers thought that these reactions should be carried out "round about" $100 \%$ efficient. So, if you knew how much U238 there was in the world, it was simple to calculate how much plutonium could be made, and consequently, how much nuclear energy we would have for our energy supply.

The history of the breeding process has been a series of disappointments. At first the efficiency was about $1 \%$, and over the years with French leadership, the amount of efficiency has grown to $5 \%$. But it gives us hope (that this could be improved to $10-20 \%$, and if worse comes to worse, we will have nuclear energy for at least 200 years more).

\subsubsection{Fusion}

When it was known that the efficiency of the breeding process was so low, nuclear scientists turned towards another idea that, as we shall see, demanded of remarkable new technology. Thus, what we have been discussing is nuclear fission energy, and what I am now going, very briefly, to survey is fusion, namely the idea that two atoms when brought together with sufficient force, can fuse together instead of breaking up, and if this is done in a nuclear, rather than a chemical way, then great energies could also be released and finally might be tamed in such a way that they could be used in peaceful ways.

The first basic idea here was to use two of the second isotope of hydrogen, mainly deuterium. Calculations showed that if it were possible to raise the temperature of deuterium atoms to some previously unrealized temperature, namely that of the sun (!), then this tremendous heat would cause the two deuterium atoms to fuse together and form the rare gas helium.

Again, there was jubilation, although it was realized even at the beginning that two tasks faced the engineers. One was to obtain the colossal heat and temperature, but the $2^{\text {nd }}$ was the greater difficulty, how could you contain it?

It seemed ludicrous to suspect you could contain something inside another something that was so hot that it would be a greater temperature than the sun itself.

Nuclear scientists are both brave, and daring. They did indeed advance an idea that seemed, at first, to be the solution. Yes, it was not possible for anything to touch the reacting particles, but how about a magnetic field?

Magnetic fields don't break things down but with the atoms in the reaction being in the form of ions, a strong magnetic field engineered to have the shape of a bottle, will theoretically, contain the deuterium ions and when they struck each other, in collisions, at the enormous temperatures we are speaking about $\left(\begin{array}{lll}10^{8} & 0 & K\end{array}\right)$ then surely there would be helium produced and a great deal of heat.

You probably understand by now that I'm going to tell you that it didn't work, and with the space available I can only tell you that it was never successful to keep the deuterium inside the "bottle", it always leaked out.

Russians, the US, the British all tried for years to make this work, and the Russians even gave it a name: TOKAMAK, which is the Russian name for bottle, reversed.

Undaunted, the nuclear scientists came out with another idea, maybe even more fantastic than the first. This time they mixed together small amounts of deuterium and tritium and kept them at very low temperatures so that they remained frozen. 
Imagine now, a small tower on top of which sits the tiny sphere of mixed deuterium and tritium. The objective is to make the deuterium and tritium fuse together and produce a new particle.

The theoretical concept was to do this with a laser, and a laser of tremendous power, far greater than anything formerly engineered. ${ }^{9}$

Of course the idea was that when the laser stuck the particles, the force of the collision would make the deuterium and tritium fuse together. It was found, however, that the laser that had been built of sensational power was still not enough to fuse the two atoms.

Another difficulty was found but not solved. We're talking about small spheres of deuterium and tritium and thinking they might power the world??

But the physicists had an idea about this, too. The small sphere was simply a working model and if the laser had been powerful enough to make the atoms fuse in it, the engineers were going to drop particle after particle down from the tower and as each particle dropped the laser would strike again and so if you made 100 drops per minute you would get a very considerable amount of energy (remember we're talking nuclear energy, about 1 million times more than chemical energy)

It's not only we in the USA who are held up and very frustrated by the failure of these attempts to supplement and supply something which could last in nuclear energy for many years.

The real thing which bothers the legislators is the amount of money this is all costing. I think that the sum is not often spoken about but it leaks out to us that if you add the Russian expenditures to our own, more than one billion dollars per year has been expended on research into fusion and most of the people outside the USA believe the best thing to do is to stop wasting money.

Hence I think that I can answer the question with which I began this section of this article, and that is to say that I think that nuclear reactions in the future is a very dicey and unsuccessful way to obtain energy without pollution and most of the thoughts of others is the best thing to do is to stop and think before another billion is spent.

\subsection{Mediums of energy}

Apart from having a certain energy source (wind, solar, and hot rock geothermal being prominent as the first replacements of fossil fuels) all the renewable energy sources, e.g. wind, may need a medium which can couple with the source to produce energy in a form suitable for households, factories and military.

\subsection{Electricity: the principal energy medium}

This is the obvious medium for new, clean energy and will serve in most situations. We are all familiar with what is called "the grid" which consists of cables carrying energy from sources where the electricity is produced, e.g. solar, wind, geothermal, and bringing it to places where it is needed.

At present, cables carrying 100,000 volts are used. It is important to realize that the potential that is used in the AC transmission of electricity over long distances in cables decides the length of the cable that must not manifest too much IR drop, - wasted energy.

\footnotetext{
${ }^{9}$ By happenstance, I visited the site where the laser was housed just after being shown to be a failure again. It was a large building, especially built to contain the laser.
} 
Until the 1960's long distance cable lines were run at 30,000 volts, but this has been changed to 100,000 volts. The difference is easily calculated because the heating effects, i.e. energy lost in passing an electric current through a cable is given by the equation:

$$
\text { Lost heat }=\mathrm{I} 2 \mathrm{R}
$$

Hence, if one increased the E, one decreases the I, for the same power, EI and therefore the energy lost in heat is decreased.

There is a limit to how far this raising of the volts can go, because the AC nature of the electricity means that cables radiate and could provide a health hazard to those sufficiently near them. At present, the limit is 100,000 volts.

\subsection{Is room temperature super conductivity a possibility?}

Were we to have virtually no resistance in cables, we should be able to send energy unlimited distances without loss of energy.

How far along are we with superconductivity research?

The answer is that unexpected strides have been made in this area, and that coming from a situation in which superconductivity was to be observed only near to the absolute zero of temperature. Superconductivity has become something that is still far from large-scale practical application but there are now situations where the working temperature is above that of liquid nitrogen and might be (economically) usable.

In Table 6 a number of superconductors are portrayed as of the present time, 2010, and it's visible that the substances that has been found to have superconducting properties and to allow the temperature to rise as high as $134 \mathrm{~K}$, are complicated substances.

The one that has the highest temperature, which performs as a superconductor there is:

$$
\mathrm{HgBa}_{2} \mathrm{Ca}_{2} \mathrm{Cu}_{3} \mathrm{O}_{8} \text {. }
$$

There are other fundamental problems in realizing practical super conductivity: thus, if the current passing exceeds a carbon value, the phenomenon appears to fade off.

So, there is a long way to go, but the goal here is so important that we can expect a good deal of National Science Foundation funding.

\subsection{Hydrogen: could it be a clean replacement for $\mathrm{CO}_{2}$-producing gasoline?}

The clean hydrogen could be a medium of energy was proposed in 1971 \{John O'M. Bockris\} [71]. At this time it was feared that smog could develop over cities with insufficient winds to clear it. So, one of the solutions suggested was that the medium by which we drive our cars should be changed from gasoline to hydrogen, so automotive exhausts would be changed from the material causing smog to pure water vapor. Further, the use of hydrogen would make fuel cells an immediate source of electricity as fuel cells convert chemical to electrical energy at twice the efficiency of batteries.

Since the early seventies there have been changes that affect the need for hydrogen as a medium. The main one has already been mentioned: the potential in the cables for long distance transmission of electricity has been raised, thus extending the practical use of the cables by lessening the energy lost in heat.

The need for storage of large amounts of electricity increases when we think of supplying

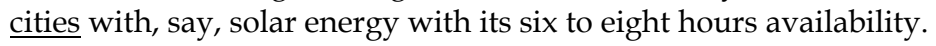




\begin{tabular}{lc|c|c|c}
\multicolumn{1}{c}{ Formula } & Notation & $\boldsymbol{T}_{\mathbf{c}}(\mathbf{K})$ & $\begin{array}{c}\text { No. of Cu-O planes } \\
\text { in unit cell }\end{array}$ & Crystal structure \\
\hline $\mathrm{YBa}_{2} \mathrm{Cu}_{3} \mathrm{O}_{7}$ & 123 & 92 & 2 & Orthorhombic \\
$\mathrm{Bi}_{2} \mathrm{Sr}_{2} \mathrm{CuO}_{6}$ & $\mathrm{Bi}-2201$ & 20 & 1 & Tetragonal \\
$\mathrm{Bi}_{2} \mathrm{Sr}_{2} \mathrm{CaCu}_{2} \mathrm{O}_{8}$ & $\mathrm{Bi}-2212$ & 85 & 2 & Tetragonal \\
$\mathrm{Bi}_{2} \mathrm{Sr}_{2} \mathrm{Ca}_{2} \mathrm{Cu}_{3} \mathrm{O}_{6}$ & $\mathrm{Bi}-2223$ & 110 & 3 & Tetragonal \\
$\mathrm{Tl}_{2} \mathrm{Ba}_{2} \mathrm{CuO}_{6}$ & $\mathrm{Tl}-2201$ & 80 & 1 & Tetragonal \\
$\mathrm{Tl}_{2} \mathrm{Ba}_{2} \mathrm{CaCu}_{2} \mathrm{O}_{8}$ & $\mathrm{Tl}-2212$ & 108 & 2 & Tetragonal \\
$\mathrm{Tl}_{2} \mathrm{Ba}_{2} \mathrm{Ca}_{2} \mathrm{Cu}_{3} \mathrm{O}_{10}$ & $\mathrm{Tl}-2223$ & 125 & 3 & Tetragonal \\
$\mathrm{TlBa}_{2} \mathrm{Ca}_{3} \mathrm{Cu}_{4} \mathrm{O}_{11}$ & $\mathrm{Tl}-1234$ & 122 & 4 & Tetragonal \\
$\mathrm{HgBa}_{2} \mathrm{CuO}_{4}$ & $\mathrm{Hg}-1201$ & 94 & 1 & Tetragonal \\
$\mathrm{HgBa}_{2} \mathrm{CaCu}_{2} \mathrm{O}_{6}$ & $\mathrm{Hg}-1212$ & 128 & 2 & Tetragonal \\
$\mathrm{HgBa}_{2} \mathrm{Ca}_{2} \mathrm{Cu}_{3} \mathrm{O}_{8}$ & $\mathrm{Hg}-1223$ & 134 & 3 & Tetragonal
\end{tabular}

Origin: Superconductivity, Wikipedia, Free Encyclopedia, 2010.

Table 6. [70] Critical temperature $\left(T_{\mathrm{c}}\right)$, crystal structure and lattice constants of some high- $T_{\mathrm{c}}$ superconductors

Here, any plans which will be put into practice to replace gasoline must be obviously non$\mathrm{CO}_{2}$ producing, and will include the ones already mentioned, e.g. wind, solar, and enhanced geothermal.

On the other hand, at a given time, and also the wind characteristics so that one need not worry about hours or days of irregularity but it is necessary to have stores for solar energy and wind energy for the big cities, these stores will have to be large.

Here, the virtues of hydrogen (for storage) are attractive. It is easy to produce from electricity, the form in which the solar and wind energy is most immediately available, and so large stores of hydrogen, at the moment, is the main way we hope to overcome the difficulty of transfer and storage of the cheapest of our renewable clean energies, no Global Warming.

A world which is set up to use solar and wind, together with appropriate storage for the big cities, would lead to a world without Global Warming by means of $\mathrm{CO}_{2}$.

Of course, we look toward to a hope that we will be able to rely upon superconductivity. Here a breakthrough occurred in 1986, when, for the first time, it was possible to prove superconductivity in materials that retained this property above the boiling point of liquid nitrogen, $77 \circ \mathrm{K}$. (See Table 6).

\subsection{Approximate estimate of the cost of changing to an inexhaustable energy from fossil fuels}

It is when we look at the financial side of the big change, that resistance looms high in one's mind.

The first thing we could do to get over the great tax hump which confronts us in the near future is to reduce the energy per person which is used by American citizens. ${ }^{10}$ Certainly,

${ }^{10}$ About twice that used by Europeans (as in e.g., England, France, Italy, et cetera.) 
there are now countries in the Middle East where the citizen per person needs are more than $10 \mathrm{KW}$, the amount that Americans say they need.

In seeking some rationale for aiming our estimate of the renewable energy needed, $6 \mathrm{~kW}$ is the equivalent power per person we shall assume. ${ }^{11}$

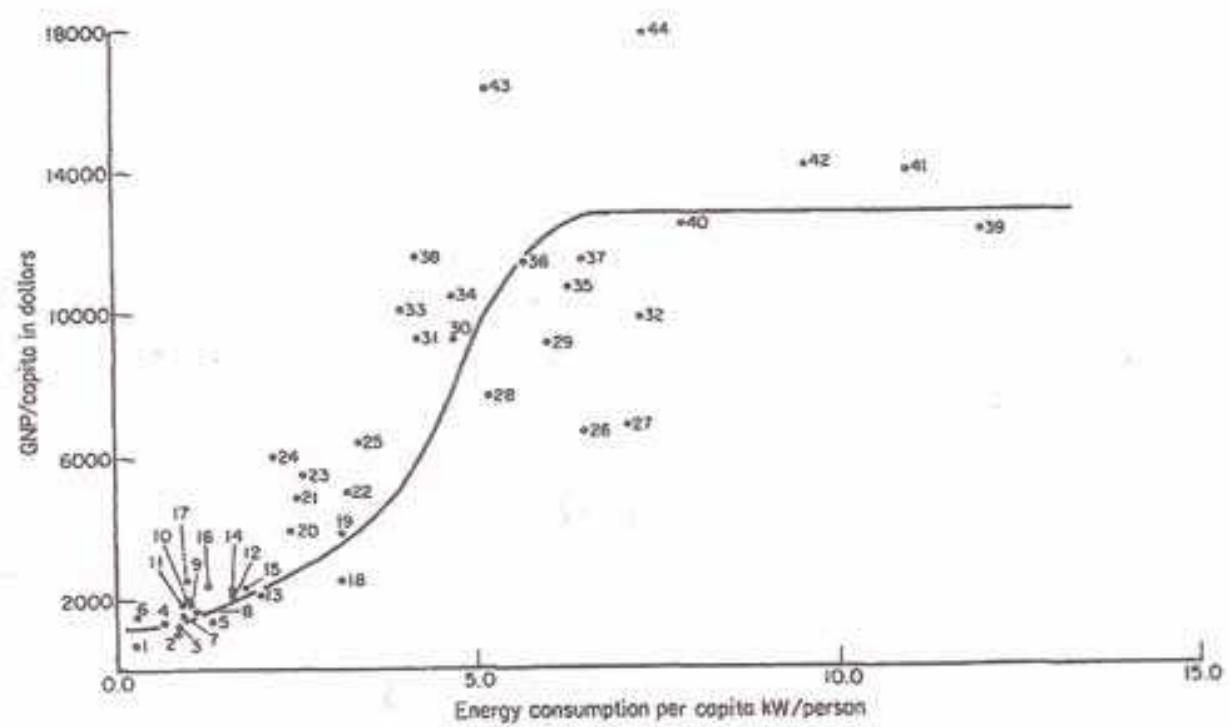

Fig. 1 EEnergy consumption per capita relationship with GNP per capita. 1. Iwory Coast, 2, Costa Rica, 3. Turkey, 4. Tunisia, 5. Jamaica, 6. Paraguay, 7. Ecuador, 8. Jordan, 9. Malaysia, 10. Chile, 11. Brazil, 12. South Korea, 13. Argentina, 14. Portugal, 15. Mexico, 16. Algeria, 17. Uruguasy, 18. South Africa, 19. Venezucla, 20. Greece, 21. Spain, 22. Ireland, 23. Isract, 24. Hong Kong, 25. Italy. 26. Singapore, 27. Trinidad \& Tobago, 28. New Zealand, 29. Belgium, 30. United Kingdom, 31. Austria, 32. Netheriands, 33. Japan, 34. France, 35. Finland, 36. West Germany, 37. Australia, 38. Denmark, 39. Canada, 40. Sweden, 41. Norway, 42. United States, 43. Switzerland, 44, Kuwait.

Fig. 25.\{ P. Dandapani, 1987\} [72]

With this limiting assumption, and conscious of the energy difficulties that face us, let us try for a very approximate 2010 cost estimate.

We start with a population of 300 million people, i.e. $3.10^{8}$ and we are going towards a $6 \mathrm{~kW}$ per person economy. This refers to the energy of all functions of the civilization, including for the USA, the heaviest items expenditure are on military operations, twice the per head expenditure of citizens in the main European powers.

What is the average cost per kw of wind or solar energy that, on average, would supply energy at the rate of $1 \mathrm{~kW}$. The amount varies from estimate to estimate, but on the whole, $\$ 5,000$ per $\mathrm{kW}$ is a median value. Thus, the value for the USA would be: $\mathbf{3 . 1 0 8} \mathbf{6 . 5 0 0 0}$.

This is $\$ 9$ trillion.

\footnotetext{
${ }^{11}$ Comparison with the income and living standard of other nations, an interesting result arises. It appears that until around $6 \mathrm{~kW}$ per person, the increase in living standards increases exponentially with increase in income. However, around $6 \mathrm{~kW}$, there is no further increase in living standard. This presents a big question in Sociology.
} 
Over what time would we have to pay this very large cost? Here, it's going to only be possible to make an arbitrary assumption that we could pay it over fifty years. Taxation could be used to discourage the population from using $\mathrm{CO}_{2}$ producing energy and encourage them in the direction in the new $\mathrm{CO}_{2}$ free energy.

The cost of the 9 trillion will sink to 0.18 trillion per year or 180 billion per year if paid over fifty years.

Sums as large as this are difficult to comprehend, but it may be helpful to know that we spend $\$ 900$ billion per year (four times more) operating our armed forces.

\subsection{The cost of hydrogen as an energy storage medium}

In some cases, sources of hydrogen will originate away from the place where the energy is needed. Further, if it comes from wind and solar, the sources will be from storage systems (although if we introduce enhanced geothermal the supply will be stable).

The principal ancillary costs of storage (1.70 / GJ) transportation of the energy (3.00 / GJ) and finally, distribution. By "distribution" Tappan Bose and Malbrunot charge 15.00 / GJ \{2006\} [73]. This latter cost seems high even if the main cost of distributing the hydrogen in the form of electricity is passing through a fuel cell and assuming an efficiency of 50 percent. This will cost around $\$ 9.60$ / GJ to get the hydrogen after storage back to electricity.

To obtain the cost of raw hydrogen, the after costs of which we are discussing, let us start by taking \$22 / GJ as the cost of hydrogen from wind energy by means of the electrolysis of water at room temperature. 12

Thus, with this value for the raw hydrogen, the cost of electricity of stored hydrogen at distance from the source would be about $\$ 37.00$ / GJ.

\subsection{The cost of liquifying hydrogen}

The attitude taken by most to liquefying gaseous hydrogen is that it will be too expensive, because liquefaction of such low temperature needed is inefficient in a Carnot sense. The hydrogen boiling point is $20.28 \circ \mathrm{K}$ \{E. Wiberg, N. Wiberg, et al, 2001\} [74].

Now, Tappan Bose and Malbrunot have come up with a different view. They point out that the cost of liquefying hydrogen is not so out of reach when one considers the comparison should be made not with raw hydrogen from the plant but delivered hydrogen which the French Canadians gives as $\$ 40-\$ 48 / G J$. Thus, using the liquid saves several things, and these are transportation costs, and of course, there is no need for compression, storage and use of the fuel cell.

There are several costs arrived at by Tapan Bose and Malbrunot \{2006\} [73] and the ones with which we are going to use as a benchmark is that for a GJ of gaseous hydrogen, $\$ 48$ ?GJ. (Compare the known cost of gaseous hydrogen, raw, at the electrolyzer of $\$ 20$, - the range of cost goes from $\$ 16$ to $\$ 26$ depending on the temperature of the electrolysis.)

\footnotetext{
12 The older means of obtaining hydrogen from this system reforming of natural gas is no longer admissible if we are going to ban $\mathrm{CO}_{2}$ from entering our atmosphere, we cannot use these low cost methods of producing hydrogen and must resort to electricity. The cost of this is a longer story, but optimistic figures have been given by the wind energy association of America $(.02 \mathrm{c} / \mathrm{kWh})$ and by the group that has sent helicopters up to 15,000 feet to milk the winds there. $(.02 \mathrm{c} / \mathrm{kWh})$
} 


\begin{tabular}{|l|l|l|}
\hline $\begin{array}{l}\text { Conversion machinery } \\
\text { producing electricity and } \\
\text { hydrogen. } \\
\text { Paid over fifty years. }\end{array}$ & $\begin{array}{l}9.10^{12} \\
30010^{9} / \text { year }\end{array}$ & $\begin{array}{l}\text { Conversion machinery assumed } \\
\text { built over twenty-year period. If } \\
\text { capital cost paid at same rate, cost } \\
\text { would be } \$ 250.10^{9} \text { per year (about } \\
1 / 2 \text { the cost of the U.S. Military } \\
\text { budget). }\end{array}$ \\
\hline $\begin{array}{l}\text { Raw Hydrogen from } \\
\text { Methane }\left(\mathrm{CO}_{2} \text {-free). }\right.\end{array}$ & $\$ 9.50 / \mathrm{GJ}$ & Process described in reference [75]. \\
\hline Electrolysis, raw, at plant. & $\$ 14.50 / \mathrm{GJ}$ & $\begin{array}{l}\text { Cost of electricity assumed (2008) } \\
\text { is } \$ .03 \text { c.kWh, } \$ .02 \mathrm{ckWh} \text {, tested. } \\
\$ .04 \mathrm{c} / \mathrm{kWh} \text { from Nano-Solar [76] }\end{array}$ \\
\hline $\begin{array}{l}\text { Electrolysis, raw, at plant, } \\
1000^{\circ} \mathrm{C}\end{array}$ & $\$ 12.26 / \mathrm{GJ}$ & $\begin{array}{l}\text { Uses } \mathrm{U}_{3} \mathrm{O}_{8} \mathrm{Y}_{2} \mathrm{O}_{3}, \text { membrane, Bevan, } \\
{[77] .}\end{array}$ \\
\hline $\begin{array}{l}\text { Ancillary costs of storage, } \\
\text { transport, and delivery, } \\
\text { (after electrolysis). }\end{array}$ & $\$ 25.00 / \mathrm{GJ}$ & $\begin{array}{l}\text { Involves storage, transfer, and } \\
\text { delivery. }\end{array}$ \\
\hline $\begin{array}{l}\text { Liquid } \mathrm{H}_{2} \text { (including cost of } \\
\text { electrolysis). }\end{array}$ & $\$ 51.00 / \mathrm{GJ}$ & $\begin{array}{l}\text { This is } 25 \text { percent increase in } \\
\text { passing from gaseous to liquid is } \\
\text { less than that imagined. }\end{array}$ \\
\hline
\end{tabular}

Table 7.

\subsection{Hydrogen would be a dangerous fuel to handle}

Hydrogen is a dangerous fuel, but the degree of danger has to be compared with that of a reasonable alternative, natural gas.

What is different with hydrogen that makes it more dangerous than natural gas that the mixture of hydrogen and air becomes explosive over a wider range of compositions than with natural gas.

Thus, one can imagine a practical example of hydrogen leaking out into an enclosed space, such as a garage, versus natural gas in the same situation. Here, the leaking hydrogen will be more dangerous than the leaking natural gas because, the garage atmosphere will become explosive, far more easily with natural gas.

These dangers may be lessened by the fact that the power of the hydrogen explosion is 4 times less than that of a natural gas.

Another aspect of the hydrogen versus natural gas comparison is that the burning of hydrogen in the air is a straightforward matter of the burning gas going upwards (see Figure 26). On the other hand, a car on fire with gasoline is extremely dangerous with the fire spreading and many dangerous vapors of organic compounds that are being consumed by the burning gas. The appearance of the car undergoing a natural gas explosion versus a car undergoing a hydrogen explosion, is impressively in favor of the hydrogen.

\subsection{The so-called "liquid hydrogen" \{G. Olah, et al, 2006\} [78]}

Hydrogen seemed the number one solution as a medium to some of our pollution problems and those who support this idea may be excited to know that Global Warming is attributed to automotive exhaust gases, another strong indication in favor of the use of hydrogen as an automotive fuel (with lower cost). 


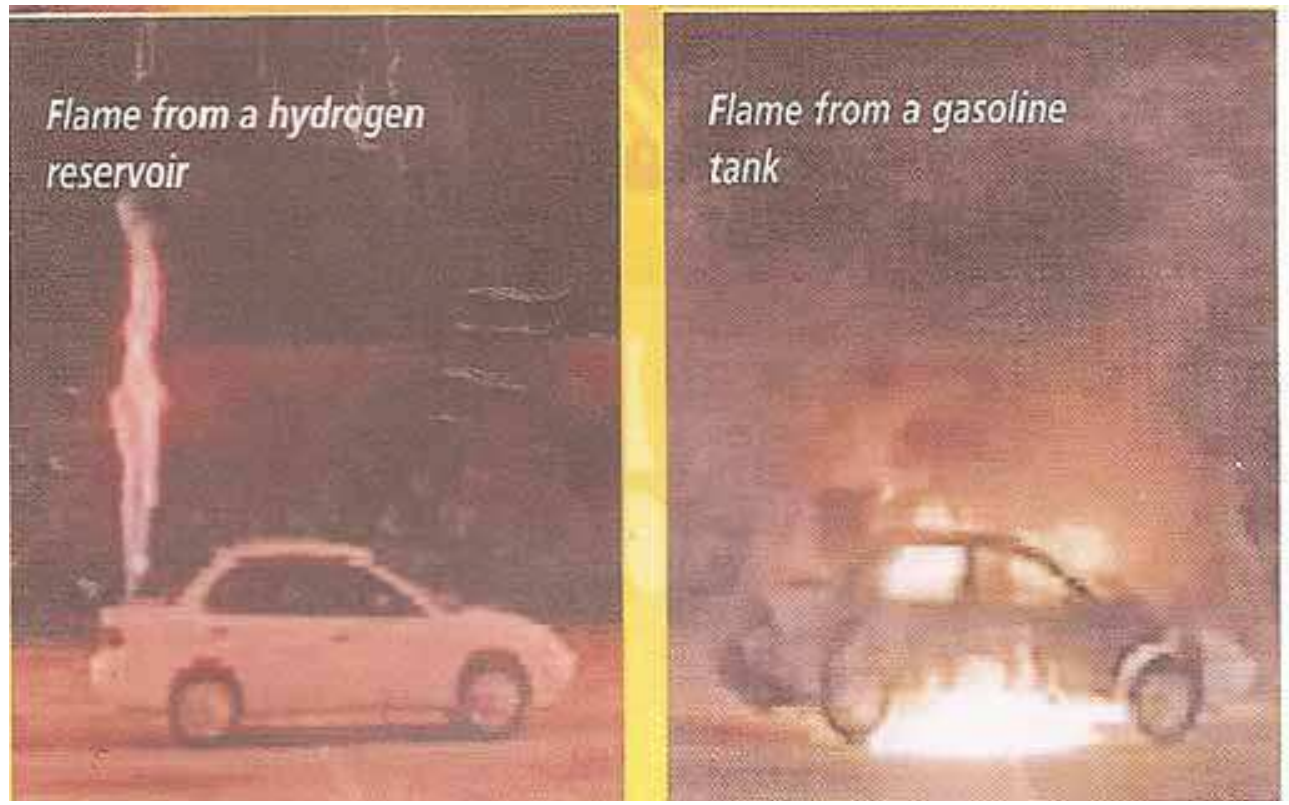

Fig 26. Tapan Bose and Pierre Malbrunot, et al, Hydrogen: Facing the Energy Challenge of the 21st Century, John Libby Eurotext, UK, December 2006, p.59.

A large-scale use of a Hydrogen Economy has grown as indicated by the size of the International Journal of Hydrogen Energy. In the early 1970's a single thin volume every two months, the journal is a signal of its use but now in 201, it is published twice per month in thick issues.

Although the cost of making a GJ of hydrogen from water by means of electrolysis from wind is reasonable and at room temperature is about $\$ 22.00$ per GJ, this leaves out several steps that would have to be accepted by anyone who uses hydrogen in a practical situation.

For one thing, hydrogen is a gas and has to be stored, piped and transmitted and reconverted to electricity.

The total of these additional costs on top of what the electrolyzer gave, means as much as $\$ 40.00$ / GJ, or in Tappan, Bose \& Malbrunot, \$48.00/GJ.

\subsection{Should "liquid hydrogen" be cheaper?}

Olah suggested [78] "Liquid Hydrogen" as a nickname for methanol, but this does not deal with the most important point of going to hydrogen. It does not form $\mathrm{CO}_{2}$ pollution.

The content of a suggestion which may solve the hydrogen cost problem comes out of a development of Olah's idea of a methanol economy but has within it a significant difference and this is what I wish to represent here.

Thus, the methanol economy as written by Olah and colleagues \{2006\} [78] gives helpful information about the properties of methanol as a medium of energy (Table 8). Thus, storage and transport of methanol would be little different from what the world uses in its treatment of gasoline.

Transportation, too, would no longer need new cars or a new infrastructure! 
In fact, replacing gasoline with methanol would allow us to continue our present economy with little difference. However, there is one thing missing: how can we use methanol as a medium of energy if it would still cause Global Warming?

\begin{tabular}{|c|c|c|c|c|}
\hline Property & Electricity & Methanol & $\mathrm{H}_{2}$ Liquid & $\mathrm{H}_{2}$ Gas \\
\hline $\begin{array}{l}\text { Methods of } \\
\text { preparation }\end{array}$ & $\begin{array}{l}\text { Photovoltaic; or } \\
\text { heat engine, et } \\
\text { cetera. }\end{array}$ & $\begin{array}{c}\text { Photosynthetic; or } \\
\mathrm{CO}_{2} \text { from rocks }+ \\
\mathrm{H}_{2} \text { from water. }\end{array}$ & $\begin{array}{c}\text { heat } \\
\mathrm{H}_{2} \mathrm{O} \rightarrow \mathrm{H}_{2} \\
\text { Elec } \\
\text { Liq. } \mathrm{N}_{2} \\
\rightarrow \mathrm{H}_{2} \text { (Low T) } \\
\text { Expansion } \\
\rightarrow \mathrm{H}_{2} \text { (liquid) }\end{array}$ & $\begin{array}{c}\text { heat } \\
\mathrm{H}_{2} \mathrm{O} \underset{\text { elec }}{\rightarrow} \mathrm{H}_{2}\end{array}$ \\
\hline $\begin{array}{l}\text { Mixes with } \\
\text { water }\end{array}$ & Not applicable & $\begin{array}{l}\text { Complex; but in } \\
\text { gasoline forms } \\
\text { two immiscible } \\
\text { layers if water } \\
\text { present }\end{array}$ & Not applicable & Not applicable \\
\hline Corrosion & Zero & $\begin{array}{l}\text { Significant } \\
\text { problem }\end{array}$ & Zero & Zero \\
\hline $\begin{array}{l}\text { Flame speed } \\
\text { Flame } \\
\text { temperature }\end{array}$ & $\begin{array}{l}\text { Not applicable } \\
\text { Not applicable }\end{array}$ & $2900^{\circ} \mathrm{C}$ & $\begin{array}{c}306 \mathrm{~cm} \mathrm{sec}^{-1} \\
20500^{\circ} \mathrm{C}\end{array}$ & $\begin{array}{c}306 \mathrm{~cm} \mathrm{sec}^{-1} \\
2050^{\circ} \mathrm{C}\end{array}$ \\
\hline Luminosity & Not applicable & Fair & Poor & Poor \\
\hline $\begin{array}{l}\text { Production of } \\
\text { pollutants on } \\
\text { combustion }\end{array}$ & Zero & $\begin{array}{c}\mathrm{CO}+\text { Aldehydes } \\
\text { worse than } \\
\text { gasoline } \sim \mathrm{NOX} \\
\text { worse than } \mathrm{H}_{2}\end{array}$ & Zero & Zero \\
\hline Use in fuel cell & Not applicable & $\begin{array}{c}\text { Poor compared } \\
\text { with } \mathrm{H}_{2} \text { better } \\
\text { than oil } \\
\end{array}$ & The best & The best \\
\hline $\begin{array}{c}\text { Compatible } \\
\text { present IC } \\
\text { Engine } \\
\end{array}$ & Not applicable & $\begin{array}{l}\text { Good. Some } \\
\text { redesign } \\
\text { necessary } \\
\end{array}$ & $\begin{array}{c}\text { Good. Fuel } \\
\text { injection needed }\end{array}$ & $\begin{array}{c}\text { Good. Gas } \\
\text { storage }>300 \\
\text { miles ok Li cells }\end{array}$ \\
\hline Storage & $\begin{array}{c}\text { Difficult in large } \\
\text { amounts }\end{array}$ & Easy & $\begin{array}{c}\text { Liquefaction } \\
\text { costs \$2-\$3 per } \\
\text { MBTU }\end{array}$ & $\begin{array}{c}\text { Compressed gas } \\
\text { in tank. }\end{array}$ \\
\hline Transmission & $\begin{array}{l}\text { Too expensive } \\
>1000 \mathrm{~km}\end{array}$ & $\begin{array}{c}\text { Costs slightly less } \\
\text { than h2 in } \\
\text { pipeline }\end{array}$ & $\begin{array}{c}\text { Costs } 25 \%> \\
\text { methanol }\end{array}$ & $\begin{array}{l}0.2 \text { cents per } \\
1000 \mathrm{~km}\end{array}$ \\
\hline $\begin{array}{l}\text { Biological } \\
\text { hazard }\end{array}$ & $\begin{array}{c}\text { Safety } \\
\text { preventions well } \\
\text { practiced }\end{array}$ & $\begin{array}{c}\text { Toxic; air } \\
\text { pollution caused } \\
\text { by large spills }\end{array}$ & Zero & Zero \\
\hline $\begin{array}{l}\text { Consumer } \\
\text { acceptance } \\
\text { before facts } \\
\text { realized }\end{array}$ & Excellent & Very good & Poor & Poor \\
\hline
\end{tabular}

Table 8. electricity, methanol, and hydrogen compared as fuels [79] 
Consider the formula of methanol, $\mathrm{CH}_{3} \mathrm{OH}$, it can be found from:

$$
3 \mathrm{H}_{2}+\mathrm{CO}_{2} \rightarrow \mathrm{CH}_{3} \mathrm{OH}+\mathrm{H}_{2} \mathrm{O}
$$

Instead of making methanol with ordinary $\mathrm{CO}_{2}$ and hydrogen we take the trouble to get the $\mathrm{CO}_{2}$ we need firstly from the atmosphere. If we avoid momentarily the problem of how to get the $\mathrm{CO}_{2}$ from the atmosphere in large amounts, then we can combine $\mathrm{H}_{2}$ and $\mathrm{CO}_{2}$ directly to form methanol \{S. Ono, et al, 1986; I. Yasudaa, U. Shiraski, 2007\}[80, 81, 82]. This is a process that has been worked on in Japan.

Methanol formed via $\mathrm{CO}_{2}$ from the atmosphere produces no net greenhouse warming because although when we burn it to produce energy it does inject $\mathrm{CO}_{2}$ into the atmosphere, we already got $\mathrm{CO}_{2}$ in the methanol from the atmosphere so no extra $\mathrm{CO}_{2}$ enters the atmosphere when we burn methanol created with in from the atmosphere.

Hence, there would be NO increase in Global Warming in a methanol economy if the one great exception towards what Olah said is made, that the $\mathrm{CO}_{2}$ that is part of the makeup of the methanol, comes from the atmosphere itself.

Let us count the advantages that would occur if we did have methanolat.

As far as transportation is concerned, we would go to a different gas tank and pour this special methanol into their cars rather than gasoline. Over a period of, say, fifteen years, the whole country would be converted and methanol would become a general medium of energy, and the problem of Global Warming would have been solved.

Another advantage is that we would not necessarily have to change our manufacturing. We could go on with our present fleet of cars, but now run them on methanol made from the atmosphere. There would be no rebuilding of the infrastructure. Of course, we firstly have to obtain $\mathrm{CO}_{2}$ from the atmosphere.

\subsection{Methods for obtaining $\mathrm{CO}_{2}$ from the atmosphere}

So far, in this account of "liquid hydrogen" we have stated the virtues of what would happen, were we to have methanol formed with $\mathrm{CO}_{2}$ from the atmosphere. A Methanol Economy with the methanol from the atmosphere now will be like having hydrogen with the difference of no longer dealing with a gas, having to store it, transport it, reconvert it to methanol and use that more or less as we use gasoline.

The first problem, then, is to collect the wind and devise how to bring a large stream of air to the machine, and one of the answers which comes to mind is to figure on (admittedly a supposition) that there will be a good deal of energy made from wind in our future.

The next thing is to suggest that the wind that you wish to collect will come from a stream of wind to electricity generator in a wind belt.

Now then, suppose the wind sweeps through the wind generator, does its kinetic work there, and sweeps on at present it's just allowed to dissipate itself in the air behind it and has no further purpose.

\section{WIND GENERATOR METHOD}

We would collect the wind behind the wind generator in a wide mouthed tube, decreasing the diameter of the tube, until it's down to say $5^{\prime}$.

In this still a very wide tube, into which we put highly powdered magnesium oxide. We heat this $\mathrm{MgO}$ at $350^{\circ} \mathrm{C}$ in the tube containing the oxide. We keep the powdered magnesium oxide in small particles, not filling the tube, but when the wind comes through it, there will 
be good contact between the magnesium oxide particles and the wind. At this appropriate temperature, a combination will occur and magnesium carbonate will result.

Of course, we have to do experiments and find out how long the tube has to be to get say $90 \%$ reaction of $\mathrm{CO}_{2}$ and $\mathrm{MgO}$, and furthermore, what should be the minimal temperature for a 95 percent dissociation (with catalyst).

What we are planning is a batch process and at the end of the first period, the flow of the air is suspended, and the magnesium carbonate now in the tube, is heated to more than $700^{\circ} \mathrm{C}$. The magnesium carbonate breaks down and goes back to oxide, and a result of this is that $\mathrm{CO}_{2}$ is produced, and is in a stream which is what we need, and can be piped off to a side circuit where it is brought into contact with a storchiometric amount of hydrogen.

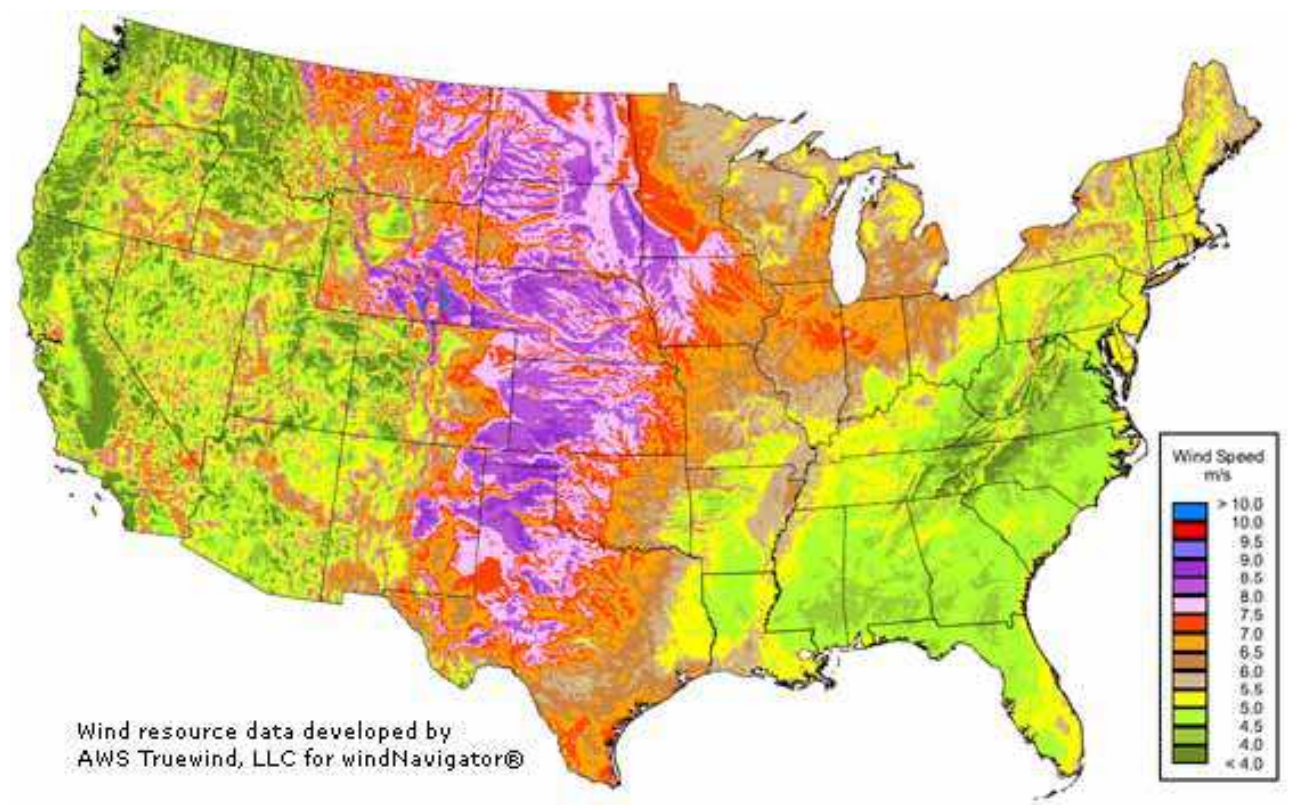

Fig. 27. WIND RESOURCE MAPT OF USA [83] United States and State - 80-Meter Wind Resource Maps

\subsection{Zeroeth aproximation calculations by Dr. Rey Sidik [84]: Methanol from the Atmosphere}

"I followed your guidelines in carrying out the following calculations.

So, the question is;

How does the cost of $1 \mathrm{Gj}$ of $\mathrm{CH} 3 \mathrm{OH}$ per Eq. [1] compare to the cost of $1 G \mathrm{Go} \mathrm{H}_{2}$ (including storage +transportation+delivery costs)?

Let's collect the thermodynamic data for the chemicals [CRC Handbook of Physics \& Chemistry, 1991]:

$\mathrm{CO}_{2}+3 \mathrm{H}_{2}=\mathrm{CH} 3 \mathrm{OH}$ (liq.) $+\mathrm{H}_{2} \mathrm{O}$ (liq.) $[1]$

at standard state:

Kcal /mol

del.G -94.25 0 -39.76 -56.68 
del.H $-94.050-57.04-68.31$

del.G for reaction $=(-56.68-39.76)-(-94.25)=-2.19 \mathrm{Kcal} / \mathrm{mol}=-9 \mathrm{Kj} / \mathrm{mol}$

del.H for reaction $=(-68.31-57.04)-(-94.05)=-31.3 \mathrm{Kcal} / \mathrm{mol}=-131 \mathrm{Kj} / \mathrm{mol}$

$\mathrm{So}$ the $\mathrm{CO}_{2}$ conversion reaction is exothermic and spontaneous at room temp. This heat was Not used in the following calculation.

Now, let's find out how many moles of $\mathrm{CH} 3 \mathrm{OH}$ gives us $1 G J$ f heat energy:

$\mathrm{CH} 3 \mathrm{OH}$ (liq.) $+32(\mathrm{O} 2)=\mathrm{CO}_{2}+2 \mathrm{H}_{2} \mathrm{O}$ (liq.) [2]

del.H -57.04 0 -94.05 -68.31

del. $\mathrm{H}$ for reaction $=2(-68.31)-94.05+57.04=-173.63 \mathrm{Kcal} / \mathrm{mol}=-726 \mathrm{Kj} / \mathrm{mol}$

1 GJ $\left[\left[726 \times 10^{\wedge}(-6)\right]=1377\right.$ moles of $\mathrm{CH} 3 \mathrm{OH}$

But, to produce 1 mole of $\mathrm{CH} 3 \mathrm{OH}$ we need 3 moles of $\mathrm{H}_{2}$.

Thus, 1 GJof methanol needs $3 \times 1377=4132$ moles of $\mathrm{H}_{2}$.

Since $1 G J$ of $\mathrm{H}_{2}$ is equivalent to 3499 moles of $\mathrm{H}_{2}\left\{1 \mathrm{GJ} /\left[285.81 \mathrm{~kJ} / \mathrm{mol} x 10^{\wedge}(-6)=3499\right.\right.$ moles $\left.\mathrm{H}_{2}\right\}$, to produce $1 G J$ of methanol, we need $4132 / 3499=1.18$ GJof $\mathrm{H}_{2}$.

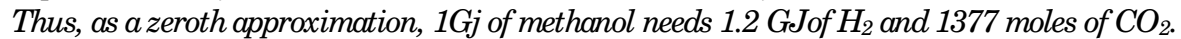
By the way, 1 GJof methanol $=1377$ moles $x 32 \mathrm{~g} / \mathrm{mol}=44 \mathrm{Kg} /$ density $=56$ liter $=15$ gallon

Now, let's calculate the air volume and diameter of the cylinder (cawl) just after the windmill that are required to CAPTURE 1377 moles of $\mathrm{CO}_{2}$ if the wind blows at $20 \mathrm{mph}$ :

$\mathrm{CO}_{2}$ concentration in the air is $0.037 \% \mathrm{v}$, using $P V=n R T, n=1.5 \times 10^{\wedge}(-5)$ moles /iter,

at $100 \%$ capture efficiency, we need an air volume of $1377 \mathrm{ln} \sim=92000$ cubic meter.

A wind of $20 \mathrm{mph}$ travels $20 x 1.6 / 12=2.7 \mathrm{~km} / 5 \mathrm{~min}$, which means this wind can form an air column of $2.7 \mathrm{~km}$ in $5 \mathrm{~min}$, so the radius of this column is what we need to find out:

Air volume $=h x$ pi $x r^{\wedge} 2$, where $r$ is the radius of column, $92000=2.7 \times 1000 \times 3.14 \times r^{\wedge} 2, r=10.85 \sim 11$ meter.

Hence, the diameter of column or cawl that is needed to supply enough $\mathrm{CO}_{2}$ to produce $1 G J$ of methanol in 5 minutes is 22 meter. This seems to be the size of a typical windmill?!

The minimum energy required to capture $\mathrm{CO}_{2}$ with $\mathrm{MgO}$ absorption is calculated as you suggested:

$\mathrm{Cp}$ [cal /K, mole]: $8.9\left(\mathrm{CO}_{2}\right), 9.0(\mathrm{MgO}), 18.0(\mathrm{MgCO} 3)$

del.H $=$ sum of Cp $x(700-300$ degree $)=(18+9+8.9) \times 400=14.36 \mathrm{Kcal} / \mathrm{mole}=60 \mathrm{Kj} / \mathrm{mole}$

to copture 1377 moles of $\mathrm{CO}_{2}$, we need $1377 x 60=83 \mathrm{Mj}=23 \mathrm{KW} . \mathrm{hr} \sim 1 \$$ worth of electricity @ 4cents $/ K w . h r$.

Thus, $\mathrm{CO}_{2}$ capture at least cost $\$ 1$ per 1 GJof methanol production, once the capital cost of equipment is paid for.

The final answer to the question of if 1GJof methanol obtained as in reaction [1] is cheaper than $1 G J H_{2}$ plus its storage+transportation+delivery cost:

$\mathrm{CO}_{2}+3 \mathrm{H}_{2}=\mathrm{CH} 3 \mathrm{OH}$ (liq.) $+\mathrm{H}_{2} \mathrm{O}$ (liq.) [1]

$1 \$ / G J$ methanol $20 \$ / G J 1.2 x 20+1=25 \$ / G J$

$M y$ conclusion from this exercise is, at the zeroth approximations of

a. $\mathrm{CO}_{2}$ capture efficiency is $100 \%$ and energy use is also close to $100 \%$ efficiency

b. $\mathrm{CO}_{2}$ conversion to methanol is $100 \%$ efficient

c. capital cost of the equipment can be recouped within short period time, say 1-2 years

d. the cost of $\mathrm{H}_{2}$ storage+transportation+delivery is about $20 \$ / G J H_{2}$ per your note"

\subsection{Useful quantities: calculations of distinguished professor Jerry North [85]}

"The current concentration of carbon dioxide is 380 ppm. I start with the air pressure that is the weight of air per square meter (100,000 Pascals). The mass is then this number divided by $\mathrm{g}=10 \mathrm{~m} / \mathrm{s}^{\wedge} 2$ or $10,000 \mathrm{~kg} / \mathrm{m}^{\wedge} 2$. 
The area of the Earth is $4.510^{\wedge} 14 \mathrm{~m}^{\wedge} 2$. So the total mass of the atmosphere is $4.510^{\wedge} 18 \mathrm{~kg}$. The molecular weight of air is $28 \mathrm{~kg} / \mathrm{kmol}$, giving us $1.610^{\wedge} 17 \mathrm{kmol}$ of air.

The number of kmoles of $\mathrm{CO}_{2}$ is then $38010^{\wedge}(-6) 1.610^{\wedge} 17+6.110^{\wedge} 13 \mathrm{kmol}$.

The molecular weight of $\mathrm{CO}_{2}$ is 44 . So we have at last $2.710^{\wedge} 15 \mathrm{~kg}$ of $\mathrm{CO}_{2}$ in the global air. And it is rising at about 0.5 percent per year.

Hence, we have about $2.710^{\wedge} 12$ metric Tonnes (1000kg) of $\mathrm{CO}_{2}$ in the air (nearly 3 trillion metric tonnes).

On the mixing of $\mathrm{CO}_{2}$ : it is well mixed vertically in the atmosphere up to many tens of km (the socalled turbopause). The mixing time from Northern to Southern Hemisphere is one to two years."

[85] These calculations came (with his permission) from Distinguished Professor cerry North (elly 2007) in the Meteorology Department of Texas A\&M University, College Station, Texas, 77843.

\subsection{A cryogenic approach}

The second suggested method is called cryogenic. In principle, it's possible to extract the $\mathrm{CO}_{2}$ from the air by passing it through a cold zone kept at temperatures a little less than that at which $\mathrm{CO}_{2}$ becomes a solid, and drops down out of the air. (77OK)

Now, the positive side is that it's a simple process thermally but it has a negative aspect to it as in trying to get the $0.03 \% \mathrm{CO}_{2}$ out of the air, we should have to cool down the air which contains it.

It's simple to make an analysis of how much this costs. I was able to come up with a zeroeth approximation for the cost of the resulting final methanol. (1 GJ).

\subsection{The electrochemical method}

The suggestion is to start off with potassium hydroxide solution, $\mathrm{KOH}$. When we pass air into $\mathrm{KOH}$, it will extract $\mathrm{CO}_{2}$ By making $\mathrm{K}_{2} \mathrm{CO}_{3}$.

Now then, we would have a solution of potassium carbonate, and if we go on passing the air at low cost (winds) through the solution until the potassium carbonate has got up to the saturation limit at which no more can be formed by passing air.

If we connect these up to a suitable power source, we will then get hydrogen off at the cathode, and $\mathrm{CO}_{2}$ off at the anode. (Oxygen will evolve with $\mathrm{CO}_{2}$ if the anode potential is positive.

This is what we need, $\mathrm{CO}_{2}$ and hydrogen. These are the elements from which we can make methanol. And so, for the moment, neglecting the fact that one has to have 3 molecules of $\mathrm{H}_{2}$, one can now proceed and make methanol by a well-known chemical process:

$$
3 \mathrm{H}_{2}+\mathrm{CO}_{2} \rightarrow \mathrm{CH}_{3} \mathrm{OH}+\mathrm{H}_{2} \mathrm{O} \text { (with CuZn catalyst) }
$$

I think that we are at the beginning of the choice of methods of removing $\mathrm{CO}_{2}$ from the atmosphere. There is a scientist at Columbia University in New York, Professor Lackner [86], who has been devoting much time to this process.

Whatever the final method, the process, direct $3 \mathrm{H}_{2}+\mathrm{CO}_{2} \rightarrow \mathrm{CH}_{3} \mathrm{OH}+\mathrm{H}_{2} \mathrm{O}$ is waiting for it, and we know we can directly go then, to the reliable electrolysis of water, producing a stream of hydrogen, and the $\mathrm{CO}_{2}$ as we have been describing. $\mathrm{CO}_{2}$ off 13

\footnotetext{
13 The other important thing is that we have to guard the potential of the anode because if two positive (or the current density are high) there will be an emission of $\mathrm{O}_{2}$ with the $\mathrm{CO}_{2}$.
} 
Under these circumstances, then, the "hydrogen economy" can be made with "liquid hydrogen" (i.e., methanol made with $\mathrm{CO}_{2}$ from the atmosphere.)

\subsection{Politics}

There will be much politics in the ratification of what we have suggested. In fact, as far as the US and the UK is concerned, both these countries house the main oil companies in the world, and it's difficult to see that there could be a change over to a new energy system without collaboration with the giant companies. There will never be a battle between two different systems. Eventually their profit-making future is to become energy companies, we may hope for collaboration and use of the minimum cost ideas that we present here.

\section{Summary}

The problem of Global Warming comes down to changing the energy production from those that produce $\mathrm{CO}_{2}$ to those that do not. (It cannot be sequestered for more than ten years.)

One cannot put a date on the time when untreated carbonaceous fuels will make it impractical to live here because this depends upon the place on the earth we are considering.

Inhabitants of the huge cold country of Canada and the enormous space left open in Siberia, would welcome unbridled Global Warming for twenty or thirty years, with the flood of people trying to escape the heat and come to somewhere where it was easier to live, they would be inundated with new inhabitants and for a while it would look as though they had made an acceptable change. However, it's obvious that finally Global Warming, if unchecked, would invade the northern areas too, and even these lands would become too hot to hold us.

Apart from the original energy which one needs, one has to think of the medium and this is where hydrogen might be regarded as the solution to a problem - no Global Warming. The problem is how to store electricity in large amounts e.g. for a city. Now, we have discussed "liquid hydrogen" and this would solve that problem too, because storing liquid hydrogen would be no different than storing oil or gasoline. Hence, methanol from the atmosphere might be the answer to hydrogen high cost.

Time is a pressing issue. The Chinese government has made the announcement that it is going to convert the transport system in China to renewables within eleven years from 2010. Meanwhile, democracies are not well known for quick decisions. This is one of the problems we shall have to face as we move closer to the vast Changes which are being made by the Chinese and which will overtake the United States within ten years, as we will have to battle not only the problem of exhausting energy and Global Warming but the competitive power of a China, rapidly building an energy supply (plus a $300 \mathrm{mph}$ train system.)

\section{References}

[1] The Hydrogen Economy. Opportunities, Costs, Barriers and R\&D Needs. National Research Council and National Academy of Engineering, National Academies Press, Washington DC, 2004.

[2] Patrick Coffey, Cathedrals of Science: The Personalities and Rivalries That Made Modern Chemistry, Oxford University Press, 2008. ISBN 978-0-19-532134-0 
[3] T.N. Veziroglu, I. Gurkan, M.M. Padki, International Journal of Hydrogen Energy, 14, 1989, 257.

[4] $\mathrm{CO}_{2}$ over 1000 years. The Hydrogen Economy. Opportunities, Costs, Barriers and R\&D Needs. National Research Council and National Academy of Engineering, National Academies Press, Washington DC, 2004; John O'M. Bockris, "Renewable Energies: Feasibility, Time, and Cost Options, Nova Science Publishers, New York, 2009.

[5] "Climate change could be accelerated by 'methane time bomb'", The Telegraph, Heidi Blake, February 22, 2010.

[6] "Methane and Carbon Monoxide in the Troposphere". http://www.atmosp.physics.utoronto.ca/people/loic/chemistry.html. Retrieved 2008-07-18.

[7] "Methane bubbles climate trouble". BBC News. 2006-09-07. http://news.bbc.co.uk/2/hi/science/nature/5321046.stm. Retrieved 2006-09-07

[8] Shakhova, Natalia; Semiletov, Igor (2007), "Methane release and coastal environment in the East Siberian Arctic shelf", eburnal of Marine Systems 66 (1-4): 227-243, doi:10.1016/j.jmarsys.2006.06.006

[9] Climate Change 2001: The Scientific Basis (Cambridge Univ. Press, Cambridge, 2001)

[10] N. E. Shakhova, I. P. Semiletov, A. N. Salyuk, N. N. Bel'cheva, and D. A. Kosmach, (2007). "Methane Anomalies in the Near-Water Atmospheric Layer above the Shelf of East Siberian Arctic Shelf". Doklady Earth Sciences 415 (5): 764-768. doi:10.1134/S1028334X07050236.

[11] Walter, Km; Zimov, Sa; Chanton, Jp; Verbyla, D; Chapin, Fs, 3Rd (Sep 2006). "Methane bubbling from Siberian thaw lakes as a positive feedback to climate warming.". Nature 443 (7107): 71-5. doi:10.1038/nature05040. ISSN 0028-0836. PMID 16957728.

[12] http://globalwarmingcycles.info/, 2010

[13] Private communications in 2009 with JOMB.

[14] Private communications with DOE and JOMB, 2009.

[15] Mapping methane emissions from a marine geological seep source using imaging spectrometry Dar A. Roberts a, $\square$, Eliza S. Bradley a, Ross Cheung b, Ira Leifer c, Philip E. Dennison d, Jack S. Margolis, Remote Sensing of Environment, 114, (2007) 592-606.

[16] T.N. Veziroglu, I. Gurkan, and M.M. Padki, International Journal of Hydrogen Energy, 14, 1989, 257.

[17] T.N. Veziroglu, I. Gurkan, and M.M. Padki, International Journal of Hydrogen Energy, 14, 1989

[18] Anthropogenic Global Warming is Nonsense, by Edward Townes $\begin{array}{llll}\text { (libertarian) Sunday, } & \text { December } & 3007\end{array}$ http:/ / www.nolanchart.com/article805.html

[19] Pelham, Brett (2009-04-22). "Awareness, Opinions About Global Warming Vary Worldwide". Gallup. http://www.gallup.com/poll/117772/Awareness-OpinionsGlobal-Warming-Vary-Worldwide.aspx. Retrieved 2009-07-14.

[20] Julio Usaola and Edgardo D. Castronuovo, Wind Energy In Electricity Markets with High Wind Penetration, Nova Science Publishers, New York, 2009.

[21] Cedrick N. Osphey (Ed), Wind Power: Technology, Economics and Policies, Nova Sciences Publishers, New York, 2009. 
[22] The Destructive Power of Wind: Turbine Disintigrates, Hank Green 25/02/08, http://www.ecogeek.org/wind-power/1396

[23] John O'M. Bockris, “Renewable Energies: Feasibility, Time, and Cost Options, Nova Science Publishers, New York, 2009.

[24] Bryan W. Roberts, David H. Shepard, Ken Caldeira, M. Elizabeth Cannon, David G. Eccles, Albert J. Grenier, and Jonathan F. Freidin, "Harnessing High Altitude Wind Power," IEEE Transactions on Energy Conversion, Vol. 22, No. 1, March 2007.

[25] John O'M. Bockris, Renewable Energies: Feasibility, Time and Cost Options, Nova Science Publishers, New York, 2009, pgs 16-21.

[26] Energy: The Solar-Hydrogen Alternative, J. O'M. Bockris, John Wiley and Sons, New York, 1975, pages 151-153.

[27] Muradov and Veziroglu private communications with them 2009. Muradov, N.Z. and T.N. Veziroğlu (2008) "Green" path from fossil-based to hydrogen economy: An overview of carbon-neutral technologies. International eburnal of Hydrogen Energy 33, 6804- 6839.

[28] John O'M. Bockris, Renewable Energies: Feasibility, Time and Cost Options, Nova Science Publishers, New York, 2009, pgs 21-23.

[29] Bryan W. Roberts, David H. Shepard, Ken Caldeira, M. Elizabeth Cannon, David G. Eccles, Albert J. Grenier, and Jonathan F. Freidin, "Harnessing High Altitude Wind Power," IEEE Transactions on Energy Conversion, Vol. 22, No. 1, March 2007.

[30] Wind Energy Fact Sheet, American Wind Energy Association 2009.

[31] Environmental Conservation, John O’M. Bockris, No. 4, Vol 2, 1975

[32] http://meted.ucar.edu/hurrican/strike/text/htc_desc.htm

[33]Wind Energy Resource Atlas, http://rredc.nrel.gov/wind/pubs/atlas/chp2.html.

[33a] Wind Energy Resource Atlas http://rredc.nrel.gov/wind/pubs/atlas/chp3.html

[34] John O'M. Bockris, Renewable Energies: Feasibility, Time and Cost Options, Nova Science Publishers, New York, 2009, pgs 22-23.

[35] Wind Energy Fact Sheet, American Wind Energy Association, 2001.

[36] Richard Heinberg, The Party's Over, New Society Publishers, Gabriola Island, 2005.

[36a] Richard Heinberg, The Party's Over, New Society Publications, 2006, p 154.

[36b] Richard Heinberg, The Party's Over, New Society Publications, 2006, p 156.

[37] Kenneth S. Deffeyes. Hubbert's Peak: The Impending World Oil Shortage, Princeton University Press (August 11, 2003), ISBN 0-691-11625-3.

[38] Richard Heinberg. The Party's Over: Oil, War, and the Fate of Industrial Societies, New Society Press ISBN 0-86571-482-7

[39] Mathew R. Simmons. Twilight in the Desert: The Coming Saudi Oil Shock and the World Economy, Wiley (June 10, 2005), ISBN 0-471-73876-X

[40] Muradov, N.Z. and T.N. Veziroğlu (2008) "Green" path from fossil-based to hydrogen economy: An overview of carbon-neutral technologies. International cburnal of Hydrogen Energy 33, 6804-6839.

[41] Kraft A. Ehricke, "The Power Relay Satellite (PRS) Concept in the Framework of the Overall Energy Picture, North American Aerospace Group, Rockwell International, December 1973. 
[42] Kraft A. Ehricke, "The Power Relay Satellite (PRS) Concept in the Framework of the Overall Energy Picture, North American Aerospace Group, Rockwell International, December 1973, pg

[43] Kraft A. Ehricke, "The Power Relay Satellite (PRS) Concept in the Framework of the Overall Energy Picture, North American Aerospace Group, Rockwell International, December 1973, pg 141, Fig 8.1.

[44] Kraft A. Ehricke, "The Power Relay Satellite (PRS) Concept in the Framework of the Overall Energy Picture, North American Aerospace Group, Rockwell International, December 1973, pg 147-149, figs 8.5, 8.6, Tables 8.3 and 8.4.

[45] Kraft A. Ehricke, "The Power Relay Satellite (PRS) Concept in the Framework of the Overall Energy Picture, North American Aerospace Group, Rockwell International, December 1973, pg 150, figs 8.7, Table 8.5.

[46] Energy: The Solar-Hydrogen Alternative, J. O'M. Bockris, John Wiley and Sons, New York, 1975, pages 151-153.

[47] AArthur Cristian, Bakken Oil Formation In Dakota/Montana Provides USA 8 Times As Much Oil As Saudi Arabia @ \$16 Per Barrel x 500 Billion Barrels Thu, 09/11/2008http://www.loveforlife.com.au/node/5492; and Rod Nickel, Harnessing the Boom, The StarPhoenix, Friday, May 09, 2008

[48] "Branson launches \$25m climate bid". BBC.co.uk. http:/ / news.bbc.co.uk/1/hi/sci/tech/6345557.stm. Retrieved 2008-04-30.

[49] "US Department of Energy on greenhouse gases". http://www.eia.doe.gov/oiaf/1605/ggccebro/chapter1.html. Retrieved 2007-10-04.

[50] "Race for millions". Cosmos Magazine. http://www.cosmosmagazine.com/features/online/1075/the-race-bransonsmillions. Retrieved 2008-11-05.

[51] From hydrocarbon to hydrogen-carbon to hydrogen economy Authors: Muradov, NZ; Veziroglu, TN, Journal: INT J HYDROGEN ENERG, 30 (3): 225-237 MAR 2005.

[52] Department of Energy Cost of Energy Section, 2010.

[53] Kenneth S. Deffeyes. Hubbert's Peak: The Impending World Oil Shortage, Princeton University Press (August 11, 2003), ISBN 0-691-11625-3.

[54] Arthur Cristian, Bakken Oil Formation In Dakota/Montana Provides USA 8 Times As Much Oil As Saudi Arabia @ \$16 Per Barrel x 500 Billion Barrels Thu,, 09/11/2008http://www.loveforlife.com.au/node/5492; and Rod Nickel, Harnessing the Boom, The Star Phoenix, Friday, May 09, 2008

[55] "Branson launches $\$ 25 \mathrm{~m}$ climate bid". BBC.co.uk. http://news.bbc.co.uk/1/hi/sci/tech/6345557.stm. Retrieved 2008-04-30.

[56] "US Department of Energy on greenhouse gases". http://www.eia.doe.gov/oiaf/1605/ggccebro/chapter1.html. Retrieved 2007-10-04.

[57] "Race for millions". Cosmos Magazine.

http:/ / www.cosmosmagazine.com/features/online/1075/the-race-bransonsmillions. Retrieved 2008-11-05.

[58] Richard Heinberg. The Party's Over: Oil, War, and the Fate of Industrial Societies, New Society Press ISBN 0-86571-482-7

[59] Mathew R. Simmons. Twilight in the Desert: The Coming Saudi Oil Shock and the World Economy, Wiley (June 10, 2005), ISBN 0-471-73876-X 
[60] From hydrocarbon to hydrogen-carbon to hydrogen economy Authors: Muradov, NZ; Veziroglu, TN, Journal: INT J HYDROGEN ENERG, 30 (3): 225-237 MAR 2005.

[61] Renewable Energy Resources, John Tidwell, Tony Weir, 2005, Taylor \& Francis Publishers.

[62] NREL Photograph and Information Exchange

[63] Council of Australian Governments, July 2006

[64] High Temperature Solar Thermal Technology, Wyld Group, February 4, 2009 (Australian Library Collection)

[65] Popular Science, November 2007

[66] Closed cycle OTEC Schematic-Ocean Thermal Energy Conversion: Possible application in Certain Pacific Island Nations, Alicia Altagracia Aponte.

[67] 2009-10-24 13:49 (UTC) Geothermie_Prinzip01.jpg Geothermie_Prinzip.svg: Geothermie_Prinzip01.jpg: "Siemens Pressebild" http://www.siemens.com derivative work: FischX (talk) Geothermie_Prinzip01.jpg: "Siemens Pressebild" http://www.siemens.com derivative work: Ytrottier This file is licensed under the Creative Commons Attribution-Share Alike 3.0 Unported license. You are free: to share - to copy, distribute and transmit the work; to remix - to adapt the work Under the following conditions: attribution - You must attribute the work in the manner specified by the author or licensor (but not in any way that suggests that they endorse you or your use of the work). share alike - If you alter, transform, or build upon this work, you may distribute the resulting work only under the same or similar license to this one.

[68] http://en.wikipedia.org/wiki/Enhanced_Geothermal_System

http://altarockenergy.com/AltaRockEnergy.2009-03-19.pdf ; MIT Report, 2009, Earth Science Deparment.

[69] http://en.wikipedia.org/wiki/Tidal_power, October 2007.

[70] :Superconductivity, Wikipedia, Free Encyclopedia, 2010.

[71] J.O'M. Bockris, “A Hydrogen Economy”, Environment, 13, 1971, 51; and History of Hydrogen Fact Sheet, The National Hydrogen Energy Association http://www.hydrogenassociation.org/general/factSheet_history.pdf

[72] P. Dandapani, Personal Income and Energy, Int. J. Hydrogen Energy, 12, 1987, 439.

[73] Tapan Bose and Pierre Malbrunot, et al, Hydrogen: Facing the Energy Challenge of the21st Century, John Libby Eurotext, UK, December 2006

[74] Wiberg, Egon; Wiberg, Nils; Holleman, Arnold Frederick (2001). Inorganic chemistry. Academic Press. p. 240. ISBN 0123526515.

http:// books.google.com/books?id=vEwj1WZKThEC\&pg=PA240.

[75] Nazim Muradov, "“Hydrogen via methane decomposition: an application for decarbonization of fossil fuels"", International Journal of Hydrogen Energy 26 (2001) pp. 1165-1175.

[76] Popular Science, November 12, 2007.

[77] Judge Bevan, S. Badwell, and J.O'M. Bockris, Evolution and Dissolution of Oxygen on Urania-Yttria, Acta Electrochimica, 25, 1980

[78] "The Methanol Economy: Beyond Oil and Gas", Olah, Goeppert \& Prakash, Wiley, 2006.

[79] http://www.iea.org/work/2002/stavanger/mhi.pdf 
[80] S. Ono, et al, "The Effect of $\mathrm{CO} 2, \mathrm{CH} 4, \mathrm{H} 20$, and N2 on $\mathrm{Mg}-\mathrm{MI}$ Alloy as hydrogen Transportation" IJHE, 11, 6, 1986, 381-387.

[81] http://www.brain-c-jcoal.info/cctinjapan-files/english/2_5A1.pdf

[82] Isamu Yasudaa and Yoshinori Shirasaki (Tokyo Gas) Development and Demonstration of Membrane Reformer System for Highly efficient Hydrogen Production from Natural Gas, Materials Science Forum Vols. 539-543 (2007) pp 1403-1408

[83] Wind Powering America, U.S. Department of Energy, http://www.windpoweringamerica.gov/wind_maps.asp

[84] Private communications with JOMB and Rey Sidik, calculations.

[85] Private communication between JOMB and Jerry North (July 2007)

[86] http:// www.columbia.edu/ kl2010/members_lackner.htm

\section{TABLES}

Table 1. Wind classes and wind speed.J. O'M. Bockris original and in John O'M. Bockris, Renewable Energies: Feasibility, Time and Cost Options, Nova Science Publishers, New York, 2009

Table 2. Power Relay Satellite Concept, Kraft A. Ehricke, “The Power Relay Satellite (PRS) Concept in the Framework of the Overall Energy Picture, North American Aerospace Group, Rockwell International, December 1973, pg 147-149, figs 8.5, 8.6, Tables 8.3 and 8.4 .

Table 3. Character of microwave PRS energy systems. Kraft A. Ehricke, "The Power Relay Satellite (PRS) Concept in the Framework of the Overall Energy Picture, North American Aerospace Group, Rockwell International, December 1973, pg 147-149, figs 8.5, 8.6, Tables 8.3 and 8.4.

Table 4. http://en.wikipedia.org/wiki/Enhanced_Geothermal_System http://altarockenergy.com/AltaRockEnergy.2009-03-19.pdf

Table 5. SOME LARGER TIDAL POWER SCHEMES UNDER CONSIDERATION AROUND THE WORLD http:/ / en.wikipedia.org/wiki/Tidal_power, October 2007.

Table 6. Critical Temperature (Tc), crystal structure and lattice constants of some high-Tc http://en.wikipedia.org/wiki/Superconductivity 2010

Table 7. Cost of Raw Hydrogen, Various conditions.

Table 8. Electricity, Methanol, and Hydrogen Compared as Fuels.

\section{FIGURES}

Fig. 1. This figure was created by Robert A. Rohde from published data and is part of the Global Warming Art project.Original image:

http://www.globalwarmingart.com/wiki/Image:Greenhouse_Effect_png It was converted to SVG by User:Rugby471.Permission is granted to copy, distribute and/or modify this document under the terms of the GNU Free Documentation License, Version 1.2 only as published by the Free Software Foundation; with no Invariant Sections, no Front-Cover Texts, and no Back-Cover Texts. A copy of the license is included in the section entitled "Text of the GNU Free Documentation License."; 1997.

Fig. 2. The Keeling Curve of atmospheric $\mathrm{CO}_{2}$ concentrations measured at Mauna Loa Observatory. Work, from Image:Mauna Loa Carbon Dioxide.png, uploaded in Commons by Nils Simon under licence GFDL \& CC-NC-SA ; itself created by Robert A. Rohde from NOAA published data and is incorporated into the Global 
Warming Art project. Permission is granted to copy, distribute and/or modify this document under the terms of the GNU Free Documentation License, Version 1.2 or any later version published by the Free Software Foundation; with no Invariant Sections, no Front-Cover Texts, and no Back-Cover Texts. A copy of the license is included in the section entitled "GNU Free Documentation License";

Fig. 3. From Tapan Bose and Pierre Malbrunot, et al, Hydrogen: Facing the Energy Challenge of the 21st Century, John Libby Eurotext, UK, December 2006, page 17.

Fig. 4. This image shows the instrumental record of global average temperatures as compiled by the Climatic Research Unit of the University of East Anglia and the Hadley Centre of the0 UK Meteorological Office. Data set TaveGL2v was used. The most recent documentation for this data set is Jones, P.D. and Moberg, A. (2003) "Hemispheric and large-scale surface air temperature variations: An extensive revision and an update to 2001". Journal of Climate, 16,206-223.

Fig. 5. The Hydrogen Economy. Opportunities, Costs, Barriers and R\&D Needs. National Research Council and National Academy of Engineering, National Academies Press, Washington DC, 2004.

Fig. 6. Mapping methane emissions from a marine geological seep source using imaging spectrometry Dar A. Roberts a, $\square$, Eliza S. Bradley a, Ross Cheung b, Ira Leifer c, Philip E. Dennison d, Jack S. Margolis, Remote Sensing of Environment, 114, 2010, pg 600.

Fig. 7a. http://www.cnsm.csulb.edu/departments/geology/people/bperry/geology303/ _derived/geol303text.html_txt_atmoscell_big.gif

Fig. 7b. http://mabryonline.org/blogs/woolsey/images/global\%20winds\%202-1.jpg

Fig. 8. Energy Center, John O’M. Bockris Original.

Fig. 9. A \& B: Energy Manual, Iowa Energy Center, 2006, www.energy.iastate.edu/renewable/wind/wem/wem-08_power.html

Fig. 10. A possible arrangement for a sea-borne generator. \{J.Bockris, 1975\} Environmental Conservation John O'M. Bockris, No. 4, Vol 2, 1975; John O'M. Bockris, Renewable Energies: Feasibility, Time and Cost Options, Nova Science Publishers, New York, 2009, pg 14.

Fig. 11. An alternative arrangement for a sea-borne generator. \{J.Bockris, 1975\} Environmental Conservation John O'M. Bockris, No. 4, Vol 2, 1975; John O'M. Bockris, Renewable Energies: Feasibility, Time and Cost Options, Nova Science Publishers, New York, 2009, pg 15.

Fig. 12. Diagram of the FEG in flight, showing the craft's nose-up angle,, , which is identical to the control axis angle,_c, as no cyclic pitch use is planned. The rotors fore and aft flapping angle, a1, is shown as the angle between the normal to the tip-path plane and the control axis. The total rotor thrust component along the control axis is T, and normal to this axis is the component force $\mathrm{H}$. If $\mathrm{T}$ and $\mathrm{H}$ forces are combined vectorally the total rotor force is almost normal to the tip-path plane $\{\mathrm{J}$. Bockris, 2009\} [25] John O'M. Bockris, Renewable Energies: Feasibility, Time and Cost Options, Nova Science Publishers, New York, 2009, pgs 16-21 and.Bryan W. Roberts, et al., "Harnessing High Altitude Wind Power, IEEE http://www.jppetit.org/ENERGIES_DOUCES/eolienne_cerf_volant/eolienne_cerf_volant.pdf pg 4.

Fig. 13. Rendering of Sky Wind Power Corp.'s planned $240 \mathrm{~kW}$, four-rotor demonstration craft \{B. Roberts, D. Shepherd, et al, 2007: [29]. Bryan W. Roberts, et al., 
“Harnessing High Altitude Wind Power, IEEE http://www.jppetit.org/ENERGIES_DOUCES/eolienne_cerf_volant/eolienne_cerf_volant.pdf, pg 2.

Fig. 14. "World map showing two mid latitude westerly wind belts (shown in pink). The northern belt blows from west to east across North America, the North Atlantic Ocean, Europe, and Asia. The southern belt blows from west to east across the South Pacific Ocean, Chile, Argentina, the South Atlantic Ocean, South Africa, the South Indian Ocean, Southern Australia, and New Zealand. The yellow arrows in the picture also show two tropical easterly wind belts blowing from east to west on either side of the equator. The northern tropical easterly belt blows across the Pacific Ocean, Southeast Asia, India, the North Indian Ocean, the Arabian Peninsula, Saharan Africa, the Atlantic Ocean, the Caribbean Sea, Southern Mexico, and Central America. The southern belt blows from east to west across Northern Australia, the Indian Ocean, Southern Africa, the South Atlantic Ocean, the middle of South America, and the South Pacific Ocean." [32]

Fig. 15. Source: GWEC, Worldwatch. Figure 15. From Wind Energy Fact Sheet, American Wind Energy Association, 2004.\{AWEA, 2001\} [35].

Fig. 16. Figure shows the great distances between areas of high insolation; and those of high concentration of affluent groups with manufacture \{Kraft-Ehricke, 1973\} [41].

Fig. 17. Power relay satellite concept \{Kraft-Ehricke, 1973\} [44].

Fig. 18. Range of a number of Primary Energy Power Plant Systems \{Kraft-Ehricke, 1973\} [44].

Fig. 19. Linear array of waveguide-fed helix elements \{J. Bockris, 1975\} [46].

Fig. 20. New presentation of data in figure 20 of http://www.hubbertpeak.com/hubbert/1956/1956.pdf. Meant as replacement for non-free en::Image:Hubbert-fig-20.png 2007-03-04 (original upload date) Transferred from en.wikipedia; transferred to Commons by User:Pline using CommonsHelper Original uploader was Hankwang at en.wikipedia CC-BY-2.5; Released under the GNU Free Documentation License http://en.wikipedia.org/wiki/File:Hubbert_peak_oil_plot.svg

Fig. 21. (a) Schematic of a power tower. Image adapted from Energy Efficiency Renewable Energy Network \{J. Tidwell, 2005\} [61];

Fig. 21. (b): Solar Two, power tower. Image courtesy of NREL's Photographic Information Exchange [62].

Fig. 22a. Schematic of a parabolic trough concentrator. Image adapted from Energy Efficiency Renewable Energy Network \{Council of Australian Governments, 2006\} [63].

Fig. 22b. Trough concentrator system at the Australian National University, which is designed to incorporate photovoltaic power generation or water heating and steam production. (Image courtesy of the Centre for Sustainable Energy systems, Australian National University, \{Wyld Group, 2009\} [64].

Fig. 23. Schematic of Closed-cycle OTEC system. Closed cycle OTEC Schematic-Ocean Thermal Energy Conversion: Possible application in Certain Pacific Island Nations, Alicia Altagracia Aponte [66].

Fig. 24. Diagram of EGS with numeric labels. 1:Reservoir 2:Pump house 3:Heat exchanger 4:Turbine hall 5:Production well 6:Injection well 7:Hot water to district heating 
8:Porous rock $\quad$ 9:Well $\quad$ 10:Solid bedrock. $\quad$ 2009-10-24 13:49 (UTC) Geothermie_Prinzip01.jpg Geothermie_Prinzip.svg: Geothermie_Prinzip01.jpg: "Siemens Pressebild" http://www.siemens.com derivative work: FischX (talk) Geothermie_Prinzip01.jpg: "Siemens Pressebild" http://www.siemens.com derivative work: Ytrottier This file is licensed under the Creative Commons Attribution-Share Alike 3.0 Unported license. You are free: to share - to copy, distribute and transmit the work; to remix - to adapt the work Under the following conditions: attribution - You must attribute the work in the manner specified by the author or licensor (but not in any way that suggests that they endorse you or your use of the work). share alike - If you alter, transform, or build upon this work, you may distribute the resulting work only under the same or similar license to this one [67].

Fig. 25. P. Dandapani, Personal Income and Energy, Int. J. Hydrogen Energy, 12, 1987, 439.

Fig. 26. Tapan Bose and Pierre Malbrunot, et al, Hydrogen: Facing the Energy Challenge of the21st Century, John Libby Eurotext, UK, December 2006, p.59.

Fig. 27. Wind Powering America, U.S. Department of Energy, http://www.windpoweringamerica.gov/wind_maps.asp 


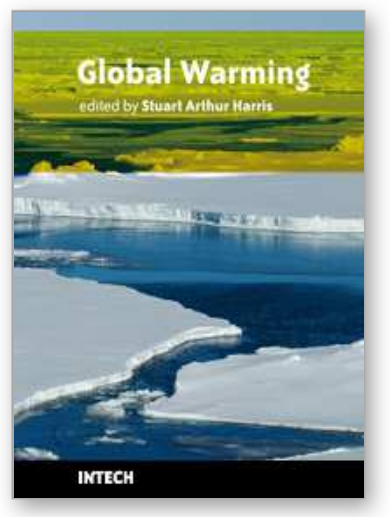

\author{
Global Warming \\ Edited by Stuart Arthur Harris
}

ISBN 978-953-307-149-7

Hard cover, 250 pages

Publisher Sciyo

Published online 27, September, 2010

Published in print edition September, 2010

This book is intended to introduce the reader to examples of the range of practical problems posed by "Global Warming". It includes 11 chapters split into 5 sections. Section 1 outlines the recent changes in the Indian Monsoon, the importance of greenhouse gases to life, and the relative importance of changes in solar radiation in causing the changes. Section 2 discusses the changes to natural hazards such as floods, retreating glaciers and potential sea level changes. Section 3 examines planning cities and transportation systems in the light of the changes, while section 4 looks at alternative energy sources. Section 5 estimates the changes to the carbon pool in the alpine meadows of the Qinghai-Tibet Plateau. The 11 authors come from 9 different countries, so the examples are taken from a truly international set of problems.

\title{
How to reference
}

In order to correctly reference this scholarly work, feel free to copy and paste the following:

John Bockris (2010). Global Warming, Global Warming, Stuart Arthur Harris (Ed.), ISBN: 978-953-307-149-7, InTech, Available from: http://www.intechopen.com/books/global-warming/global-warming-

\section{INTECH}

open science | open minds

\section{InTech Europe}

University Campus STeP Ri

Slavka Krautzeka 83/A

51000 Rijeka, Croatia

Phone: +385 (51) 770447

Fax: +385 (51) 686166

www.intechopen.com

\section{InTech China}

Unit 405, Office Block, Hotel Equatorial Shanghai

No.65, Yan An Road (West), Shanghai, 200040, China

中国上海市延安西路65号上海国际贵都大饭店办公楼405单元

Phone: +86-21-62489820

Fax: +86-21-62489821 
(C) 2010 The Author(s). Licensee IntechOpen. This chapter is distributed under the terms of the Creative Commons Attribution-NonCommercialShareAlike-3.0 License, which permits use, distribution and reproduction for non-commercial purposes, provided the original is properly cited and derivative works building on this content are distributed under the same license. 